Portland State University

PDXScholar

1994

\title{
A Study of Community College Instructional Stakeholder Attitudes Toward Student Outcome Goals
}

Linda Ann Gerber

Portland State University

Follow this and additional works at: https://pdxscholar.library.pdx.edu/open_access_etds

Part of the Educational Administration and Supervision Commons Let us know how access to this document benefits you.

Recommended Citation

Gerber, Linda Ann, "A Study of Community College Instructional Stakeholder Attitudes Toward Student Outcome Goals" (1994). Dissertations and Theses. Paper 1275.

https://doi.org/10.15760/etd.1274

This Dissertation is brought to you for free and open access. It has been accepted for inclusion in Dissertations and Theses by an authorized administrator of PDXScholar. Please contact us if we can make this document more accessible: pdxscholar@pdx.edu. 
A STUDY OF COMMUNITY COLLEGE INSTRUCTIONAL STAKEHOLDER ATTITUDES TOWARD STUDENT OUTCOME GOALS

\author{
by \\ LINDA ANN GERBIER
}

A dissertation submitted in partial fulfillment of the requirements for the degree of

\author{
DOCTOR OF EDUCATION \\ in \\ EDUCATIONAL LEADERSHIP: \\ POSTSECONDARY EDUCATION
}

Portland state University

01994 


\section{DISSERTATION APPROVAL}

The abstract and dissertation of Iinda Ann Gerber for the Doctor of Education in Educational Leadership:

Postsecondary Education were presented May 3, 1994, and accepted by the dissertation committee and the doctoral program.

COMMITEE APPROVALS:

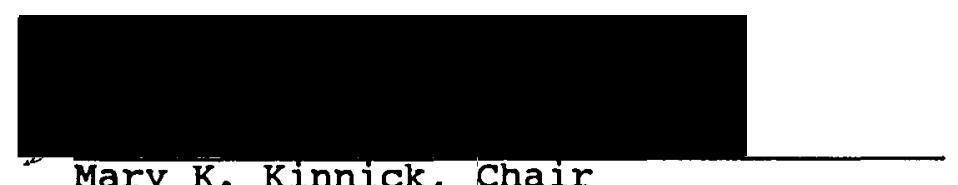

Mary K. Kinnick, Chair

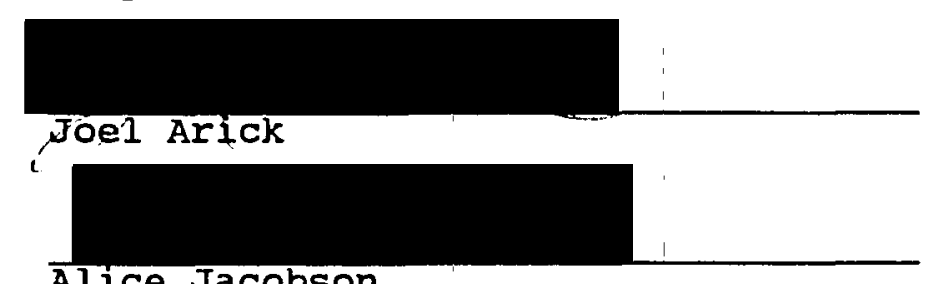

Alice Jacobson

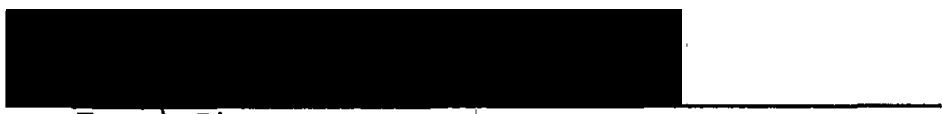

Joan Strouse

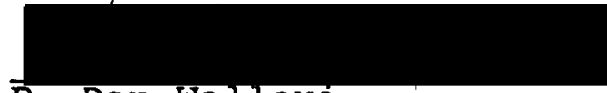

R. Dan Walleri

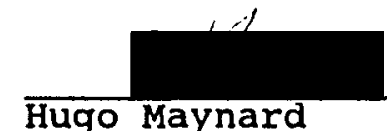

Representative of the office of Graduafte Studies

DOCTORAL PROGRAM APPROVAL:

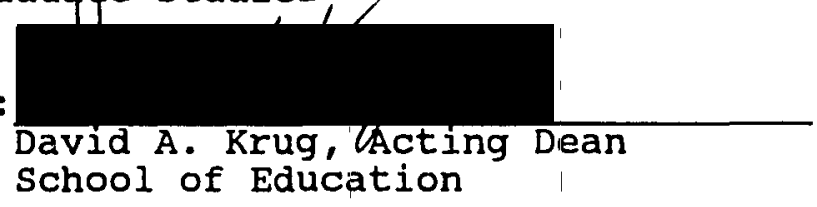

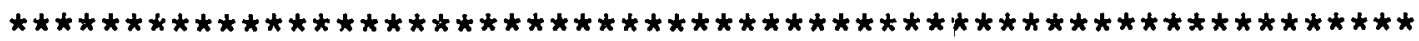
ACCEPTED FOR PORTLAND STATE UNIVERSITY BY THE LIBRARY

by

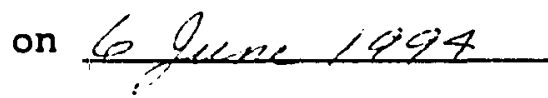




\begin{abstract}
An abstract of the dissertation of Linda Ann Gerber for the Doctor of Education in Educational Leadership: Postsecondary Education presented May 3, 1994.

Title: A Study of Community college Instructional Stakeholder Attitudes Toward Student outcome Goals
\end{abstract}

This study sought to determine the importance community college instructional stakeholders--teachers, administrators, and support staff--ascribe to 23 student outcome goals and to examine the relationships between biographical variables and stakeholders' perceptions. The study addressed the following research questions: (a) Which of the 23 student outcomes do instructional stakeholders as a whole perceive to be most important?; (b) Can these outcomes be factored into a set underlying constructs?; (c) Does the perceived importance of student outcomes vary in relationship to the type of student the stakeholder serves?; (d) Which outcomes do stakeholders serving different types of students value most highly?; (e) Does the perceived importance of student outcomes vary in relationship to: professional role, number of years worked 
in a community college, number of years worked at the community college surveyed, campus assignment, and gender?

Data were collected from 241 subjects employed by a large, urban community college. subjects rated the importance of 23 student outcomes on a Likert-like scale. The student outcome Goals Inventory, a survey instrument developed by the researcher, was used to collect data.

Data were analyzed using one or more of the following statistical tests where appropriate: ANOVA, $\underline{t}$ Test, Factor Analysis, and Discriminant Function Analysis. The major conclusions drawn from this study were: (a) Instructional stakeholders as a group perceived outcomes related to affective constructs, basic skills development, and goal setting to be most important; (b) six constructs represent the outcomes (Personal/Social, Transfer, Credentialing, Employment, Traditional College, and Developmental); (c) Type of student served has a significant relationship to the perceived importance of 12 of the 23 outcomes with most differences occurring between stakeholders serving lower division transfer students and those serving professional/technical students; (d) Few significant relationships exist between the remaining biographical variables and the 23 outcome variables; (e) The type of students stakeholders served can be predicted with 698 accuracy. The outcomes rated most highly by stakeholders are those that represent a foundation of skills that 
students are typically expected to gain in their secondary education. 
To my parents,

Harry and Betty Gerber, who have always believed in the value of education, and to the memory of my great grandmother, olive Tracy, who believed in me. 


\section{ACKNOWLEDGFMENTS}

For their constant support, I feel a deep sense of gratitude to my family. My children, Tracy, Jason, Jordan, and Rainy (Rose) Christensen gave me the sense of purpose that started me on the path of higher education and led to this achievement. over the years, their demonstrations of love have kept me afloat. My husband, Charles Christensen, has lovingly and patiently traveled with me on this journey. For this I am thankful.

The work that this dissertation represents would not have been completed without the expertise and support of my committee, Dr. Mary Kinnick, Dr. Alice Jacobson, Dr. Dan Walleri, Dr. Joel Arick, Dr. Joan Strouse, and Dr. Hugo Maynard. Special thanks go to Dr. Kinnick, who kept me moving in the right direction with enthusiasm and good humor. When my interest and courage flagged, Dr. Jacobson reached out to give me encouragement and in the process became a valued friend.

I am grateful to my many friends and colleagues who listened patiently to the ideas I explored and gave me feedback and encouragement as my work evolved. I am particularly indebted to Dr. Gary Nave for his excellent teaching when it came time for me to learn advanced statistics and to Nancy (Pinky) Dale who gave me invaluable 
support in the final months of this project. Two friends, Deborah Atkinson and Gert Bernstein, guided me emotionally through the tough days, and there were a few. Without their friendship I would still be writing instead of enjoying the fruits of my labor. To them I can only say a heartfelt thanks. 
TABLE OF CONTENTS

PAGE

ACKNOWLEDGEMENTS . . . . . . . . . . . . . . . . ii

LIST OF TABLES . . . . . . . . . . . . . . . . . vii

LIST OF FIGURES . . . . . . . . . . . . . . . . . . . $\mathrm{x}$

CHAPTER

I. INTRODUCTION . . . . . . . . . . . . 1

Rationale for the study:

Research Questions . . . . . . . 17

Significance of the study . . . . . . 19

Definition of Terms . . . . . . . . 21

II REVIEW OF THE LITERATURE . . . . . . . . . 24

Introduction . . . . . . . . . . . 24

Historical Background of the student
Outcomes Assessment Movement . . . . 26

The Emergence of the Assessment Movement

State Mandates for Assessment

Accrediting Association Standards

Assessment Programs at

Two-year Institutions

The Problem of Identifying

Appropriate Outcomes to Assess . . . 38

Selecting Outcomes to Assess

Organizational Behavior: Implementing

Change in Educational Institutions . . 48

Organizational Development Theory 
Strategic Planning and Program

Evaluation: stakeholder Participation

in Two Change Strategies .. . . . . 58

strategic Planning

Educational Evaluation

Summary of the Review of the Literature . 66

III DESIGN OF THE STUDY . . . . . . . . . . 68

Research Design . . . . . . . . . 68

Research Variables . . . . . . . 73

Subjects . . . . . . . . . . . . 74

Response Rate . . . . . . . . . 75

Characteristics of Respondents by

Independent Variable . . . . . . . . 77

Student Groups Served by Respondents

Professional Role of Respondents

Number of Years Worked in Community Colleges

Number of Years Worked at Sunrise Community College

Campus Location of Respondents

Gender of Respondents

Research Site . . . . . . . . . . 84

Description of Campuses

Survey Instrument . . . . . . . . . 89

Construction of the Survey

Instrument

Validity . . . . . . . . . . . 90

Reliability . . . . . . . . . . 94

Data Gathering Procedures . . . . . 96

Statistical Design . . . . . . . . . 97

IV

RESULTS . . . . . . . . . 102

Introduction . . . . . . . . . . 102 
Findings . . . . . . . . . . 103

Research Question 1

Research Question 2

Research Question 3

Research Question 4

Research Question $5 a$

Research Question 5b

Research Question 5c

Research Question 5d

Research Question $5 e$

Summary . . . . . . . . . . . 169

CONCLUSIONS . . . . . . . . . . . 171

General Conclusions . . . . . . . 171

Conclusions Related to the Research

Questions . . . . . . . . . . 175

Research Question 1

Research Question 2

Research Question 3

Research Question 4

Research Question $5 a$

Research Question 5b

Research Question 5c

Research Question 5d

Research Question $5 e$

Measuring the Foundation Skills--

Recommendations . . . . . . . 206

Limitations . . . . . . . . . 210

Recommendations for Further study . . 212

summary . . . . . . . . . . . . 214

REFERENCES • . • . . . . . . . . . . . . . 216

APPENDICES

A STUDY OUTCOME GOALS INVENTORY QUESTIONNAIRE AND COVER . • . . . . . 229

B RESULTS OF ONE-WAY ANALYSIS OF VARIANCE AND $t$ TEST FOR FACTORS • . . 234 


\section{LIST OF TABLES}

TABLE

PAGE

1.

Types of student Outcomes Assessments Performed at Postsecondary

Institutions . . . . . . . . . . . 38

2 .

NCHEMS' Type-of-Outcome Dimensions . . . 40

3.

Astin's Taxonomy of student Outcomes . . . 42

4 .

Response Rate of Population Surveyed

By Campus Location and Gender . . . . 76

5.

Respondents by student Groups

Served Most Often . . . . . . . 77

6. Respondents by Professional Role . . . 78

7. Respondents Not in Dual or other

Professional Roles... . . . . . 79

8. Respondents by Number of Years

Worked in Community Colleges . . . . 80

9. Number of Years Respondents Worked

in Community Colleges by Category . . . 81

10. Respondents by Number of Years Worked

at SCC... . . . . . . . . . . 82

11. Number of Years Respondents Worked at SCC by Category . . . . . . . . 83

12. Respondents by Campus . . . . . . . 84

13. Gender of Respondents . . . . . . . 84

14. SCC Student Headcount by Mission Area in 1990-1991... . . . . . . . . . 86

15. SCC student FTE by Campus in 1990-1991 . 87

16. Coefficients of Correlation and Coefficient Alpha for the student

Outcome Goals Inventory . . . . . . 95 
17.

18.

19.

20 .

21.

22.

23.

24.

25.

26.

27.

28.
Distribution of Survey Questionnaires by Campus Location and Gender . . . . 97

Summary of the Dependent Variables for which ANOVAs and $t$ Test Found statistically significant Differences

Means, Standard Deviations, and Ranges for All Respondents on the student Outcome Goals Variable . . . . . . 109

Factor Analysis of student outcome Variables . . . . . . . . . . 113

Analysis of Variance for student Outcome Goals between Groups Based on Type of student Served . . . . .

Scheffé Multiple Range Test of Differences Between Means for the Independent Variable Type of student Served . . . . . . . . . . . . . .

Standardized Discriminant Function Coefficients . . . . . . . . . .

Eigenvalues for the Discriminant Functions . . . . . . . . . . .

statistical significance for the Discriminant Functions . . . . . . 136

Classification Results: Number and Percent ố Predicted Cases Ässigned to the Type of student Served Subgroups . . . . . . . . . . .

Analysis of Variance for Student Outcome Goals between Groups Based on the Professional Role. . . . .

Scheffe Multiple Range Test of Differences Between Means for the Independent Variable Professional Role................. 146

Analysis of Variance for student Outcome Goals between Groups Based on the Number of Years Worked in a Community College . . . . . . . . 
30 .

31.

32 .

34 .

36.

37.

38.

40.

Scheffé Multiple Range Test of Differences Between Means for the Independent Variable Number of Years Worked in a Community College . . . .

Analysis of Variance for student Outcome Goals between Groups Based on the Number of Years Worked at SCC .

Scheffé Multiple Range Test of

Differences Between Means for the Independent Variable Number of Years Worked at SCC

Analysis of Variance for student Outcome Goals between Groups Based on the Campus Location . . . . . . 161

$t$ Test Comparison of Means for student Outcome Goals Based on Gender ...

Effectiveness Domains and student Outcome Goals . . . . . . . . .

Student Outcome Goals for which Differences Were Found: Type of student Served . . . . . . . . .

Student outcome Goals for which Differences Were Found: Professional Role . . . . . . . .

Student Outcome Goals for Which Differences Were Found: Number of Years Worked in Community Colleges . . . . . . . . . . .

Student outcome Goals for which Differences Were Found: Number of Years Worked at SCC . . . . . . . 204

Student outcome Goals for which Differences Were Found: Gender . . . 206 


\section{LIST OF FIGURES}

\section{FIGURE}

1.

Factors Explaining the Effectiveness of Planned Change Efforts . . . . . 50

2. Outcome Goals for the Whole Group Means Ranked in Descending order . . . 177 
CHAPTER I

\section{INTRODUCTION}

Student outcomes are the knowledge, skills, attitudes and behaviors that result from students' educational experiences. Nationally, external pressure on all postsecondary institutions to assess student outcomes has steadily grown over the past decade. Federal legislation, accrediting standards, and mandates by governing bodies are requiring outcomes assessment for purposes of accountability and program improvement. In addition, in many states two factors--restricted funding for public schools and reform of the public education systems--have combined to increase the demand that community colleges implement student outcomes assessment to demonstrate and improve their ability to achieve specific student outcomes. Responding to this pressure, many of the community colleges have already or are in the process of adopting student outcome goals for their institutions.

In the face of this growing pressure and activity, legitimate questions exist as to the impact such mandates will have on teaching and learning in community colleges. organizational development and change theory holds that organizational goals are more likely to be achieved if they 
are supported by the members of the organization. In community colleges, teachers and instructional administrators are the organizational participants who make daily program, curriculum, and instructional decisions. These are the workers who are/responsible for achieving mandated outcome goals and who ultimately control the quality and degree of effort employed to achieve the goals. In order for outcomes assessment mandates to have the desired impact on improving actual outcomes, there should be a positive relationship between the outcomes valued by such practitioners and those mandated by government entities or adopted by individual institutions.

There is, however, little research regarding the extent to which the teaching faculty or instructional administrators in community colleges support specific outcome goals whether mandated by external sources or constructed by the institution. A need exists to investigate the perceptions of community college faculty and instructional administrators related to the student outcomes they value. The results of such a study will inform our understanding of the outcomes valued and supported by these practitioners and of whether current outcomes assessment mandates are likely to be supported by them.

Astin (1970, 1974, 1982, 1985) was among the earliest critics of these traditional methods of determining quality. Charging that the above criteria failed to scrutinize one of 
college's primary roles, fostering student learning, he called for redefining quality and excellence in terms of an irstitution's ability to promote learning. Ewell (1984) Also championed this point of view in his influential work The Self-Regarding Institution: Information for Excellence. He asserted:

Institutional efforts to achieve excellence must first be informed by an attempt to define excellence from within the distinctive environment and perspective of each institution. They must secondly be grounded in an attempt to assess the attainment of excellence through an explicit, systematic, and participatory examination of educational outcomes. (p. 9)

student learning and development in postsecondary institutions came to be called student outcomes. The notion that these outcomes can be defined and measured, called student outcomes assessment, was soon embraced by many in higher education as a means of improving institutional effectiveness (Astin, 1985; Boyer, Ewell, Finney, \& Mingle, 1987; Daughdrill, 1988; Elman, Lynton, \& McCormack, 1985; Ewell, 1984, 1986; Fincher, 1984; Halpern, 1987; Henry, 1986; Southern Regional Education Board, 1985). These educators claimed student outcomes assessment would determine whether students are achieving in cognitive, behavioral and/or affective domains as a result of their experiences in our colleges and universities. Systematic use of outcomes assessment information would serve as a quality control mechanism, ensuring the integrity of postsecondary degrees; thus, improving an institution's 
curriculum, instructional delivery and student support services.

since these early reflections on student outcomes as measures of effectiveness, pressure to assess student outcomes in community college has continued to grow. All accrediting agencies now include outcomes assessment in their accreditation criteria (U.S. Department of Education, 1987), and 40 of the 50 states have mandated some type of student outcomes assessment for their public, postsecondary institutions (E1-Khawas, 1991).

Nationally, two recently enacted laws require community colleges to assess student outcomes. The first of these laws, The student Right-to-know and Campus security Act, Public Law 101-542, requires each community college receiving federal financial aid dollars to disclose to potential students information about the college's completion rate for their total full-time, first-time, freshman student population as well as for their student athletes receiving athletically related aid (U.S. Department of Education, 1990b): For the purposes of this law, community college completion is defined very narrowly as either graduation from a one- or two-year degree or certificate program or transfer to a four-year baccalaureate degree granting institution.

The second law, the Carl D. Perkins Vocational and Applied Technology Education Act, Public Law 101-342, 
requires that states employ accountability systems which have student outcome based performance standards and measures for two-year college professional/technical education programs which are receiving Carl Perkins development funds (U.S. Department of Education, 1990a). This act requires states to employ at least two measures to gauge community college effectiveness. The first must be a measure or set of measures of learning and competency gains that includes basic and advanced academic skills. The second must be one of the following: (a) competency attainment, (b) job or work skij.l attainment, (c) retention in school, or (d) placement in further education (National Center for Research in Vocational Education [NCRVE], 1993). A survey of the states in the summer of 1991 found that 30 states went beyond this minimum requirement and planned to develop four or more measures. Seven states planned to use seven or more measures, while only two states planned to use only the minimal two measures (Hoachlander \& Rahn, 1992). Also on the national level, the National Center for Education statistics (NCES) has been charged with developing a system to measure the abilities of college graduates to communicate effectively, to think critically, and to solve problems. This enterprise is a response to National Education Goal Five aimed at educating citizens to compete in the global economy (U.S. Department of Education, 1992). At present the NCES National Education Goals Panel has 
completed the task of identifying specific speaking and listening, reading and writing, and problem solving and critical thinking skills it deems necessary for a college graduate to operate successfully in the workplace and as a citizen. The panel has contracted with researchers at the Center for the study of Higher Education at Pennsylvania State University to define these skills more precisely beginning this year. Simultaneously, the National Center for Higher Education Management Systems (NCHEMS) will inventory current approaches to assessing these sikills. In workshops and meetings convened by the panel, postsecondary faculty have expressed appreciable concern about the national goals project. This concern is primarily focused on the potential for goals to be transformed into national standards which could, in turn, impinge on academic freedom and institutional individualism. Notwithstanding these concerns, NCES plans to complete the final design of the assessment project and implement an initial assessment between 1996 and 2000 (Corrallo, 1993).

Community colleges across the country have responded to this growing pressure to assess (Johnson, Prus, Andersen, \& El-Khawas, 1991). In 1989, the American Association of Community and Junior Colleges surveyed 675 two-year institutions (Cowart, 1990). Sixty-one percent reported that they assessed academic and/or employment outcomes and used the results to measure institutional effectiveness. 
Respondents reported that they expected the use of student outcomes assessment to increase over the next three to five years. In a 1992 survey conducted by the clearinghouse for Higher Education Assessment Instruments, 237 community colleges reported on their assessment activities (Bradley, Draper, \& Pike, 1993). Ninety-five percent of these reported that they had an assessment program in place; however, only $10 \%$ characterized these programs as established. Eighty-five percent acknowledged that they had only begun planning and implementing their programs.

Several community colleges now formally publish student outcomes as indicators of their institutional effectiveness. A context analysis of documents submitted to the Educational Resources Information Center (ERIC) from 1985 to the present disclosed that the following outcomes were employed by one or more of the institutions: (a) attrition/retention of students, (b) course attendance, (c) course completion, (d) completion of certificate or degree at community college, (e) student mastery of general education competencies, (f) achievement of student identified goals, (g) achievement of student development goals, (h) alumni transfer to senior institutions, (i) success of transfer students at senior institutions measured by grade point average (GPA), (j) success of transfer students at senior institutions measured by completion of bachelor degrees, (k) alumni transfer to another community college, (1) pass rate of professional/ 
technical completers on licensing and accrediting examinations, (m) employment of completers, (n) employment of non-completers, (0) employer satisfaction with graduates, (p) for completers, relationship of type of employment to type of postsecondary education, (q) for non-completers, relationship of type of employment to type of postsecondary education, (r) alumni satisfaction with education, and (s) student satisfaction with education (Alexander, Taylor, Karnitz, \& Flermoen, 1990; California Community Colleges AB 1725 Accountability Task Force, 1990; Edmunds, Gwynn, Hanieski, \& Herder, 1990; Hudgins, 1990; Northern Virginia Community College, 1992; Oroman, 1985; Roberts, 1986).

In the state where the study reported in this document was conducted, community colleges have been directly affected by the national trends toward assessment. They began disseminating student Right-to-know data July 1, 1993. In response to the Carl Perkins assessment mandate, the state has adopted five measures of student outcomes as indicators of effective professional/technical programs. These include: (a) enrollment in professional/technical programs, (b) satisfactory progress, (c) completion of professional technical programs, (d) employment in the field of study, and (e) completion of required certification examinations. In addition to going beyond the minimal two measures mandated by the act, the state has broadened the scope of programs affected by these standards and measures 
to include all community college professional technical programs in the state--not just those receiving Perkins' funds.

In addition to these responses to federal mandates to assess, the state where this study was conducted has legislated the Educationail Act for the 21st century (HB 3565) (Oregon Department lof Education, 1993). This law imposes additional requinements for outcomes assessment in the community college, Fiassed in 1991 by the state legislature, the law aims to make the state's youth the best educated in the nation by the year 2000 and the state's workforce equal to any in the world by 2010. A key feature of this plan eliminates the current high school diploma and replaces it with two certificates of mastery which will be awarded when students can document competencies in a preestablished set of skills and knowledge. These competencies are to be "prescribed student outcomes covering both skills and substance with high performance standards and scoring criteria" (League of Women Voters, 1993, p. 7).

The first certificate, called the certificate of Initial Mastery (CIM), will normally be earned at the end of the tenth grade. Demonstration of seven general skil.1s, such as manipulating \$ymbiol systems and understanding the literal and implied meaning of information, are required to earn the CIM. The CIM is to be in place statewide by 19961997. The details relateid to the community college's 
involvement in providing CIM level education is currently being worked out. It is clear, however, that high school students will be able to utilize community colleges to earn this certificate (Oregon Department of Education, 1993). The second certificate, the certificate of Advanced Mastery (CAM), may be earned by attending one of the state's community colleges (League of Women Voters, 1993, pp. 8-9). The CAM has as its purpose to certify that its holders have acquired competencies| to enable them to complete college degrees, apprenticeships, or skilled employment. The CAM will replace the current time and credit based calculation for high school completion with a rigorous and outcome based program, which like the CIM, requires demonstration of the competencies students have achieved. students may acquire their CAM education in one or a combination of three settings--the high school classroom, industrial/business sites, and the community college. The general skills certified by the CM Mill include: (a) applying, transferring, and increasing previously acquired knowledge and skills to new occupational $\mid$ and life roles, (b) demonstrating positive behaviors, (c) respecting diversity, (d) using systems and/structures, (e) participating in group decision-making, (f) using data to communicate, (g) using resources to accomplish goals, (h) applying technology for personal and occupational purposes, and (i) supporting the 
development of others. The CAM will be implemented statewide by 1997 (Oregon Department of Education, 1993). While the local high school district will have the primary responsibility for CAM students, the community college will be an active partner in providing many students with at least part of their CAM training. As a result, colleges will be required to coordinate their academic and professional technical programs with the high schools' CAM programs. Appreciable emphasis will be placed on assessing the competencies or outcomes required for this certificate. In this state, a funding crisis in the state's public education institutions has been created by the fact that there is no sales tax and voters recently passed an initiative ballot measure limiting the assessment of property taxes. The result has been competition between community colleges, $\mathrm{K}-12$ districts and the state system of higher education (which does not include community colleges) for shares of a shrinking general fund. It is quite possible that legislators will begin to base postsecondary school funding decisions, at least in part, on evidence of student outcomes. Also, it is likely that additional assessment mandates will be imposed by a legislature struggling to make hard decisions about educational appropriations in the face of little hard data about the effectiveness of education programs in all sectors. 
This mounting pressure to assess student outcomes has raised concerns among educators about its impact. Primary among these concerns is the problem of selecting appropriate outcomes which will genuinely reflect the educational role of the community college. Any set of outcomes measures which will be used for purposes of accountability and which has the potential of affecting resource allocation must reflect the dimensions of student learning and development that the institution intends to foster (Ewell, 1987a). If this is not the case, the measures will not be valid indicators of effectiveness.

Research in the fields of organizational change and development, education evaluation, and strategic planning consistently point to the importance of selecting outcomes that genuinely reflect the goals of the institution.

But the appropriate role or mission of the community college is one that has generated heated debate for decades. Cross: (1990) depiction of the community college mission reflects the complexity of purpose that makes identifying a comprehensive universal set of outcomes criteria difficult for many two-year colleges:

The comprehensive community college comes closer than anything in the history of education to responding to the multiple and continuous learning needs of local communities. It is a first chance institution for thousands of first-generation students. It is a second chance institution for those who have done poorly in school or on the job or who wish to change jobs or the direction of their lives. It is, for many people, an onlychance institution. They must look to the local 
community college as the only adult learning institution prepared to meet their needs as life circumstances change . . . Today's community colleges are held together by carefully balanced tensions between, for example, service to young people just starting out, mid-life career changers, and older citizens seeking satisfaction in learning itself. (p. 6)

Such complexity and diversity clearly complicates any effort to select outcomes that genuinely reflect the intentions that the institution has for the learning and development of its students.

Indeed, the disparate range of views on what constitutes the "right" role for the community college is evident in the writings of its critics. Many early critics clearly believed that the transfer function was most important and that introducing professional/technical programs into the curriculum constituted a systematic process for keeping poor and lower middle class students out of senior institutions which these critics viewed as the success pipeline (Bowles \& Gintis, 1976; Clark, 1960; Karabel, 1972, 1974; Nasaw, 1979; Pincus, 1980; Zwerling, 1976). Support for the transfer function has persisted in recent criticism (Brint \& Karabel, 1989). If such disagreement about the appropriate goals for community colleges exist among scholars of postsecondary education, it is likely that similarly disparate yiews exist among practitioners in these institutions, The underlying questions raised by these criticisms is this: what is the mission of the community college and what should it be? 
It is likely that instructional stakeholders in the community college hold similarly strong views about its mission. Most likely, those in leadership positions could generate anecdotal evidence that some instructional stakeholders believe that the appropriate mission is to educate transfer students, while others see the primary mission to be the production of well-prepared workers, and yet others believe the most important role is the social service role that includes developing minimal concrete (basic) skills. While these differences among instructional stakeholders may be demonstrated anecdotally, research does not exist in the literature that empirically explores this issue.

This lack of evidence regarding stakeholder beliefs is important in view of the fact that a common theme in the literature holds that instructors and instructional administrators should contribute appreciably to the process of identifying student outcome goals (Altieri, 1990; Astin, 1991; Banta, 1988; Erwin, 1991; Ewell, 1984; Halpern, 1987; Heany, 1990; Nichols, 1991; Yost, 1991). Yost (1991)|summed up the rationale behind this widespread recommendation. Both faculty and administrators, he stated, must agree to the validity of the goals, believe the goals | represent both their own best interests and those of the institution as a whole, and accept the need to work toward accomplishment of the goals . . . I Without broad-based involvement and acceptance the results will go unused. (p. 48) 
Yost's (1991) exhortation is persuasively supported by the organizational development literature that emphasizes the importance of organizations gaining stakeholder buy-in of goals if those goals are to be met. (See Chapter II for an extensive discussion of this concept.) Toombs and Tierney (1991) point out that in colleges:

the stakeholders and actors are individual faculty members with students as implicated bystanders. The province of individual faculty members' control over courses has the qualities of a sacred right. (p. 61)

They go on to argue that in American colleges, the curriculum resides in the course, that the course is viewed by the faculty "as the fundamental unit of practice in the teaching and learning domain and the basic building block of the curriculum" (Toombs \& Tierney, 1991, p. 29). The faculty member has dominion over changes at the course level and, consequently, over changes in the curriculum that will result in achieving specific student outcomes.

Toombs and Tierney (1991) clarify this point further, distinguishing the legitimation of goals in higher education institutions from those in other types of organizations:

The process of establishing acceptance lof change in an organization], a condition of mutual trust, a willingness to comply is usually emphasized in discussions of governance and organizational behavior - . In governance, legitimacy could spring from cultural values, acceptance of the social structure, or designation by a legitimate agent. . . In the setting of the curriculum, the compliance of governance is replaced by engagement, by joining up. The process is variously referred to as 'buying in' or 'taking ownership' or 'commitment,' but the core idea is the 
same. It signifies substantive as well as symbolic participation [underlining added]. (pp. 60-61)

Despite these recommendations to establish stakeholder buy-in, little is known about the attitudes and values held by instructional stakeholders regarding student learning and development outcomes. In their extensive 1991 review of the literature of outcomes assessment, covering 2,525 items, Welker and Morgan were struck by what they termed "an almost compulsive preoccupation with measurement without objective or substantive research to determine what is to be measured" (p. 37). They concluded that the outcome goals extant in the literature evolved from a "management science" theory and that what little research had been done to determine what should be measured took the form of surveys of administrators. The authors suggest these administrators have a vested interest in selecting outcomes that reflect positively on their institution. overwhelmingly, they found that most taxonomies of outcomes were based on opinions of authors of the articles extolling given sets of outcomes, rather than based on research of the opinions of faculty or students.

The definitions of effectiveness when used may deny the opportunity to demonstrate the true effectiveness of higher education because they are so strongly grounded in management science. practitioners must be aware that they are using definitions, models, and measures of management performance rather than definitions, models, and measures of effectiveness . . (pp. 38-39) 
A review of the literature since this 1991 analysis revealed that no further research has addressed the opinions of instructional stakeholders toward student outcomes assessment goals.

For the community college, identifying and describing the values held by faculty and administrators and determining how the values of various constituent groups within this larger group differ provides an important base of knowledge. This knowledge can serve as a foundation for selecting student outcomes for use as effectiveness indicators. It may explain the involvement or lack of involvement of instructional stakeholders in current outcomes assessment programs. It also may suggest whether changes in current outcomes assessment programs would increase stakeholder buy-in on the part of teachers and administrators and be more likely to result in improved teaching and learning.

\section{Rationale for the Study: Research Questions}

The purpose of this study is to address the problem of determining which student outcomes the instructional stakeholders of the large, urban, multi-campus perceive to be the most important for the students they serve. The researcher has given the college the fictitious name Sunshine Community college. The study determines whether different constituent groups within the larger grouping of 
instructional stakeholders vary in their goals for students and, if so, how they vary.

The questions addressed by this study are:

Research Question 1. Of the wide array of student outcomes that are perceived by instructional stakeholders to be relevant for students in community colleges, which do instructional stakeholders as a whole perceive to be most important?

Research Question 2. Can the 23 student outcome goals be factored into a smaller number of underlying constructs or dimensions?

Research Question 3. Does the perceived importance of student outcomes vary in relationship to the type of students the stakeholder serves most often--that is, professional/technical, lower division collegiate, or developmental?

Research Question 4. Is it possible to predict which outcomes are valued most highiy be stakeholders based on the type of students they serve?

Research Question 5a through 5e. These questions asked whether the perceived importance of student outcome goals vary in relationship to other stakeholder biographical characteristics; specifically: (a) the type of students the stakeholder serves most often, (b) the stakeholder's professional role, (c) the number of years the stakeholder has worked in a community college, (d) the number of years 
the stakeholder has worked at Sunrise Community College, (e) the campus assignment of the stakeholder, and ( $f$ ) the stakeholder's gender.

\section{Significance of the study}

Sunrise Community college (SCC), like many community colleges across the nation, is currently grappling with the problem of designing a student outcomes assessment program that can be utilized effectively to improve its educational programs. One of the keys to accomplishing this goal is to insure that the values of instructional stakeholders, those individuals in the institution who are directly responsible for designing educational programs and selecting teaching strategies, find value or merit in the outcomes selected for assessment. This study generates information about these instructional stakeholder values.

This study is significant in three ways. First, the data generated by this study can be directly utilized by Sunrise Community college to achieve the goal of identifying student outcomes that are of value to the instructional stakeholders in the institution. If the outcomes identified through this process are assessed by the college, the results are more likely to be used by the stakeholders to modify programs, curriculum, and teaching strategies. The research will also aid the college in determining whether a single set of outcomes which represents the values of all 
stakeholder groups can be employed universally by the college.

In addition to informing the design and utilization of the outcomes assessment program, the results may imply the need for other organizational work. For example, should a discrepancy be found between the college's stated mission and objectives for student learning and the values of the staff, the college may choose to address those differences through specific staff development efforts or a revision of the mission and objectives. Policy makers may find that the data can inform policy development.

Second, the research design can be utilized by other community colleges that are either embarking on a student outcomes assessment program or finding themselves in need of more information about their instructional stakeholders in order to continue the process of developing one. As the review of the literature reveals, the need for community colleges to define and adopt student outcome goals for assessment purposes is a national phenomenon and one that is likely to continue.

Finally, the results of this study, conducted at a single institution, may surface issues and questions which have relevance of a broader scope than the current study encompasses. Researchers may pursue these questions with a larger population representing a cross-section of postsecondary institutions. 
Definition of Terms

For the purposes of this study, key terms are defined below.

Development. Development is a change in affect, cognition, or behavior which persists over time and which is not ascribable to the processes of growth.

Developmental Education. Developmental education is an organizational division of a community college that includes departments offering courses that prepare students for higher level course work but which do not directly prepare students for a professional/technical occupation or are not transferrable to four year colleges or universities.

Goal. A goal is an end toward which effort is directed.

Instructional stakeholders. Instructional stakeholders are the teaching faculty, support staff and administrators who have decision-making responsibilities in areas directly related to instruction. At Sunrise Community college, administrators who meet this criteria are deans, the vice President for Educational Services, and the President. Support staff include advisors, counselors and librarians. Learning. Learning is "a change in human disposition or capability, which persists over time, and which is not simply ascribable to processes of growth" (Gagne, 1977, p. 3). 
Lower Division College. Lower division college is an organizational division of a community college that includes all departments offering for credit lower division courses which can be used for transfer to four-year colleges and universities and which can be used to satisfy the associate of arts, associate of science, or associate of general studies degree requirements.

Lower Division Transfer Student. Lower division transfer student is a student enrolled in a course or courses offered by the lower division college that can be transferred to baccalaureate granting institutions and used to fulfil baccalaureate degree requirements.

outcome Goal. Outcome goal is a change in students' knowledge, skills, attitudes and behavior resulting from their educational experiences which is a desired end toward which effort is directed.

Outcomes Assessment. Outcomes assessment is at systematic effort to gather accurate information about students' knowledge, skills, attitudes and behaviors to be used for the purposes of evaluating institutional effectiveness.

Professional Role. Professional role is the formal function an individual performs in the institution, such as instructor, counselor, administrator, and advisor.

Professional/Technical Education. Professional/ technical education is an organizational division of a 
community college that includes programs which provide education aimed at training students for specific technical and professional occupations. All departments within this designation offer courses for credit and certificates and/or associate of applied science degrees.

Stakeholders. Stakeholders are:

various persons and publics who may be affected by a program or who hold a stake in determining the direction of an educational endeavor, identifying concerns and issues to be addressed in evaluating a program, and selecting the criteria and variables that will be used in judging its value. (Worthen \& Sanders, 1987, p. 412)

In a postsecondary educational institution stakeholders include students, instructors, administrators, parents, employers, taxpayers, legislators and other community members.

Support Staff. Support staff are librarians, academic advisors and counselors.

value. Value, as a noun, is defined as a judgment attributing an estimate of worth to a cercain entity. More specifically, a value is a belief that a specific behavior or way of conduct is personally or socially preferable to the opposite behavior. As a verb, to value means to confer that estimate of worth. 
CHAPTER II

REVIEW OF THE LITERATURE

Introduction

The impetus and primary purpose of each of the outcomes assessment initiatives described in chapter $I$ is to generate change in local institutions that will result in improved education for students. While accountability is certainly a subtext of the rationale for assessment, regulatory roles are almost always presented as means to a single end: If colleges are held accountable for specific student outcomes, they will take meaningful steps in the classroom and other areas to improve those outcomes. Thus, this review of the literature treats outcomes assessment as an educational change effort. The aim of this literature review is to support the following premises: (a) outcomes assessment is a reform movement that will persist in postsecondary institutions; (b) outcomes assessment is a change effort and, consequently, is subject to the principles that govern change efforts; and (c) increasing our understanding of teachers' and instructional administrators' beliefs about student outcomes will contribute important knowledge to the education leadership field because these beliefs directly affect the ability and willingness of these critical 
stakeholders to integrate this change effort into their dayto-day activities in the institution.

In order to achieve its aim, the literature review examines four important areas of scholarship. To provide background information, the first section describes the historical development of the student outcomes assessment movement and provides additional evidence that outcomes assessment in the community college is likely to enjoy a robust future. The second section explores the literature related to the problem of identifying outcomes to assess. The third section describes a model for effecting change in educational institutions and focuses on the influence of teachers in educational change efforts, particularly the role teachers' belief systems play in resisting or facilitating change. In addition, this section addresses the organizational development literature as it supports the notion of stakeholder participation in setting organizational goals. The fourth section addresses theories in strategic planning and educational evaluation, two change interventions related to outcomes assessment that have been formally adopted by scc. Current theory in both areas emphasize the importance of stakeholder support of organizational goals as a condition which facilitates organizational change and improvement. 
Historical Background of the Student outcomes Assessment Movement

The history of student outcomes assessment in the United stated reveals a movement that has grown steadily over the past two decades. Scholars and practitioners in the field of higher education initiated the assessment movement by advocating outcomes assessment as a means of making institutions more accountable for and effective in their primary role--teaching students. States and federal governing bodies have increasingly mandated outcomes assessment as a condition of funding higher education. Accrediting agencies now require that all institutions develop an outcomes assessment program as a condition for accreditation. As these developments have occurred, existing and newly formed postsecondary professional organizations have attempted to assist institutions as they struggled to learn about and develop outcomes assessment programs.

Despite these developments, many institutions have not begun or are still in the process of designing outcomes assessment programs. The following sections trace the development of the assessment movement and support the proposition that student outcomes assessment will be a permanent fixture in higher education for many years to come and, as a result, warrants research that will inform 
practitioners' efforts to design effective outcomes programs.

The Emergence of the Assessment Movement

One of the earliest public calls for developing assessment methods that would measure students' learning in order to evaluate institutional effectiveness was the National Institute of Education's (1984) Involvement in Learning: Realizing the Potential of American Higher Education. This report recommended viewing assessment as a way to demonstrate improvements in student knowledge so that institutions could improve their accountability. The report identified higher academic standards, student involvement, and assessment as the three primary conditions necessary to develop educational excellence in higher education.

other national reports followed, each recommending assessment of student learning as a means of achieving excellence. Two which received widespread attention were To Reclaim a Legacy (Bennett, 1984) and Integrity in the College Curriculum (Association of American Colleges, 1985). In their report Time for Results (National Governors' Association, 1986) the Governors' Subcommittee on Education made the following three recommendations related to outcomes assessment: (a) Each college or university should implement assessment programs and use multiple measures to evaluate student learning; (b) Information resulting from assessment 
should be made available to the public; and, (c) Funding formulas for public institutions should include incentives for improving learning which are based on assessment findings.

Finally, the Program and Institutional Assessment Task Force of the State Higher Education Executive Officers (SHEEO) made the following recommendations regarding outcomes assessment: (a) Degree granting institutions should assess students at entry to evaluate their readiness to take courses toward a degree or to determine the need for remediation; (b) states should establish uniform ways of defining and calculating completion and retention, and should measure them at each institution; (c) Institutions should set: general education goals for undergraduates and measure the achievement of those goals; (d) Although the definition of what constitutes general education may differ from institution to institution, all institutions should include basic skills in reading and writing and critical thinking in their definition; (e) Alumni's satisfaction with their education should be assessed; and, (f) Accreditation agencies should use the results of assessment in the accreditation process (Roaden et al., 1987).

\section{State Mandlates for Assessment}

In the wake of this spate of national reports, state legislatures and boards of public postsecondary systems responded to the demands for evidence of student learning 
and development with a surge of activity. A 1987 survey of 50 states found at least two thirds had adopted initiatives which could be characterized as assessment mandates compared with only four in 1985 (Boyer et al., 1987). These mandates emanated from either state legislatures or from state boards of education. Regardless of origination, by far the majority of states with initiatives eschewed statewide testing in their mandates and deferred decisions about the form assessment should take to individual institutions. Typically, initiatives called for colleges to: (a) determine and state their own educational goals for students, (b) document progress towards achieving those goals, and (c) report continuing efforts to attain unachieved goals. The research found that 25 states related that their efforts were directed primarily at fostering assessment and providing minimal assessment guidelines for institutions. The remaining 10 states imposed more rigorous assessment requirements, all featuring mandated testing to be conducted statewide. Of the former group, some states were more directive, requiring that assessment be included as part of statewide reviews or that institutional assessment plans be formally submitted, while others were less directive, focusing on encouraging assessment activity by offering technical assistance or incentive grants for piloting assessment programs. Some states included intervention requirements aimed at identifying underprepared 
students prior to enrollment and providing remediation either directly before or shortly after students arrive on campus.

Tennessee led the way in terms of assessment mandates when in 1984 the Tennessee Higher Education Commission implemented the Tennessee Performance Funding Program (Jaschik, 1985). The program tied assessment to the state's funding formula for public institutions. It initially provided for the incentive of a supplement of up to $4 \%$ of the instructional budget for institutions which were able to demonstrate the quality of their academic programs in their annual report to the commission. The supplemental funding has been increased to 5\%. An important feature of the Tennessee mandate is that colleges and universities are given the freedom to craft their own system for demonstrating effectiveness.

Unlike Tennessee, legislative mandates in a minority of states have been rigidly prescriptive. Two states, Texas and Florida, illustrate this prescriptive approach to assessment (Ewell, 1992). In both states, community colleges have been directly affected by the assessment mandates. Texas legislated the Texas Academic Skills Program in 1988, mandating that all students must take and pass a basic skills test before matriculating into the state's public higher education degree programs. Students not passing the test are permitted to enroll only in 
developmental education or non-credit courses. istudents are tested in reading, writing, and computation skills. Students who do not pass the test are allowed to enter community colleges as developmental education students but are barred from degree programs. In Florida, students must pass a basic skills test before they can earn an associate's degree from a community college, transfer to a public fouryear institution from a community college, or continue from the sophomore to the junior year if they are in a four-year institution. In both states, students who do not pass the test have the opportunity to remediate their skills and retake the test.

Legislation in California typifies the less prescriptive, more permissive mandates that are found in most states. The California state Assembly has passed Assembly Bill 1725, which prescribes minimum requirements for a:

comprehensive comunity college accountability system which describes the performance of community colleges in meeting the postsecondary educational needs of students[including] performance data on students, programs, and institutions. (California community Colleges $\mathrm{AB}$ 1725 Accountability Task Force, 1990, p. 3)

Each community college is authorized to develop an accountability system and performance criteria appropriate to its unique circumstances.

There are no signs that states are questioning the utility or feasibility of student outcomes assessment as an 
important means of judging institutional effectiveness. A force that will probably continue to propel state legislatures towards outcomes assessment mandates is the present nationwide decline in funding for higher education. During a period of shrinking budgets, it is likely that states will continue to be attracted to the notion that higher education should be held accountable for its performance in educating students and that outcomes assessment will continue to be viewed as a logical means to that end.

\section{Accrediting Association}

\section{standards}

As state legislatures and boards have developed assessment initiatives, postsecondary accrediting associations have followed suit. The Southern Association of Colleges and Schools (SACS) was the first accrediting association to require evidence of student learning and development as a condition of accreditation. In 1985, SACS Commission on colleges produced a major revision of its accreditation standards, which included the statement that institutions "must define [their] expected educational results and describe how the achievement of these results will be ascertained" (p. 9). Many affected colleges reacted with alarm, assuming that specific kinds of data from nationally normed tests would be required of them. To allay these fears and to help colleges develop assessment plans 
congruent with their own missions and educational goals for students, SACS produced an implementation manual. The manual listed a wide array of kinds of information as appropriate measures of student performance, including:

- student retention and completion rates,

- student achievement in general education,

- student achievement in the major field,

- student perceptions of their development toward educational objectives,

- student affective development,

- job placement rates, and

- performance after transfer from two-year to four-year institutions. (p. 12)

In 1987, the U.S. Department of Education adopted new guidelines for the approval of accrediting agencies that required that outcomes assessment be included in each agency's accreditation criteria (Banta, 1988; U.S. Department of Education, 1987). More specifically, the guidelines require that every accrediting agency will evaluate whether colleges and programs: (a) articulate and maintain educational objectives that support the institution's mission, (b) systematicaliy measure whether students are meeting objectives and document these measures, (c) disseminate for potential students the educational objectives and the results of assessment, and (d) utilize assessment results to improve the program and/or institution. Currently, all accrediting associations require evidence of student outcomes in some form. In 1992, the Northwest Association of Schools and Colleges' Commission on colleges revised its standard 
addressing educational programs and their effectiveness (standard V). Two criteria related to outcomes assessment were added to the existing standard. The first criterion explicitly calls for evidence of effectiveness derived from an assessment of outcomes:

The education of students is the primary reason for the existence of academic institutions... the commission emphasizes the necessity of a continuing process of academic planning, the carrying out of those plans, the assessment of the outcomes, and the influencing of the planning process by the assessment activities. Assessment which does not result in conscious and deliberative attempts at improvement is rarely worth the effort. (p. 47)

The second new criterion emphasizes that:

each internal academic unit, program, major or concentration :. . [will] conduct a separate study concerned with its role and development in terms of the mission of the entire institution, including general education/related instruction. (p. 48).

This addition to the standard is important for two reasons. First, it directs institutions to examine educational effectiveness at the department or program level. Second, it emphasizes that this examination at the department or program level is to include each unit's contribution to student learning in general education. Implicit in these two criteria is the lassumption that accreditation should include evidence of outcomes assessment at the program level and should include an assessment of general education outcomes as well as outcomes in the major.

Concurrent with revising standard $V$, The Northwest Association developed a "Policy statement on Educational 
Assessment." This discourse states, "The intent of Commission policy is to stress outcome assessment as an essential part of the ongoing institutional self-study and accreditation processes" (Northwest Association of Schools and Colleges, 1992, p. 54). It also provides illustrations of outcomes assessment queries that institutions can make in six different areas. The first area is "student information" related to input information--such as demographic and aptitude information about students--and outcomes information--such as retention, graduation, and grade distribution. Second is "mid-program assessments" of specific courses and sequences or of specific parts of the system for teaching general education. Third is "end of program assessment" including the graduation rate, the time taken to graduate, student gains in knowledge and skills. Fourth is "alumni satisfaction and loyalty" to determine the quality of the educational program as perceived by graduates. Fifth is "dropout/non-completers" information including the reasons for students' noncompletion of programs. And the sixth is "employment and/or employer satisfaction measures." One important theme runs throughout the description of each of these seven assessment areas; information that is collected should be evaluated, and judgments that are rendered from such evaluation should be used to improve programs (pp. 55-57). 
Assessment Programs at

Two-Year Institutions

As indicated in the Introduction, $61 \%$ of two-year colleges reported in 1989 that they assessed students in some manner and used the results to measure institutional effectiveness (Cowart, 1990). At the time, respondents expected the use of student outcomes assessment to increase over the next three to five years.

The American Council on Education (ACE), which has monitored student outcomes assessment activities in colleges and universities since 1986 in their annual publication Campus Trends, confirmed these expectations (El-Khawas, $1987,1988,1989,1990,1991)$. By 1990, 82z of two-year colleges reported some type of assessment activity.

Because the questions about outcomes assessment in the Campus Trends surveys tended to be general, ACE felt the need for more detailed information about the characteristics of these activities (El-Khawas, 1987, 1988, 1989, 1990, 1991). As a result, the organization conducted an in-depth survey in 1989 and 1990 of 2,619 representative two- and four-year colleges and universities. The results of this survey, reported in Assessing Assessment provide a clearer portrayal of the breadth and depth of assessment activities (Johnson et al., 1991). Researchers found that 30 of all postsecondary institutions were administering comprehensive student assessment programs while another $60 \%$ reported that they planned to implement programs in the future. of the 
1,311 community colleges represented by the sample, $33 q$ reported current comprehensive assessment programs and $67 \%$ indicated they planned to establish assessment programs. It is important to note here the distinction between how the term assessment program was used in the Campus Trends surveys and how it was used in Assessing Assessment survey. In the former, assessment was defined as any assessment activity whether at a single department level or at the comprehensive institutional level. In the latter, institutions were queried about "comprehensive" assessment defined as "efforts to measure undergraduate students' progress toward one to five categories of higher education objectives, usually in the arts and sciences" (Johnson et al., 1991, p. 2). This difference in definition prevented institutions which may have been only experimenting with one or two limited assessment activities from counting themsielves among those who operated comprehensive assessment programs.

The Assessing Assessment study found wide variation in the types of assessment that were being done at two-year colleges which claimed to be operating comprehensive assessment programs (Johnson et al., 1991). Moreover they found that fewer community colleges than four-year institutions were conducting comprehensive outcomes assessment programs. Table 1 displays the types of outcome assessment covered in the survey questionnaire and the 
percentage of colleges overall and the percentage of community colleges claiming to perform each type:

Table 1

Types of student outcomes Assessments Performed at Postsecondary Institutions

\begin{tabular}{llc}
\hline Type of Assessment & All & Two-Year \\
\hline Basic college readiness skills & $94 \%$ & $91 \%$ \\
General education/liberal studies & $67 \%$ & $61 \%$ \\
Major field of study & $63 \%$ & $57 \%$ \\
Career preparation/alumni follow up & $76 q$ & $72 \%$ \\
Personal growth and development & $65 \%$ & $61 \%$ \\
Other & $17 \%$ & $16 \%$ \\
\hline
\end{tabular}

Source: Johnson et al. (1991) Assessing Assessment. Washington, DC: American Council on Education, p. 13.

Note. Basic college readiness skills were defined as reading, writing, and mathematics.

The Problem of Identifying Appropriate outcomes to Assess

Much of the scholarship treating the technical issues related to outcomes assessment focuses on two issues--the types of variables that can be assessed to determine educational effectiveness and the means by which these variables can be measured. This section provides an overview of the relevant scholarship in the first area, literature related to identifying outcomes to assess. 
A number of taxonomies organizing and defining the outcomes of higher education have been proposed, ranging from Bloom's "Taxonomy of Cognitive Objectives" to Bowen's "Categories of Social Benefits of Higher Education" (Lenning, Lee, Micek, \& Service, 1977). A classification system developed for the National Center for Higher Education Management systems (NCHEMS) by Lenning et al. (1977) is perhaps the most detailed and thorough in terms of specifying categories of outcomes. This system identifies student acquisition of knowledge, social development, and personal development as the major classes of outcomes variables. It also integrates the concepts of audience (e.g., individual or group clients, interest based communities, geographical-based communities) and time (i.e., when the outcome is expected to occur) into the structure. The categories included in NCHEMS' classification system are shown in Table 2 .

Departing somewhat from Lenning et al. (1977), most researchers have classified outcomes variables into the following three categories--cognitive growth, skill development, and attitudinal development (Astin, 1974; Ewell, 1985; Pace, 1979, 1985). Within these categories, a range of skills, knowledge, behaviors, and attitudes have been suggested as appropriate variables for assessment. Astin's (1974) taxonomy is most frequently cited in 
Table 2

NCHEMS' Type-of-Outcome Dimensions

Outcome Entity Being Changed/Maintained

Human Characteristics Outcomes

\section{Aspirations}

Desires, aims and goals

Dislike, likes and interests

Motivation or drive level

Aspirational outcomes

Competence and skills

Academic skills

Citizenship skills

Family membership skills

Creativity skills

Expression/communication skills

Intellectual skills

Interpersonal skills

Occupational skills

Physical and motor skills

Morale, affective characteristics

Attitudes and values

Beliefs, commitments

Feelings and emotions

Mores, customs and conduct

Other affective outcomes

Personality/personal coping

Adventurousness/initiative

Autonomy/independence

Dependability and responsibility

Dogmatic/open-mindedness

Flexibility and adaptability

Habits

Psychological functioning

Tolerance/persistence

Other personality/coping outcomes

Physical and physiological characteristics

Physical fitness and traits

Physiological health

Other physical or physiological outcomes

Status, recognition/certification

Completion/achievement/award

Credit recognition

Image, reputation or status
Human Characteristics Outcomes (cont)

Licensing and certification

Obtaining job/admission to adv prgrm

Power and/or authority

Job, school, recognition outcome

Perceptual characteristics

Perceptual awareness

Perception of self ।

Perception of others

Perception of things

Other perceptual outcomes

Social activities and roles continued

Family activities and roles

Friendships and relationships

Citizenship activities

Social activities

Adjustment to retirement

Affiliations

Avocational/social activities

Knowledge, Technology and Art Form Outcomes

General knowledge and understanding

Knowledge/understanding of general facts

Knowledge/understanding of general

processes

Knowledge/understanding of general theory

Specialized knowledge and understanding

Research and scholarship

Research/scholarship knowledge

Rescarch/scholarship product

Art forms and work

Architecture

Dance

Debate/oratory

Drama

Literature/writing

Music

Sculpture

Other fine arts 
assessment studies because of its simplicity and comprehensiveness.

Astin's (1991, p. 45) taxonomy classified outcomes on the basis of three dimensions: (a) type of outcome, which is broken into two groups--cognitive or affective, (b) manner of gathering data, which is also dichotomous--either behavioral and obtained through direct observation or psychological and obtained inferentially through testing, and (c) time of capturing data, which again is dichotomous-either short-term and measured during the college experience or long-term and measured after leaving college. Table 3 reproduces this typology.

\section{Selecting outcomes to Assess}

As institutions have embarked on outcomes assessment, practitioners have grappled with the problem of identifying which student outcomes to choose as targets of assessment. This undertaking has emerged as a central issue and is one of the key decisions to be made by any institution developing a student outcomes assessment program (Ewell \& Lisensky 1988; Hanson, 1988). Implicit in the question "Which outcomes will we, as a college, choose to assess?" is the assumption that the selection of outcomes are important, are valued by the institution. It implies that these are the primary goals the institution holds for its students (Astin, 1991). Consequently, the process for choosing 
formal outcome goals for students should be undertaken with care.

Table 3

Astin's Taxonomy of student outcomes

\begin{tabular}{lll} 
Type & Type of outcome & \\
of Data & Cognitive & Affective \\
\hline
\end{tabular}

Psychological

Subject-matter knowledge Academic ability Critical thinking ability Basic learning skills Special aptitudes Academic achievement

Values
Interests
Self-concept
Attitude
Beliefs
Satisfaction
with college

Behavioral

Degree attainment Vocational achievement Awards/special recognition

\author{
Leadership \\ citizenship \\ Interpersonal \\ relations \\ Hobbies/avocations
}

Source: Astin, A. W. (1991). Assessment for Excellence: The Philosophy of Assessment and Evaluation in Higher Education. New York: MacMillan.

The assessment literature recognizes three primary factors that can inform the process of identifying outcomes to assess. First, the institution can be influenced by external forces such as external experts (for example, Peter Ewell and Alexander Astin) or government policy. External pressure primarily takes the form of state and federal mandates and accreditation standards requiring that specific 
outcomes be assessed. As discussed above, governmental entities are increasingly issuing such mandates (El-Khawas, 1989, 1990, 1991). Business and industry can also influence the choice of outcomes, particularly in professional/technical programs (Hoachlander \& Rahn, 1992). Second, the institution's formal mission statement and related educational objectives are important sources of influence. Third, institutions can look to internal institutional stakeholders, that is, their faculty, administrators, and students to select outcome goals (Altieri, 1990; Erwin, 1991; Heany, 1990; Nichols, 1991).

When one looks at these three primary factors which can influence an institution's selection of outcomes criteria, one can see that each has strengths and limitations. External federal and state mandates prescribing specific outcome measures tend to incorporate outcomes that are applicable to a broad range of institutions. This characteristic allows institutions to measure themselves against others and, in theory, provides a yardstick of effectiveness. However, the outcome measures also can fail to take into account the uniqueness of individual institutions and may fail to capture institution-specific types of student success.

Kreider and Walleri (1988) recognized the problems inherent in externally mandated requirements to assess outcomes. They claimed that increasingly "detailed and 
uniform state-level assessment mandates" (p. 33) are a threat to the community college in that they do not necessarily take into account "the diversity of the community college student population and mission" (p. 33). They arcyed that such external mandates raise serious policy questions for community colleges. Foremost among these are questions related to access, the appropriateness of standardized tests for heterogeneous populations, and the impact of accountability/assessment initiatives on the quality of instruction.

A college's formal institutional mission and related goals also can give direction to identifying appropriate outcomes criteria. These formal statements of purpose are most useful if the institution has a homogeneous student body, a relatively narrowly focused mission, and a welldeveloped and effective planning process. In such institutions, the formal mission and goals usually can be stated clearly and are likely to be agreed upon by most stakeholders because the faculty and student body tend to be homogeneous. Such institutions may be able to extract from their formal mission and goals statements student outcome goals that reflect their institutional uniqueness, and the planning process can be used to build and maintain consensus related to these goals. However, for institutions that serve many subgroups of students with diverse educational 
needs and goals, it is more difficult to produce a set of outcomes that reflect this variation.

one additional problem can occur when institutions rely on their formal statement of mission and goals as a source for identifying student outcomes. The institution's public presentation of mission and goals and internal stakeholders' privately held conceptions of educational goals may not be the same. A mission and goals statement is a public value statement.| Scriven (1967) distinguishes between rhetorical values, that is, the formal value system to which a group publicly subscribes and true values, that is, the values to be deduced/from the behavior of the group. The mission and goals statement may have been written to serve political, public relations or other purposes and, as a result, may not reflect the "true" values of internal stakeholders or the genuine educational needs and goals of students. Practitioners must determine the purpose of the institution's formal mission and goals statement before they can evaluate their usefulness for the purpose of identifying outcomes to assess. Most organizational development experts agree that if publicly stated goals are not held by internal stakeholders, the organization will have difficulty moving in the direction of achieving those goals (Argyris, 1970; French, Bell \& Zawacki, 1989; Shine, 1965).

Even without the problems inherent in a scenario in which an institution's formal mission statement does not 
represent the true values of its internal stakeholders, the comprehensive community college presents challenges to the notion of using formal mission and goals statements as a source of student outcome goals. Most community colleges have at least five distinct instructional programs, including professional/technical education, lower division transfer education, developmental education, adult basic education, and community/continuing education (Alfred, 1986). With this diverse mission and mixed student population, the community college has great difficulty pulling from its mission a single, coherent set of valued goals for students to which the college as a whole can subscribe.

Indeed, the diversity of roles described above has resulted in competing theories of what the primary mission of the community colleges ought to be. This disagreement has become a consistent theme in the community college literature. One common point of view is that the mission ought to focus on preparing students for transfer because transfer provides access to professional occupations which are viewed as the most effective mechanisms for raising people's socio-economic status (Bowles \& Gintis, 1976; Brint \& Karabel, 1989; Clajek, 1960, 1980; Jencks \& Reisman, 1968; Karabel, 1972, 1974;'Nasaw, 1986; Pincus, 1980; Zwerling، 1976). A subtheme of this critical literature argues that the community college has inappropriately concentrated on a 
developmental education mission and, furthermore, that this focus has affected the transfer curriculum negatively. To these critics, developmental education programs, which focus on personal development and specific basic skill development, much of it at a relatively low level, have spread their low standards of achievement "both vertically and horizontally even into university parallel programs" (McGrath \& Spear, 1991, p. 52). These critics maintain that the growth of developmental education in community colleges has had the effect of what they call "dumbing down" the curriculum at the expense of rigorous intellectual training that has the power to transform a student's understanding of and place in the world.

The underlying question raised by each of these criticisms is this: What is the legitimate mission of the community college? To most of the critics cited above, the appropriate mission is to educate students in such a way that they have access to four-year colleges and universities and, consequently, to positions of power in our society. However, competing notions of the community college mission maintain a vigorous existence. Many community college leaders, public policy-makers, and teachers believe that the mission must include producing well-prepared workers for skilled and semi-professional occupations and providing a social service mission of affective development that includes developing minimal concrete (basic) skills. 
The disagreement and controversy regarding the community college mission found in the literature suggests that appreciable differences will be found among instructional stakeholders regarding the student outcome goals they value and seek to foster.

Organizational Behavior: Implementing Change in Educational Institutions

Many attempts at program change have concentrated on product development, legislation, and other onpaper changes in a way that ignored the fact that what people did and did not do was the crucial variable. (Fullan, 1991, p. 65)

clearly, educational change that has as its intent changing student outcomes requires some change in the behavior of teachers in the classroom. If, for instance, the aim is for students to acquire a specific set of workplace competencies, explicit values related to cultural diversity, or a body of knowledge about the natural environment, teachers must employ planned curriculum and instructional technology to achieve these outcomes. Even if an outcome goal for students is broader than such explicit learning outcomes--for example, students are to earn a formal award or get a job related to their field of study-teachers in their role as advisors, mentors and mediators impact the outcome by their purposeful interactions with students in and out of the classroom. If plans for educational change are to result in genuine change, teachers must change their behavior. 
If the above assertion is accepted as true, the issue of how purposeful change is implemented in an educational institution is critical. The following section describes a paradigm which explains how planned change is achieved in educational organizations and provides a framework for describing how the beliefs teachers hold affect a planned change effort such as implementing student outcomes assessment.

Fullan (1991), in The New Meaning of Educational Change, has posited a paradigm for change that explains and clarifies the important role that teachers' beliefs toward any proposed change play in its successful implementation. In the Fullan paradign, change occurs in four phases: initiation during which innovation is introduced, implementation during which it is put into practice, continuation during which change is institutionalized, and outcome during which the desired improvement is more of less consistently present. An institution typically takes 3 to 10 years to work through all four stages of planned change. As Figure 1 shows, at the initiation stage at least five influences can stimulate a change effort: administration or teacher advocacy, new governmental policies, community pressure, or other external change agents. In each stage, key factors or variables--which the author organizes under the categories "characteristics of the planned change, 
external factors, and local institutional characteristics"-influence the success of the change effort.

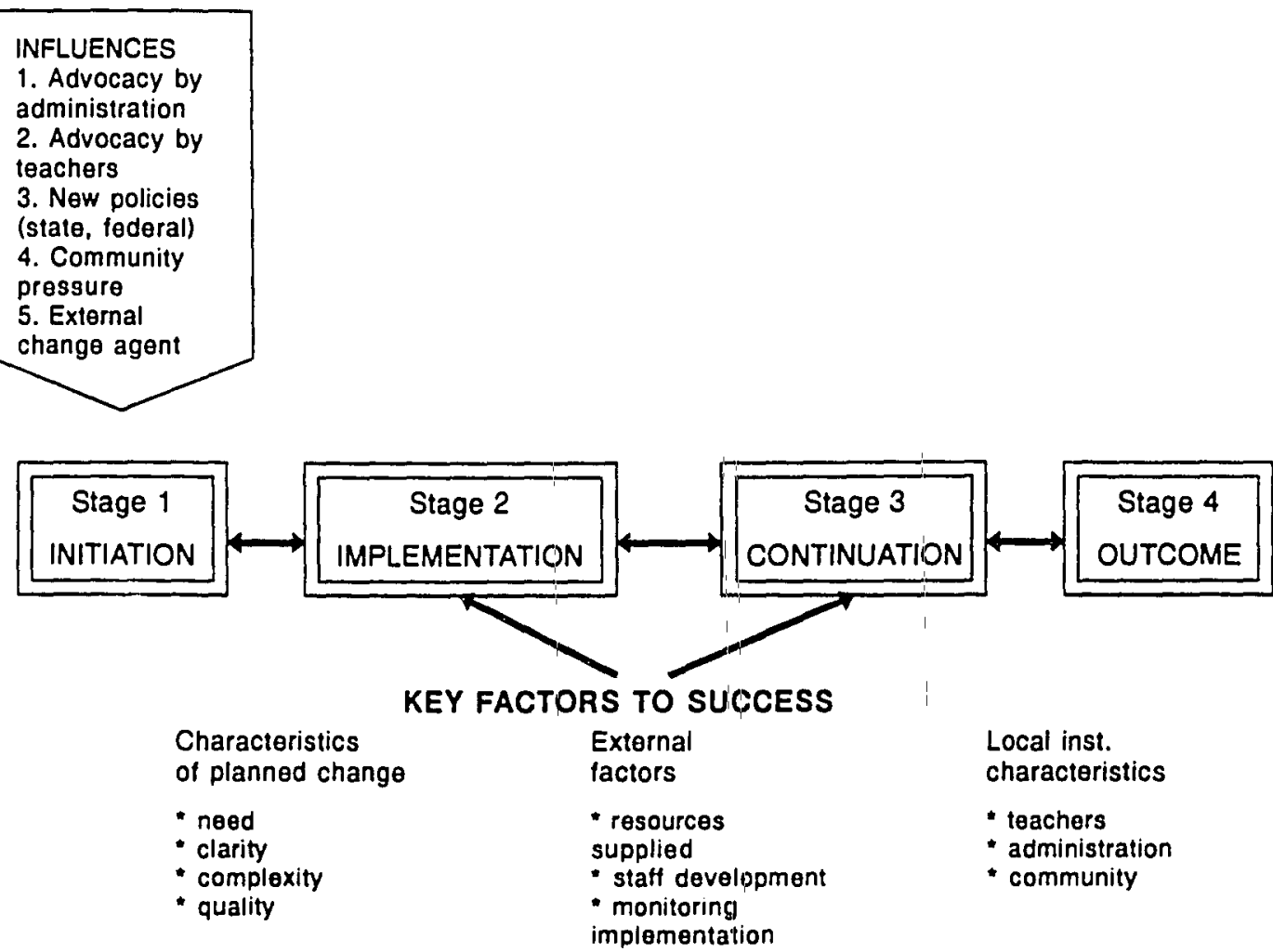

Fiqure 1. Factors explaining the effectiveness of planned change efforts.

While each of the factors affect the degree to which change is successfully realized, equal weight is not given to each factor in terms of the degree of influence each has to facilitate or impede the change leffort. In this change paradigm, teacher characteristics, especially teachers' ability to ascribe positive meaning to the change effort in question, carries more weight than do the other factors. 
Fullan (1991) has examined the research related to the behavior of teachers involved in planned change efforts and concludes that the most important variable governing whether teachers adopt and utilize a change initiative is their ability to ascribe a meaning to the change that they can integrate into their existing belief structure. Change, he found, affects individuals by threatening them with "loss and struggle" (p. 31). Change is perceived as a threat, in part, because the meaning of change initially is rarely clear. An individual who cannot ascribe meaning to change cannot and will not assimilate or integrate change into his or her subjective reality. Almost all individuals have a "conservative impulse" (p. 30) toward change which manifests itself as rejection. Moreover, the nature of teaching strengthens this tendency to reject change. Because teachers are busy coping with the immediacy of the classroom--particularly the need to develop and maintain personal relationships with many students--they are subject to what Huberman (1983) termed "classroom press." As a result, they have little time to reflect on their practice, consciously consider the need for change, or think through the pros and cons of various change possibilities. These conditions further dampen teachers receptivity to change. The resistance of teachers to change is clarified by Marris (1975) :

Occupational identity represents the accumulated wisdom of how to handle the job, derived from 
their [teachers'] own experience and the experience of all who have had the job before or share it with them. Change threatens to invalidate this experience, robbing them of the skills they have learned and confusing their purposes, upsetting the subtle rationalizations and compensations by which they reconciled the different aspects of their situation. (p. 16)

In a social system such as a school or college, the system itself contributes substantially to the meaning individuals make of reality.

Social systems provide . . . a framework of theory, values, and related technology which enables individuals to make sense of their lives. Threats to the social system threaten this framework. (Marris, 1975, p. 51)

Thus, social systems, like individuals, have a strong tendency to resist and reject change unless it is integrated into and meaningful within the context of that system. In other words, to be accepted by the social system, the meaning of change must be integrated into the existing set of symbols, myths, norms and values.

Fullan's (1991) paradigm, therefore, is predicated on the assumption that "real change whether desired or not represents a serious personal and collective experience characterized by ambivalence and uncertainty" (p. 32).

other researchers of postsecondary institutions have found that a cultural center exists in individual colleges and that this center is made up of beliefs and values that are venerated by the members (Sergiovanni, Burlingame, Coombs, \& Thurston, 1992). In a sense, these are perceived as almost sacred. Cultural centers are sources of identity 
for teachers from which their occupational lives become meaningful. These researchers, too, found that the institution's culture played a critical role in the attainment of objectives:

The 'stuff' of culture includes a school's customs, traditions, historical accounts and unstated assumptions, habits, norms and expectations, and common meanings and shared assumptions. The more understood, accepted and cohesive the culture of the school, the better able it is to move in concert toward . . . objectives. (p. 158)

One of the most prevalent ways change efforts are implemented is for administrators or governance bodies simply to introduce a new set of goals. This "rational solution . . has backfired because it ignores the culture" (Fullan, 1991, p. 35) of the institution. Simply inaugurating new goals and mandating teachers to operationalize them "resulted in confusion, frustration, anxiety, and abandonment of the effort" (p. 35).

Fullan's (1991) change paradigm with its emphasis on teachers: strong inclination to reject change initiatives that they cannot integrate into their personal and social meaning structure is compatible with scholarship related to the governance of postsecondary institutions. In general, all colleges are characterized to varying degrees by ambiguous goals, ambiguous technology, a professionalized class of workers and external vulnerability. While the formally espoused goals of an institution can be changed by administrators applying a rational, bureaucratic approach to 
governance, decisions about whether to undertake achieving these goals are made by teachers who are not operating in concert with a rational, bureaucratic model. Three models of academic governance enjoy varying levels of support in the literature: governance by organized chaos (Cohen \& March, 1986), governance through a political process of negotiation (Baldridge \& Deal, 1983), and governance by collegial consensus building (Clark, 1975). In each of these non-rational, non-bureaucratic models, stakeholders are described as having the power to subvert decisions and goals handed down to them by administrators or external sources.

Implementing an outcomes assessment program constitutes a consequential change in an institution simply by virtue of the fact that it demands that new technology be employed to determine student success. Fullan's (1991) change paradigm suggests that if goals are adopted, in the form of student outcomes, that are different from those that individuals in the system believe are important (that is, can integrate into their personal and social meaning structure) then a profound change is planned. Clearly, such a change would be likely to challenge, in Fullan's words, the occupational identity of teachers. It also would challenge the cultural center of the social system as a whole.

In the opinion of this author, currently when an outcomes assessment program is introduced at a community college, the initiation phase is most heavily influenced by 
state and federal policy and administrator advocacy, not teacher advocacy. Based on this observation, the author believes that an assessment program developed at sunrise Community college would be similarly influenced. Consequently, it is quite possible that the outcomes adopted in an outcomes assessment program would differ from those teachers believe are important. Assuming that sunrise Community college corresponds to one or a combination of the non-rational governance models, it is clear that failure to consider the preferences and values of stakeholders regarding the student outcomes selected for assessment is very likely to jeopardize the successful initiation of the college's student outcomes project. This supposition points to the importance of investigating--as this study will--the beliefs teachers currently hold related to the student outcomes they are working to effect.

\section{Organizational Development}

\section{Theory}

Organizational development (OD) theory, supports the change paradigm outlined above and the importance of investigating college teachers' beliefs about the student outcomes they recognize as meaningful. OD research has established that organizational goals are more likely to be achieved if stakeholders within the organization have a sense of ownership of those goals. Furthermore, ownership 
is most likely to occur if internal stakeholders have a meaningful role in determining the organization's goals. student outcomes assessment $\mid$ is predicated upon the belief that improvement in educating students results from closely examining how successfully students are achieving the goals the institution has established for them. An assumption underlying this belief is that organizations will change and improve in reaction to information about how well they are achieving their goals. Indeed, organizational development theorists hold that an important characteristic of effective organizations is that they manage their activities in a planned manner to achieve goals (Beckhard, 1969 ; Schmuck \& Miles, 1976; Shine, 1965). Moreover, these goals must have certain characteristics, specifically, clarity, feasibility, appropriateness and acceptance by organizational members (Miles, 1966; Schmuck, 1988).

It is the last characteristic, acceptance by organizational members, that relates to the current problem. Shine (1965) asserted that within an organization willingness to change will not exist if widespread commitment to goals is not present. He found that consensus regarding goals led to more cooperative group relations and greater task accomplishment. Argyris (1970) called goal acceptance "internal commitment"।(p. 109), meaning that:

the course of action or choice has been internalized by each member 1 . . Each member is acting on choice because it fulfills his own needs 
and sense of responsibility as well as those of the system. (p. 112)

This concept of internal commitment is commonly referred to as ownership. Legge (1984, p. 61) found that the "personal factor" was the best predictor of utilization of information to effect change regardless of the importance or currency of the information. He defined the personal factor as the interest users have in the topic. A goal that is highly valued by an individual is more likely to enjoy the personal factor than one that is not.

In their review of the organizational development literature, Friedlander and Brown (1974) concluded that goal acceptance reflects a larger value that prevails in organization development theory--democracy and humanism. This democratic proclivity, they found, does not negate the need for strong leadership. Most $O D$ authors do not challenge the assumption that change efforts can and should be managed from the top down; however, they hold that the most effective change efforts are characterized by stakeholder commitment to the change goals (Braskamp \& Krug, 1989 ; Hackman, 1986; Lawler, 1986). McGregor (1960) in developing his revolutionary Theory $\mathrm{Y}$ also addressed the need for goal acceptance by the members of an organization. He stressed that management's primary function was to ensure that the organization helped people achieve their own goals while achieving the goals of the organization. 
It is clear from the organizational development literature that stakeholder acceptance of an organizations' espoused goals is an essential determinant of whether those goals will be achieved.

\section{Strategic Planning and Program Evaluation: stakeholder Participation in Two Change strategies}

Recent scholarship in two related disciplines-strategic planning and program evaluation--provides a rationale for conducting the research undertaken in this study. Both disciplines are concerned with improving institutions' ability to judge their effectiveness and to plan for change. Sunrise community college has formal programs for strategic planning and program evaluation.

A review of the literature in each discipline reveals an evolution of thought which recognizes that stakeholder support of organizational goals increases the likelihood that the organization will achieve those goals. The strategic planning literature has focused on developing effective processes for using information to improve organizational decision-making. Strategic planning models have incorporated the notions of stakeholder "buy in" found in the OD literature. Educational evaluation theorists, particularly Guba and Lincoln, have championed participantoriented evaluation which has as its purpose fulfilling stakeholders' needs for information while attending to the 
value systems of various stakeholder groups. The idea that organizational goals are reflections of value systems is fundamental to this conception of evaluation.

\section{Strategic Planning}

Strategic planning is a specialty area that has grown out of organizational behavior and management theory. Keller's (1982) Academic Strategy: The Management Revolution in American Higher Education described a new kind of organizational planning in postsecondary education. Based on case studies of diverse institutions across the country, Keller's work analyzed the problems besetting higher education and described a transformation in the management model that many of the most successful institutions were using to cope with these problems. He lobserved that incrementalism, the dominant form of planning in the $1960 \mathrm{~s}$ and 1970s, was giving way to a strategic planning model. Keller found that the key concept in this model was the need for institutions to assess their internal and external environments in order to identify opportunities and potential problems or threats inherent in those environments. With this information, institutions can craft missions and goals that are likely to increase their effectiveness and their ultimate survival as organizations. strategic planning models generally begin with an assessment of the institution and its environment. The second stage involves identifying alternative visions of the 
institution that could be adopted as its mission. The third stage calls for adopting one of those alternatives based on the institutions' strengths and weaknesses and its fit with the environment. The fifth stage involves developing and implementing a strategy and related policies aimed at realizing the selected vision. The process is cyclical because once implementation takes place the assessment phase must begin again which in turn triggers the subsequent stages. The external and internal environments continue to change in planned for and in unanticipated ways, and the institution which is committed to strategic planning continues to assess and respond to these environments (Cope, 1985; Kotler \& Murphy, 1981; Peterson, 1980; Shirley \& Volkwein, 1978; Trachtenberg, 1978).

Most strategic planning theoreticians subscribe to a model of institutional governance in which there is shared authority and influence between the administration and faculty (Haas, 1980; ricclenney \& Chaffee, 1985; Mortimer \& Mcconnell, 1978). It is not enough, they argue, simply to develop sound strategic planning processes and structures. The process must be made operational, and in an institution with shared governance, the plans and strategies will not be effectively implemented unless the faculty support the mission and goals underpinning these plans. When the strategic plan includes goals related directly to 
instruction, as they do in the student outcomes arena, it is imperative that instructional stakeholders support them.

\section{Educational Evaluation}

Developments in the field of educational evaluation during the last three decades, provide persuasive rationale for investigating whether the faculty and instructional administrators as stakeholders agree to the importance of student outcome goals posed as criteria for determining institutional effectiveness. A review of the literature shows that attention to the role that stakeholders ought to play in shaping evaluation agendas and in determining evaluative criteria for educational programs is fairly recent.

Guba first introduced the notion in 1969 when he castigated the evaluation profession, charging that "innovations have persisted in education not because of the supporting evidence of evaluation but despite it. . . Evaluation as we know it has failed" (p. 29). He claimed that the evaluations of the 1960 s Great Society educational and social programs had shown no significant effectiveness not because the programs were ineffective, but because the evaluation methods were inappropriate. In his view, the underlying problem was that the evaluator's primary role in objectives oriented evaluation was to develop

a set of objectives that were sufficiently operational so that the required congruence [between objectives and outcomes] could occur 
- . The objectives themselves, in general form, were obtained by an almost mystic process that

remained relatively unspecified. (p. 31)

This inattention to who chose the objectives and by what or whose philosophy they were chosen resulted in a process that "was devoid of value judgments and was, sociologically and culturally, antiseptic" (p. 36). He claimed that when "multiple values are applied . . the same data when interpreted in terms of different value standards will give rise to antithetical evaluations" (p. 36). In other words, the outcomes of an educational program may be successful by one group's standards, but unsuccessful by another's.

In the 1970 s evaluators increasingly recognized that reliance on descriptive, objectives oriented evaluation, using traditional research designs and quantitative measurement and instrumentation were failing to produce effective evaluations. Many came to believe that research and data gathering for the purposes of evaluation must be conducted by rules which were difierent from those that guided experimental research. Evaluators acknowledged that the results obtained from objectives-oriented research techniques, especially those relying on norm-referenced, standardized tests were not "serving the information needs of the clients of evaluation; addressing the central value issues; or dealing with situational realities . . ." (Madaus, Stufflebeam, \& Scriven, 1983, p. 16).

Evaluators began to recognize that: 
the human element, which was reflected in the complexities of everyday reality and the different perspectives of those engaged in education, was missing from most educational evaluation.

(Worthen \& Sanders, 1987, p. 128)

Evaluation models, aimed at remedying this omission came to be called responsive or participant-oriented evaluation.

Responsive evaluation recognized the importance of involving various stakeholders, that is, individuals and groups with a vested interest in the educational entity and, therefore, in the evaluation process. By involving stakeholders in establishing the evaluative criteria, the problems of meeting the information needs of clients, addressing value issues, and dealing with situational realities could be addressed. Stakeholders might include students, parents, teachers, administrators, community members, and government servants. The democratic orientation of these models placed the information needs of consumers and providers of educational services on an equal level with those of the evaluators, sponsoring agencies, or administrators.

MacDonald $(1974,1976)$, arguing that evaluation was a political enterprise, focused on the ownership of evaluation information. In his analysis, the participants in an educational endeavor had the right of ownership to evaluative information related to that endeavor; therefore, they should set the evaluation agenda including defining issues, objectives, methodology, interpretation, and the 
final distribution of evaluation findings to outside audiences.

More recently Guba and Lincoln (1981, 1989) have expanded on the theoretical underpinnings of participantoriented, responsive evaluation. They believe that effective evaluation must serve the needs of a pluralistic society, empowering all stakeholders by encompassing the perceptions and values of multiple stakeholders. This inclusive approach promotes greater utilization of information gathered and judgments rendered in the evaluation process by all stakeholders.

Guba and Lincoln $(1981,1989)$ argued that nonresponsive/non-participant oriented evaluation fails to adequately address the needs of a pluralistic society. Stakeholders can be abused and oppressed by being eliminated from the information production and reception processes. In their view, all evaluation is about producing and sharing information. Access to and possession of evaluation information is a powerful means by which one group can dominate other groups. In addition, stakeholders who do not feel evaluation information is relevant to their concerns will not use that information. Stakeholder groups who share their perceptions and values act to educate one another. As Guba and Lincoln (1989) pointed out:

the numbers and kinds of claims, concerns, and issues [contemplated in an evaluation] are typically beyond those contemplated by the evaluator him- or herself or by the sponsor, 
founder or other client. claims, concerns, and issues . . arise out of the particular construction(s) that a stakeholder group has formulated, and reflect their particular circumstances, experiences, and values. often the nature of their claims, concerns, and issues is completely unpredictable by anyone not him- or herself a member of the group. (p. 55)

In practice, Guba and Lincoln (1989) stress evaluation should involve identifying the stakeholders who are "at risk" in the evaluation and collecting information from these various stakeholder groups about their "claims, concerns, and issues." Once this information gathering has occurred, evaluation should provide a methodology and a forum through which the "different constructions, claims, concerns, and issues can be understood, critiqued, and taken into account" (pp. 72-73), and be organized in such a way that parties can negotiate items for which a consensus does not exist.

Responsive evaluation has as its ultimate purpose building consensus about an educational program's purposes, goals, and outcomes. Outcomes assessment programs are forms of educational evaluation; as such, the responsive model suggests that research into the points of view held by various constituents about the outcome goals of the program is an essential component of the evaluation process. 
Summary of the Review of the Literature

As the review of the literature illustrates, the need for institutions to develop student outcomes assessment programs is currently quite strong. There are no indications that the pressures to do so are abating. While a few institutions have well-developed outcomes programs and many more have fragments of such programs, nany institutions now are facing the prospect of developing assessment programs for the first time. The problem of identifying appropriate student outcomes for the institution to assess is critical.

Methods for identifying appropriate student outcomes have not been addressed sufficiently in the literature. The conventional wisdom found in "how to" books on assessment encourages the involvement of instructional stakeholders in the identification process; however, they offer only limited and somewhat vague strategies for facilitating this involvement. No research that examined postsecondary teachers' or other instructional stakeholders' attitudes toward specific outcome goals was found in the literature.

Literature in the fields of educational change, organizational development, strategic planning,|and educational evaluation support the need to have stakeholder support for and concurrence with organizational goals. In each discipline, leading scholars emphasize that an 
organization will improve its effectiveness if stakeholders feel a sense of ownership of goals. 
CHAPTER III

\section{DESIGN OF STUDY}

The purpose of the study was to obtain data which would accurately describe the subjects and determine if there were any significant relationships between descriptive data and the subjects' perceptions of the outcome goals that they believed were most important for their students. The subjects were 440 full-time instructors, support staff and instructional administrators employed at Sunrise Community College spring term 1990. This chapter includes sections on: research design, research variables, subjects, response rates, characteristics of respondents, research site, survey instrument, validity, reliability, data gathering procedures, and statistical design.

\section{Research Design}

The research design for this study is a combination of a descriptive study and a causal-comparative study. The study utilized survey research methodology to investigate instructional stakeholders' perceptions related to the importance of student outcome goals. The data examined in this investigation were collected in 1990. Permission to conduct this research was obtained from the President of the 
College. The study was exempted by Portland state University's Human Subjects Review Committee from the review process in January 1990.

The six independent variables are listed and defined below; data for these variables were collected from the biographical items on the student outcome Goals Inventory, a survey instrument developed by the investigator. The primary independent variable investigated in this study was the type of student served by the respondent. The dependent variables consisted of 23 items which comprise the conistructs of the student outcome Goals Inventory.

The descriptive portion of this study investigated Resiearch Questions 1 and 2.

Research Question 1 asked: of the wide array of student outcomes that are perceived by instructional stakeholders to be relevant for students in community colleges, which do instructional stakeholders as a whole perceive to be most important? Research Question 1 can be restated as the following hypothesis (Hypothesis 1): Instructional stakeholders as a whole perceive some of the dependent variables (i.e., the 23 student outcome goals) to be more important than others for the students they serve most often.

Research Question 2 asked: Can the 23 student outcome goals be factored into a smaller number of underlying conistructs or dimensions? Research Question 2 can be 
restated as the following hypothesis (Hypothesis 2): The 23 outcome goal measures represent a smaller number of constructs.

The causal-comparative portion of the study investigated Research Questions 3, 4, and 5a through 5e. A brief discussion of each of these questions and the null hypotheses associated with each question follows.

Research Question 3 asked: Does the perceived importance of student outcomes vary in relationship to the type of students the stakeholder serves most often--that is, professional/technical, lower division collegiate, or developmental? The assumption of this question was that the perception of the importance of the 23 student outcome goals (i.e., the dependent variables) could be mediated by the independent variable, type of student the respondent served most often. This variable was designated the primary independent variable in this investigation. The title of this variable was shortened to "student group served." The values associated with this variable were: (a) professional/technical students, (b) lower division transfer students, (c) developmental education students, and (d) a combination of two or three of the three types of students listed above. The null hypothesis for Research Question 3 was:

Hypothesis 3. There are no significant differences in the mean ratings on the 23 dependent variables (i.e., 
student outcome goals ratings) between stakeholders who served primarily: (a) professional/technical students, (b) lower division transfer students" (c) developmental education students, and (d) a cornbination of the three types of students.

The investigator posed a subordinate question related to Research Question 3, which was Research Question 4. Research Question 4 asked: Is it possible to predict which outcomes are valued most highly be stakeholders based on the type of students they serve? The assumption underlying this question was that the independent variable "student group served" could be predicted by subjects' response to the dependent variable student outcome goals. The hypothesis for Research Question 4 was:

Hypothesis 4. There are no isignificant sets of predictor variables (i.e., student outcome goals) that accurately predict the criterion variable (i.e., type of student served) .

Finally, the investigator posed Research Question 5a through 5e. These questions asked whether the perceived importance of student outcome goals vary in relationship to other stakeholder biographical characteristics; specifically: (a) the type of students the stakeholder serves most often, (b) the stakeholder's professional role, (c) the number of years the stakeholder has worked in a community college, (d) the number of years the stakeholder 
has worked at Sunrise Community college, (e) the campus assignment of the stakeholder, and (f) the stakeholder's gender. The assumption underlying this question was that instructional stakeholders' perceptions of the relative importance of student outcome goals would be mediated by the secondary independent variables stated in the research question. The null hypotheses for $5 \mathrm{a}$ through $5 \mathrm{e}$ were: Hypothesis 5a. There are no significant differences in the mean ratings on the 23 dependent variables (i.e., student outcome goals ratings) between stakeholders who performed the professional roles of teacher, instructional administrator, staff and dual professional roles which combine two of the roles above.

Hypothesis 5b. There are no significant differences in the mean ratings on the 23 dependent variables (i.e., student outcome goals ratings) between stakeholders based on the number of years they worked in a community college.

yypothesis 5c. There are no signiricant diff́erences in the mean ratings on the 23 dependent variables (i.e., student outcome goals ratings) between stakeholders based on the number of years they worked at scC.

Hypothesis 5d. There are no significant differences in the mean ratings on the 23 dependent variables (i.e., student outcome goals ratings) between stakeholders who work primarily at Riverview, Extended Campus, Brooklyn, and Meadowland. 
Hypothesis 5e. There are no significant difference in the mean ratings on the 23 dependent variables (i.e., student outcome goals ratings) between stakeholders who are male and female.

\section{Research Variables}

The independent variables are:

1. Student group served--The student group served variable has three values--students enrolled in technical or professional/technical programs, students enrolled in developmental education (including English as a Second Language, and English as Non-native Language), and students enrolled in lower division transfer courses. subjects are asked to identify which of the three student group values best describes the students with whom they work most often. 2. Professional role--Professional role refers to the type of work subjects perform at the college. This variable has four values: (a) teachers; (b) instructional administrators; (c) support staff who serve as advisors, librarians, and counselors; and (d) dual professional roles which combine two of the roles $a, b$, and $c$ above.

3. Number of years worked in a community college--The number of years subjects have worked in a community college was selected as a variable because longevity in the profession may affect the perceptions related to students, 
4. The number of years worked at ScC--The number of years worked at SCC was selected as a variable because length of service may affect subjects' perceptions related to students.

5. Campus location--SCC has four campuses, each with a distinct environment and student body. The four campuses are Riverview, Meadowland, Brooklyn, and the Extended Campus. Each|campus is described in detail below under the heading Research site. The campus location was selected as a variable because the researcher had observed a pervasive belief on thelpart of instructional stakeholders that each campus had its own unique history and character and that the faculty at any given campus held considerably different beliefs from those at other campuses.

6. Gender--Gender was selected as a variable because it may be associated with perceptions related to goals for students.

The dependent variables consisted of the 23 scaled items on the student Outcome Goals Inventory.

Subjects

The accessible population for the survey consists of all faculty members and instructional administrators. This population included all full-time SCC staff who were identified as lower-division transfer, professional/ technical or developmental education faculty, and 
instructional administrators with responsibilities to administer any of those three areas. Adjunct (part-time) faculty were not included in the target population because they tend to be transient and to have minimal participation in setting academic policy and developing curriculum. The entire population of full-time instructional stakeholders was included as research subjects.

\section{Response Rate}

Questionnaires were distributed to 440 instructional stakeholders assigned to four campuses. A total of 244 were returned, and 241 were usable. The overall response rate was 55\%. Of the six demographic variables used in this study, the gender and campus location of each person surveyed were known to the researcher prior to distributing the questionnaires; consequently, she was able to calculate response rates for these two variables. Response rates at individual campuses ranged from $41.9 \%$ at the smallest campus, The Extended Campus, to $60.4 \%$ at the largest campus, Riverview. Response rates for males and females were almost identical at $54.5 \%$ and $54.6 \%$ respectively. Table 4 displays the number and percentage of responses by campus and gender. 
Table 4

Response Rate of Population Surveyed

by Campus Location and Gender

\begin{tabular}{lrcc}
\hline Variable name & $\begin{array}{c}\text { Number } \\
\text { Surveyed }\end{array}$ & $\begin{array}{c}\text { Number of } \\
\text { Responses }\end{array}$ & $\begin{array}{c}\text { Percent of } \\
\text { Responses }\end{array}$ \\
\hline Campus location & & & \\
Riverview Campus & 48 & 29 & 60.4 \\
Extended Campus & 31 & 13 & 41.9 \\
Meadowland Campus & 71 & 37 & 52.1 \\
Brooklyn Campus & 290 & 160 & 55.2 \\
Missing & 2 & & 54.3 \\
Total for variable & 440 & 239 & \\
& & & 54.6 \\
Gender & & & 54.5 \\
Female & 216 & 118 & \\
Male & 224 & 122 & 54.5 \\
Missing & 440 & 240 & \\
Total for variable & & & \\
\hline
\end{tabular}

The other variables--type of students served, professional role, number of years worked in a community college and number of years worked at scc--were-self reported on the questionnaire; therefore, the exact number for each group was unknown prior to collecting the data, and the response rate could not be calculated for them. 
Characteristics of Respondents

by Independent Variables

Student Groups served by

Respondents

When respondents reported the type of student group

they served most often, $35.3 \%$ reported serving

professional/technical students, while another $34.9 \%$

reported that they served a combination of students (i.e.,

two or more of the groups that included

professional/technical, lower division transfer, and

developmenta]). Twenty-two point four percent of the

respondents reported working primarily with lower division

transfer students, and the smallest proportion, 7.5\%, worked

with developmental education students. Table 5 shows the

number and percentage of respondents who selected each of

the four available values for this variable.

Table 5

Respondents by Student Groups

Served Most often

\begin{tabular}{lcc}
\hline $\begin{array}{l}\text { Type of student } \\
\text { Served Most often }\end{array}$ & $\begin{array}{c}\text { Number of } \\
\text { Respondents }\end{array}$ & $\begin{array}{c}\text { Percent of } \\
\text { Respondents }\end{array}$ \\
\hline Professional/technical & 85 & 35.3 \\
Lower division transfer & 54 & 22.4 \\
Developmental & 18 & 7.5 \\
Two or more of above & 84 & 34.9 \\
Total & 241 & 100.0 \\
\hline
\end{tabular}


Professional Role of

Respondents

When asked on the questionnaire to report their professional role at the college, the majority (65.1\%) reported they were teachers, followed by instructional administrators (12.9\%), and support staff (11.6\%). Ten point four percent reported they performed dual roles, meaning that they performed a combination of teacher, instructional administrator and/or support staff. Table 6 displays the number and percentage of respondents in each role.

Table 6

Respondents by Professional Role

\begin{tabular}{lcc}
\hline Role & $\begin{array}{c}\text { Number of } \\
\text { Respondents }\end{array}$ & $\begin{array}{c}\text { Percent of } \\
\text { Respondents }\end{array}$ \\
\hline Teacher & 157 & 65.1 \\
Instr admin & 31 & 12.9 \\
Support staff & 28 & 11.6 \\
Other & 25 & 10.4 \\
Total & $239 *$ & 100.0 \\
*Missing observations $=2$ &
\end{tabular}

The researcher used only three professional role groups in the analysis of variance--teachers, instructional administrators and support staff--eliminating the group called "other" which represented individuals who reported working in roles other than the first three. Table 7 
displays the number and percentages of respondents in the three remaining groups.

Table 7

Respondents Not in Dual or Other Professional Roles

\begin{tabular}{lcc}
\hline Role & $\begin{array}{c}\text { Number of } \\
\text { Respondents }\end{array}$ & $\begin{array}{c}\text { Percent of } \\
\text { Respondents }\end{array}$ \\
\hline Teacher & 157 & 72.7 \\
Instr admin & 31 & 14.4 \\
Support staff & 28 & 12.9 \\
Total & 216 & 100.0 \\
\hline
\end{tabular}

Number of Years Worked in

Community Colleges

Respondents were asked on the questionnaire to report the number of years they had worked in a community college. Responses ranged from 1 to 28 years. The mean number of years working in a|community college was 13.99 years. The median was 14 years. Table 8 shows the distribution of years teaching and the frequency of respondents reporting in each category. 
Table 8

Respondents by Number of Years Worked

in Community Colleges

\begin{tabular}{cccc}
\hline $\begin{array}{l}\text { Number of } \\
\text { Respondents }\end{array}$ & $\begin{array}{c}\text { Number of } \\
\text { Years Worked }\end{array}$ & $\begin{array}{c}\text { Number of } \\
\text { Respondents }\end{array}$ & $\begin{array}{c}\text { Number of } \\
\text { Years Worked }\end{array}$ \\
\hline 1 & 4 & 15 & 19 \\
2 & 8 & 16 & 14 \\
3 & 3 & 17 & 14 \\
4 & 5 & 18 & 8 \\
5 & 8 & 19 & 11 \\
6 & 5 & 20 & 13 \\
7 & 9 & 21 & 4 \\
8 & 8 & 22 & 7 \\
9 & 9 & 23 & 5 \\
10 & 19 & 25 & 3 \\
11 & 6 & 26 & 2 \\
12 & 13 & 27 & 1 \\
13 & 11 & 28 & $239 *$ \\
14 & 14 & & \\
Total & & & \\
\hline *issing observations & & & \\
\hline
\end{tabular}

In order to utilize the data related to the number of years worked in a community college in an analysis of variance, the variable was recoded as nominal data using the following categories: (a) 10 years or less, (b) 11 to 20 years, and (c) 21 or more years. When this recoding was performed, the majority of respondents, 51.5\%, had worked from 11 to 20 years, followed by those who had worked 10 or less (32.6\%), and those who had worked 21 or more years (15.98). Table 9 displays the recoded data. 
Table 9

Number of Years Respondents Worked in Community Colleges by Category

\begin{tabular}{lcc}
\hline $\begin{array}{l}\text { Number of } \\
\text { Years }\end{array}$ & $\begin{array}{c}\text { Number of } \\
\text { Respondents }\end{array}$ & $\begin{array}{r}\text { Percent of } \\
\text { Respondents }\end{array}$ \\
\hline 10 or less & 78 & 32.6 \\
11 to 20 & 123 & 51.5 \\
21 or more & 38 & 15.9 \\
Total & $239 *$ & 100.0
\end{tabular}

*Missing observations $=2$

Number of Years Worked at

Sunrise Community College

Respondents were asked on the questionnaire to report the number of years they had worked at sunrise community College. Responses ranged from 1 to 28 years. The mean number of years working at sunrise community college was 12.9 years. The median was 13 years. Table 10 shows the distribution of years teaching at SCC and the frequency of respondents reporting in each category.

It is noteworthy that the mean for number of years worked in any community college $(\underline{\underline{M}}=13.99)$ and the number of years worked at $\operatorname{scC}(\underline{M}=12.9)$ differed by only 1.09 years, indicating that on average the instructional stakeholders at SCC have worked almost their entire community college careers at this single institution. 
Table 10

Respondents by Number of Years

Worked at SCC

\begin{tabular}{crcc}
$\begin{array}{c}\text { Number of } \\
\text { Years Working }\end{array}$ & $\begin{array}{c}\text { Number of } \\
\text { Respondents }\end{array}$ & $\begin{array}{c}\text { Number of } \\
\text { Years Working }\end{array}$ & $\begin{array}{c}\text { Number of } \\
\text { Respondents }\end{array}$ \\
\hline 1 & 8 & 15 & 17 \\
2 & 14 & 16 & 11 \\
3 & 7 & 17 & 9 \\
4 & 7 & 18 & 8 \\
5 & 14 & 19 & 13 \\
6 & 4 & 20 & 5 \\
7 & 9 & 21 & 9 \\
8 & 10 & 22 & 7 \\
9 & 10 & 24 & 6 \\
10 & 15 & 25 & 3 \\
11 & 5 & 26 & 1 \\
12 & 11 & 27 & 1 \\
13 & 7 & 28 & $239 *$ \\
14 & 14 & & \\
& & Total & \\
\hline
\end{tabular}

kMissing observations $=2$

In order to utilize the data related to the number of years worked at Sunrise community college in an analysis of variance, the variable was recoded as nominal data using the following categories: (a) 10 years or less, (b) 11 to 20 years, and (c) 21 or more years. When this recoding was performed, the majority of respondents had worked from 11 to 20 years $(41.0 \%)$, followed by those who had worked 10 or less (43.5.6\%), and those who had worked 21 or more years (15.5\%). Table 11 displays the recoded data. 
Table 11

Number of Years Respondents

Worked at SCC by Category

\begin{tabular}{lcc}
\hline $\begin{array}{l}\text { Number of } \\
\text { Years }\end{array}$ & $\begin{array}{c}\text { Number of } \\
\text { Respondents }\end{array}$ & $\begin{array}{c}\text { Percent of } \\
\text { Respondents }\end{array}$ \\
\hline 10 or less & 98 & 41.0 \\
11 to 20 & 104 & 43.5 \\
21 or more & 37 & 15.5 \\
Total & $239 *$ & 100.0 \\
Missing observations $=2$ & &
\end{tabular}

Campus Location of Respondents

of the 241 respondents, 239 reported their campus location. When sorted by campus, instructional stakeholders at Brooklyn Campus comprised the majority of respondents (66.9\%). The combined number of respondents from the three other campuses made up $32 \%$ of all respondents. Table 12 displays the number of respondents from each campus and the percentage of the total respondents each number represents.

\section{Gender of Respondents}

When asked to report their gender on the questionnaire, $50.8 \%$ of respondents reported they were male and $49.2 \%$ reported they were female. Table 13 displays the breakdown of respondents by gender. 
Table 12

Respondents by Campus

\begin{tabular}{lcc}
\hline Campus & $\begin{array}{c}\text { Number of } \\
\text { Respondents }\end{array}$ & $\begin{array}{c}\text { Percent of } \\
\text { Respondents }\end{array}$ \\
\hline Riverview & 29 & 12.1 \\
Extended Campus & 13 & 5.4 \\
Meadowland & 37 & 15.5 \\
Brooklyn & 160 & 66.9 \\
Total & $239 *$ & 100.0 \\
*Missing observations $=2$ &
\end{tabular}

Table 13

Gender of Respondents

\begin{tabular}{|c|c|c|c|}
\hline Gender & । & $\begin{array}{l}\text { Number of } \\
\text { Respondents }\end{array}$ & $\begin{array}{r}\text { Percent of } \\
\text { Respondents }\end{array}$ \\
\hline $\begin{array}{l}\text { Male } \\
\text { Female }\end{array}$ & $\begin{array}{l}1 \\
1\end{array}$ & $\begin{array}{l}122 \\
118\end{array}$ & $\begin{array}{l}50.8 \\
49.2\end{array}$ \\
\hline Total & 1 & 240 * & 100.0 \\
\hline
\end{tabular}

\section{Research Site}

Sunrise Community college is typical of many large, urban community colleges across the country in that its mission is broad and its student body diverse. scc's mission statement expresses four distinct purposes: to offer "lower|division college transfer programs, occupational, and technical programs, basic skills education, 
and community education programs" (Sunrise Community College [SCC], 1991a, p. 4). This mission is primarily realized through offering courses in a variety of formats at a variety of sites within its district.

Sunrise community college is a two-year public institution, governed by the seven members of the elected Board of Directors. The overall management is centralized with a President and two Vice Presidents (Educational Services and Administrative Services). Many aspects of the college's management are decentralized. Each campus is administered by an Executive Dean who serves many presidential functions for his or her campus and who supervises the campus' instructional activities among other operations. In 1990, SCC employed 369 full-time faculty, 1058 part-time faculty, 115 managers, and 86 professional support staff (which included advisors, cooperative education specialists, and others).

SCC consistz of four geographically distinct campuses, each of which has a different mix of programs and students. The population in 1990 of the Sunrise district was 817,699 . In 1990, of the district population, $11 \%$ of the college age population was enrolled in credit and noncredit classes (5\% were in credit courses) at SCC. The college offered 53 associate degrees and 62 one- and two-year certificates. In 1990, 983 students received associate degrees, and 329 earned certificates. The college offers students a Block 
Transfer option which guarantees students that courses taken in the block structure will be honored by transfer institutions in the state System of Higher Education (SCC, 1991b). The basic and developmental skills programs and the community education programs do not offer credit that can be used to satisfy certificate or degree program requirements. Table 14 shows the number of students in 1990-1991 who engaged in programs in each of the four mission areas--lower division college transfer, professional/technical, developmental, and community education.

Table 14

SCC Student Headcount by Mission Area in 1990-1991

Lower division transfer Professional/technical education Developmental education Community education/other

Total
20,583

36,498

9,745

23,078

89,904

Source: Sunríse Community College (1991b)! Factbook.

The college's programs are offered at a variety of sites. SCC operates four primary facilities: Riverview Campus, Extended Campus, Meadowland Campus, and Brooklyn Campus. Table 15 shows the number of full-time equivalency students enrolled at each of these sites during both years that delimit the study. 
Table 15

SCC student FTE by Campus in 1990-1991

\begin{tabular}{lc}
\hline Campus & Number \\
\hline Brooklyn & 7,337 \\
Riverview & 1,432 \\
Meadowland & 2,153 \\
Extended Campus & 2,930 \\
Total & 13,852 \\
\hline
\end{tabular}

Source: Sunrise Community College (1991b) - Factbook.

Description of Campuses

Sunrise community college is located in a northwestern state. The SCC service district includes part or all of five counties. The campuses are located in or near the state's largest city, a vibrant and rapidly growing municipality, with a population of 438,802 in 1990 . Riverview Campus, the smallest campus in terms of number of students, is located in an inner-city neighborhood that is one of the oldest areas in the city. The 20 block radius around the campus has the highest proportion of ethnic minorities, primarily African-American, in the city. The programs offered on this campus include college transfer, professional/technical, and developmental education.

The Extended Campus centers its activities at two sites--Johanna center in the city's downtown core and West center, approximately 10 miles from the downtown core. The 
Extended Campus also operates an on-site center at a large electronics research and manufacturing company, offering courses to company employees and non-employees. In addition to these primary sites, the Extended Campus offers courses at approximately 200 other locations throughout the district. The majority of these courses are not credit bearing; they are community education or non-credit classes customized to meet community and business needs.

Meadowland Campus is located approximately fifteen miles east of the downtown core. It is situated on 256 acres and is surrounded by agricultural land. The county in which it is located has a high number of Hispanic residents, many of whom are agricultural workers. Despite the agrarian nature of the campus' immediate neighbors, it is located in an area with a high density of companies involved in high technology research, development, and production. Meadowland Campus also offers lower division transfer, professional/technical, developmental, and adult basic education programs.

Brooklyn Campus, the largest of the four campuses in terms of students, is located seven miles from the downtown core in a suburban neighborhood. It enrolls the largest number of ethnic minority students of the four campuses. It serves a total of 23,000 students per year, offering lower division transfer, professional/technical education and developmental education. 
The three comprehensive campuses (Riverview, Meadowland, and Brooklyn) offer a basic array of lower division transfer and developmental education programs with Brooklyn, the largest, providing more variety in lower division and developmental offerings than the other campuses. Few professional/technical programs are duplicated from one campus to the next.

\section{Survey Instrument}

While the research literature on student outcomes assessment has reached critical mass in recent years, a search of the literature revealed that no instrument existed which could be used to measure individuals' attitudes regarding the value of specific student learning and development outcomes; therefore, it was necessary for the researcher to develop an instrument.

\section{Construction of the Survey}

\section{Instrument}

The survey questionnaire was developed following the principles outlined by suskie (1989) in Questionnaire survey Research. The survey questionnaire is composed of three parts. The first part collected demographic data which was used to group respondents into the subgroups based on the variables to be analyzed. The second part focused on attitudes toward student outcomes and consisted of an inventory of 23 student outcomes which were presented as 
goal statements and were linked to a four point Likert-like scale. The procedure for identifying|these goal statements is described below. This set of items represents a unidimensional scale, and the dimension of focus is student learning and development outcomes. For each goal statement, recipients were asked to select one of four values (from not very important to very important) which reflected their perception of the importance of the outcome to the students whom they served most often. Each section was preceded by clear directions for completing the questionnaire.

The item pool included in the instrument's list of outcome goals was developed using a focus group methodology which is described in detail in the validity section below. The instrument may be found in Appendix $A$.

\section{Validity}

In order to identify outcomes which had content validity and could be included in the item pooI, the investigator utilized focus group research to create an inventory of student outcomes, She conducted seven focus groups, involving 57 faculty and administrators. This sample of staff was drawn using a stratified sampling method. The sample was drawn from a list provided by Sunrise Community college. Stratification was based on campus location (Riverview, Extended Campus, Meadowland and Brooklyn), role of stakeholder (instructor, support staff or 
administrator), and educational discipline of stakeholder (professional/technical, lower division transfer, or developmental education instructor). The researcher served as focus group facilitator and employed a questioning script to engage this cross-section of stakeholders in discussions of the student learning and development outcomes that they believed were most important for the students with whom they worked most often. Responses were recorded on flip chart by the facilitator and in text form by a notetaker provided by the college.

The focus groups were conducted using the methodology recommended by Morgan (1988, p. 49) in Focus Groups as Qualitative Research. Groups were composed of from 7 to 10 people. In most groups, participants were grouped homogeneously; that is, teachers, support staff and administrators were clustered separately in groups. One heterogeneous group was held which contained a mixture of teachers and administrators from diverse disciplines. This mixed group was conducted to explore the possibility that the interaction among participants in a mixed group might generate different responses from those found in non-mixed groups. Responses from the heterogenous group did not differ appreciably from the homogeneous groups. Moderator involvement was low to prevent the biases of the moderator from influencing participants and, consequently, "reproducing" these biases in the data. 
Responses were documented using a tape recorder and typed summaries of transcriptions. The investigator conducted a content analysis to determine the frequency of each referential unit. These referential units were organized into sets of behavioral, attitudinal, and cognitive outcomes. These, in turn, formed the basis for constructing the items included in the instrument.

Once the initial item pool was created, the researcher eliminated all items which were only referred to once in the focus groups. This process reduced the initial pool from 38 items to 23. The researcher compared the item pool to the student outcomes referred to in the literature section of this report to insure that none of the student outcomes represented in the literature had been left out in the focus group process. In fact, none had been. The 23 items were reviewed by a panel consisting of eleven instructional stakeholders who judged the suitability of the wording used for each iter. They provided feedback on factors such as clarity, length, sufficiency, and interest level of the language used in each item.

This instrument development process was replicated at two other community colleges. The researcher replicated the process in the state's second largest community college, and a colleague replicated the process at a small community college in another state. At each of the three sites, the items identified through the focus group process were 
similar in content and wording, but were not identical. Variations in the item pools generated at these three sites is expected and attributable to differences in institutional size and context.

The use of focus groups to develop items for survey questionnaires is supported by Krueger (1988), Morgan (1988), and stewart and Shamdasani (1990). The latter find focus groups valuable tools for

learning how respondents talk about the phenomenon of interest [which] in turn may facilitate the design of questionnaires . . . that can be employed in more quantitative research. (p. 114)

Morgan advocates the use of focus groups to develop item pools for questionnaires because focus groups can provide "evidence of how the respondents typically talk about the topic in question . . [and] ensure that the researcher has as complete a picture of participants' thinking as possible" (p. 34). The reliance on what he terms "armchair" generation of items or "borrowing" items from existing instruments may omit important items which results in an invalid measure (p. 33).

Scriven (1967), in his work on researching values, made a similar recommendation. Discussing the need to ground value statements in field studies in the local context, he asserted that an experienced researcher:

may be able to generate, a priori hypotheses about the value positions in a given setting, [but] in most cases [she] will want, at the very least to check [her] hypotheses, if not generate them de novo, by close study of and interaction with the 
context itself, especially with the people who inhabit it. (p. 45)

Cronbach (1982) believed that the process of developing evaluative questions should entail two phases. The first phase, the divergent phase, involves generating as many questions as possible, a laundry list of items which are elicited from as many sources as possible. This brainstorming stage continues until it appears that no significantly different or new questions are being generated. The second phase, the convergent phase, consists of winnowing and narrowing the questions until the appropriate ones are selected. Using focus groups to generate the item pool for this instrument conforms with the divergent phase. The convergent phase corresponds to the process used by this researcher in eliminating any items which were mentioned only once in the focus groups.

The instrument was pilot tested by a group of $10 \mathrm{sCC}$ instructional stakeholders, including six instructors, one member of the support staff, and three administrators. The researcher administered the questionnaire to the test group who critiqued it for understandability, wording, and format.

$$
\text { Reliability }
$$

To test the reliability of the scaled portion of the questionnaire (the scale of 23 items, utilizing a 4-point Likert format), the researcher performed a statistical test, coefficient alpha, on the data. The coefficient alpha 
estimates reliability based upon the inter-item correlation matrix. In effect, this is a test for internal consistency. The SPSS subprogram RELIABILITY was used. The resulting item-total coefficients and the coefficient of reliability are shown in Table 16. The sPSS program computes two reliability coefficients for alpha, Chronbach's "a" and standardized "a." The coefficient alpha was 0.8197 , an acceptable level of reliability.

Table 16

Coefficients of Correlation and coefficient Alpha for the student outcome Goals Inventory

\begin{tabular}{lc}
\hline Item & Item-Total Correlations \\
\hline 1 & 0.3467 \\
2 & 0.3238 \\
3 & 0.3864 \\
5 & 0.3545 \\
6 & 0.4421 \\
7 & 0.4421 \\
8 & 0.4336 \\
9 & 0.2357 \\
10 & 0.3541 \\
11 & 0.3632 \\
12 & 0.2518 \\
13 & 0.2405 \\
14 & 0.2549 \\
15 & 0.4335 \\
14 & 0.2686 \\
16 & 0.2259 \\
17 & 0.3468 \\
18 & 0.5148 \\
19 & 0.4858 \\
20 & 0.5535 \\
21 & 0.4179 \\
22 & 0.3899 \\
23 & 0.4316 \\
& 0.3258 \\
\hline
\end{tabular}


Data Gathering Procedures

The investigator presented a proposal of the study to the President of sunrise community college who was asked to endorse it. A cover letter was signed by the President (see Appendix A). January 1990, the Portland State University Protection of Human Subjects Committee exempted the proposed study from review.

The questionnaires, along with the cover letter, which explained the purpose of the study, were sent by campus mail to all full-time faculty, support staff, and instructional administrators at all four campuses. Addressed campus mail envelopes were included to facilitate the return of the questionnaires. Questionnaires were returned to scC's Office of Institutional Research. Respondents were not asked for their names, and anonymity was assured in the cover letter. Follow-up notices were mailed to all recipients, and notices were included in the college staff bulletin and the staff federation newsletter (published by the union) reminding recipients to complete and return the questionnaire.

The questionnaires were distributed in February 1990. Table 17 displays the number and percentage of questionnaire packets sent out broken down by campus and gender. 
Table 17

Distribution of Survey Questionnaires

by Campus Location and Gender

\begin{tabular}{lcr}
\hline Variable Name & Number & Percent \\
\hline Campus location & & \\
Riverview Campus & 48 & 11 \\
Extended Campus & 31 & 7 \\
Meadowland Campus & 71 & 16 \\
Brooklyn Campus & 290 & 66 \\
Total & 440 & 100 \\
Gender & & 49 \\
Female & 216 & 51 \\
Male & 224 & 100 \\
Total & 440 & \\
\hline
\end{tabular}

Statistical Design

The statistical design for this study included the use of descriptive and inferential statistics. The application of each of these statistics to the research questions and the related hypotheses is described below.

Hypothesis 1. Instructional stakeholders as a whole perceive some of the dependent variables (i.e., the 23 student outcome goals) to be more important than others for the students they serve most often.

To test research Hypothesis 1, the researcher used descriptive statistical methods including frequencies, means as measures of central tendencies, standard deviations, ranges, and percentages. The SPSS subprogram DESCRIPTIVES was performed to derive these statistics. 
Hypothesis 2. The 23 outcome goals measures represent a limited number of constructs that are inter-related. To test this propasition the researcher submitted the data from the outcome goals measures to a factor analysis. The sPSS subprogram FACTOR was used to determine whether factors could be identified for the 23 outcomes variables.

Hypothesis 3. There are no significant differences in the mean ratings on the 23 dependent variables (i.e., student outcome goals ratings) between stakeholders who served primarily: (a) professional/technical students, (b) lower division transfer students, (c) developmental education students, and (d) a combination of the three types of students.

In order to test Hypothesis 3, the dependent variables were analyzed using a univariate, one-way analysis of variance design with the alpha level set at .05. The spss subprogram ONEWAY and the Scheffé multiple comparison procedure were performed to determine whether significant differences existed $\mid$ among the subgroups identified for the study. The Scheffé/test is required because a significant $F$ value has limited power to determine the equality of means, indicating only that the means are probably not all equal. To confidently reject the null hypothesis a multiple comparison procedures test is necessary. The researcher selected the scheffe because it is a conservative test for equality of means (Norusis, 1992). Any instance in which 
the Scheffe did not find a significant difference between means was treated as having confirmed the null hypothesis. Failure to find significant differences does not conclusively indicate that the means are, in fact, equal. It does, however, decrease confidence that the results of the ANOVA reflect true differences in subgroup means.

Hypothesis 4. There are no significant sets of predictor variables (i.e., student outcome goals) that accurately predict the criterion variable (i.e., type of student served).

In order to test Hypothesis 4 the statistical test discriminant function analysis was performed. The purpose of this test was to determine whether a set of common predictor variables (i.e., the 23 student outcome goals) could predict the subgroups that comprise the criterion variable "type of student served" with a high percentage of accuracy. The SPSS subprogram DISCRIMINANT was performed to derive these statistics.

Hypothesis 5a. There are no significant differences in the mean ratings on the 23 dependent variables (i.e., student outcome goals ratings) between stakeholders who performed the professional roles of teacher, instructional administrator, and support staff.

Hypothesis 5b. There are no significant differences in the mean ratings on the 23 dependent variables (i.e., 
student outcome goals ratings) between stakeholders based on the number of years they worked in a community college.

Hypothesis 5c. There are no significant differences in the mean ratings on the 23 dependent variables (i.e., student outcome goals ratings) between stakeholders based on the number of years they worked at scc.

Hypothesis 5d. There are no significant differences in the mean ratings on the 23 dependent variables (i.e., student outcome goals ratings) between stakeholders who worked primarily at Riverview, Extended Campus, Brooklyn, and Meadowland.

Hypothesis 5e. There are no significant difference in the mean ratings on the 23 dependent variables (i.e., student outcome goals ratings) between stakeholders who were male and female.

In order to test each of the Hypotheses $5 \mathrm{a}$ through $5 \mathrm{~d}$, the 23 dependent variables (i.e., the student outcome goals) were analyzed using a univariate, one-way analysis of variance design with the alpha level set at .05. The spss subprogram ONEWAY F-ratio, and Scheffe multiple comparison test were performed to determine whether significant differences existed among the subgroups identified for study.

In order to test Hypothesis 5e, the 23 dependent variables were analyzed using a two-tailed $t$ test with the 
In order to test Hypothesis $5 e$, the 23 dependent variables were analyzed using a two-tailed $\underline{t}$ test with the alpha level set at .05. The SPSS subprogram I TEST was used for this procedure.

All analyses were performed using the statistical Program for the Social sciences 5.0 [computer program] (1992). Missing data were treated as missing in the analysis and were not included when reporting the total number of responses to an item. 
CHAPTER IV

RESULTS

Introduction

This chapter describes the results of the statistical analyses of the information obtained by administering the Student outcome Goals Inventory Questionnaire and discusses the findings related to each of the research questions. The following sections are organized in order of the research questions with each research question serving as a freestanding subdivision title.

1. Of the wide array of student outcomes that are perceived by instructional stakeholders to be relevant for students in community colleges, which do instructional stakeholders as a whole perceive to be most important?

2. Can the 23 student outcome goals be factored into a smaller number of underlying constructs or dimensions?

3. Does the perceived importance of student outcomes vary in relationship to the type of students the stakeholder serves most often--that is, professional/technical, lower division transfer, or developmental?

4. Is it possible to predict which outcomes are valued most highly be stakeholders based on the type of students they serve? 
5a-5e. Does the perceived importance of student outcome goals vary in relationship to other stakeholder biographical characteristics, specifically, the stakeholders': (a) professional role (instructor, support staff, or administrator), (b) number of years worked at a community college, (c) number of years worked at scc, (d) the campus assignment of the stakeholder (Riverway Campus, The Extended Campus, Meadowland Campus, or Brooklyn Campus), and (e) gender?

\section{Findings}

In order to investigate the research questions, the researcher administered the student outcome Goals Inventory Questionnaire to 440 instructional stakeholders at Sunrise Community College. A total of 241 (55\%) usable questionnaires were returned. The data collected from these questionnaires were used in a variety of statistical procedures chosen to investigate and answer the research questions.

Both descriptive and inferential statistics were used to analyze the data. Descriptive statistics, including the frequencies, ranges, standard deviations, and means were calculated for the outcome goals variables. In addition, a factor analysis was performed on this data. Four inferential statistics were used to investigate relationships. Univariate one-way analysis of variance was 
performed using six of the seven biographical

characteristics as the independent variables and the outcome goals measures as the dependent variables. For the biographical variable "gender" a $t$ test was employed with "gender" as the independent variable and the outcome goal measures as the dependent variable. In addition to the statistical procedures described above, a multivariate discriminate function analysis was performed using the outcome goal measures as the independent variables and the biographical variable "type of student served" as the dependent variable.

Table 18 summarizes the significant relationships produced by the ANOVAs and the $t$ test for all of the outcome goal variables.

\section{Research Question 1}

of the wide array of student outcomes that are perceived by instructional stakeholders to be relevant for students in community colleges, which do instructional stakeholders as a whole perceive to be most important?

Hypothesis 1. Research Question 1 above was restated as Hypothesis 1, "Instructional stakeholders as a whole perceive some of the dependent variables (i.e., the 23 student outcome goals) to be more important than others for the students they serve most often." This section presents the results of the descriptive statistics employed to support or reject the proposition. 
Table 18

Summary of the Dependent Variables for which ANOVAs and $t$ test Found statistically Significant Differences

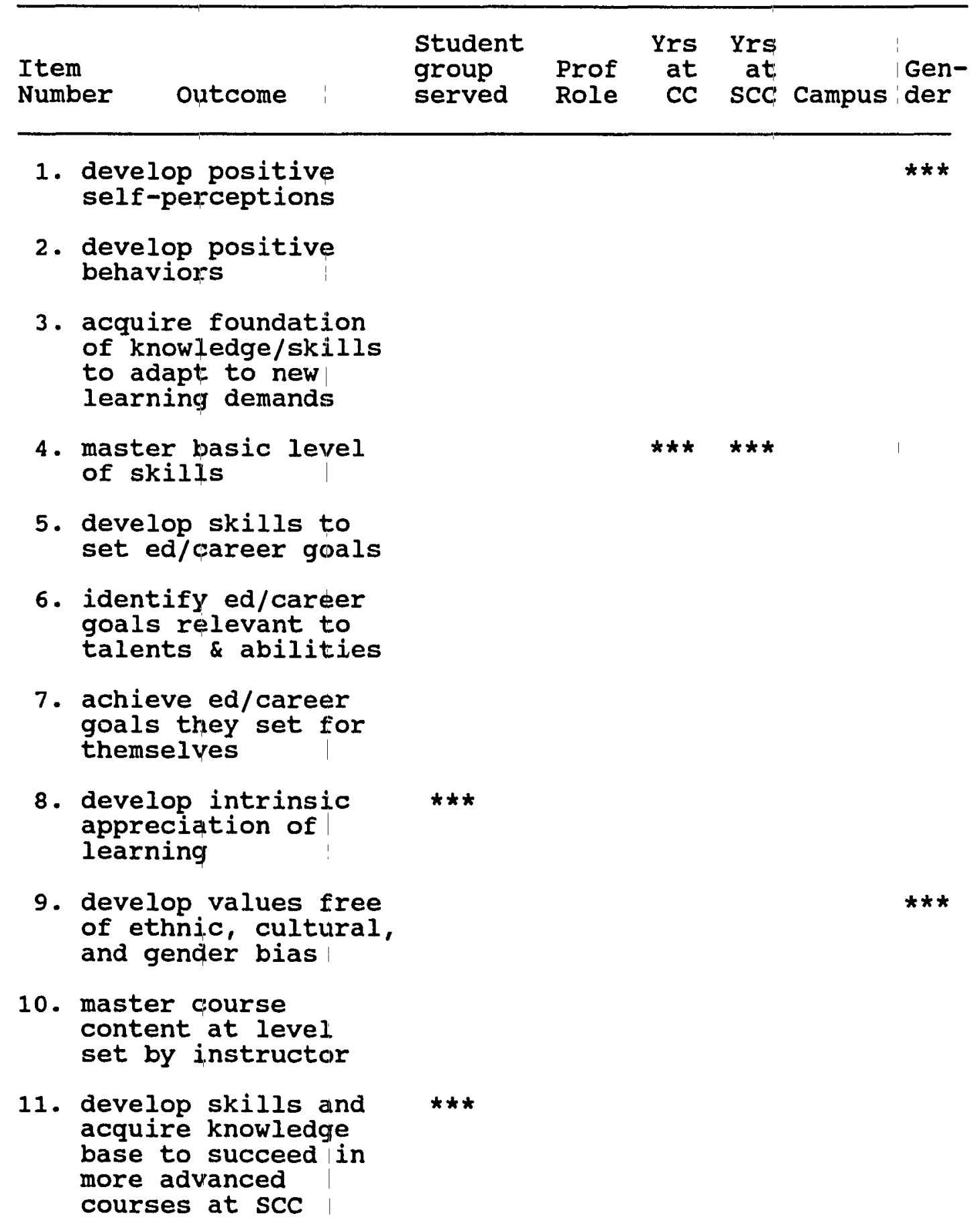


Table 18

Summary of the Dependent Variables for which ANOVAs and $t$ test Found statistically significant Differences (Continued)

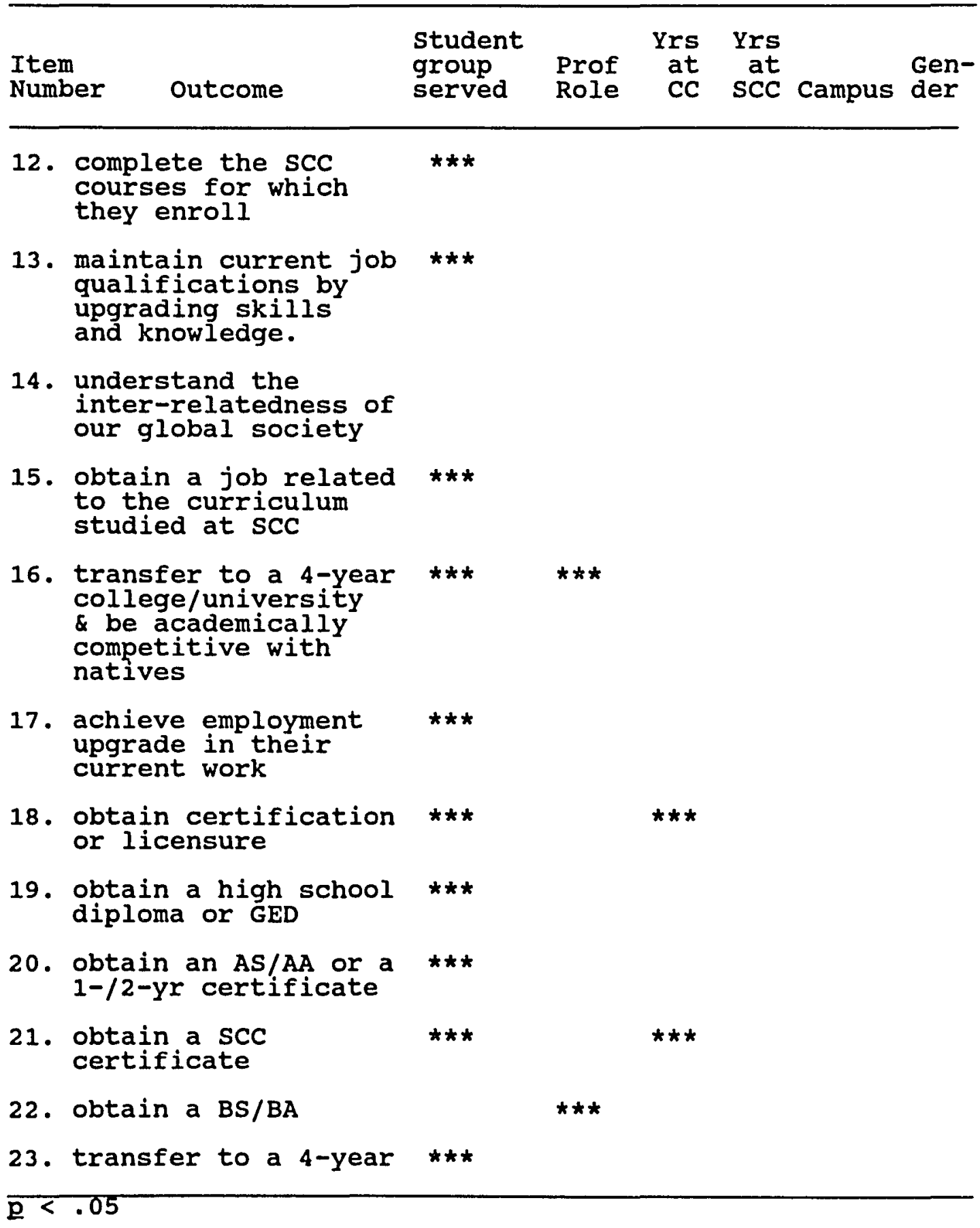


In order to address this question, the mean for each of the outcome goals (i.e., the dependent variables) was examined. The means ranged from 2.49 to 3.79 , thus confirming the proposition that instructional stakeholders as a whole perceive some outcome goals to be more important than others. Fifteen of the outcomes were rated moderately important or better $(>3.00)$. Eight of the items were rated less than moderately important $(<3.00)$. It is important to note that none of the outcomes was rated by the group as not important. Standard deviations for the 23 items ranged from .49 to 1.10 ; therefore, the standard deviations among items differed considerably.

It is notable that the standard deviations of the top ranked items $(\geq 3.00)$ ranged from .49 to 1.67 . This relatively small standard deviation suggests that a general consensus exists among faculty as to the outcomes they perceive to be most important for students.

Examination of the ranked means revealed that the outcomes perceived to be most important by the respondents as a whole (that is, the mean was 3.50 or more) tended to be affective in nature, behaviors related to a positive affect, or outcomes related to basic skill development. Specifically, these highest rated outcomes were: (a) students develop positive perceptions of themselves, such as, self-esteem and self-confidence $(\underline{M}=3.79) ;(b)$ students develop positive behaviors, such as, initiative, honesty, 
and self-discipline $(\underline{M}=3.75) ;(c)$ students acquire a foundation of knowledge and skills that help them adapt to new learning demands $(\underline{M}=3.73) ;(d)$ students master basic skills $(\underline{M}=3.67)$; (e) students develop skills to set educational goals $(\underline{M}=3.63)$; (f) students identify educational goals $(\underline{M}=3.60)$; and $(g)$ students achieve educational goals they have set for themselves $(\underline{M}=3.51)$. Outcomes perceived to be least important (less than 3.00 or less than moderately important) by the group as a whole tended to be more traditional measures of student success. Listed in ascending order by mean, these were: (a) students transfer to a four-year college or university $(\underline{M}=2.49) ;(b)$ students obtain a baccalaureate degree or higher $(\underline{M}=2.50)$; (c) students obtain a 1- or 2-year certificate $(\underline{M}=2.58)$; (d) students obtain an associate degree $(\underline{M}=2.76)$; (e) students obtain a high school diploma or GED $(\underline{M}=2.79)$; (f) students obtain certification or licensure in their profession $(\underline{M}=2.88) ;(g)$ students achieve employment upgrade $(\underline{M}=2.92) ;(h)$ students transfer to a four-year college or university and are academically competitive with the transfer institution's native students $(\underline{M}=2.94)$. These lower rated outcomes were associated with employment and baccalaureate degree seeking outcomes.

In Table 19, the dependent variables are ranked by mean in descending order and displayed with the number of respondents, the standard deviations and ranges. In all 
subsequent tables all items are numbered according to their rank order in the above table of descending means, not according to their number on the questionnaire.

Table 19

Means, Standard Deviations, and Ranges for All Respondents on the student outcome Goals Variables

$$
\underline{N}=241
$$

\begin{tabular}{|c|c|c|c|c|c|}
\hline Rank & $\begin{array}{l}\text { outcome Goal } \\
\text { for students }\end{array}$ & Number & Mean & SD & Range \\
\hline 1. & $\begin{array}{l}\text { develop positive } \\
\text { perceptions of themselves }\end{array}$ & 238 & 3.79 & .49 & $2-4$ \\
\hline 2 . & develop positive behaviors & 239 & 3.75 & .54 & $1-4$ \\
\hline 3. & $\begin{array}{l}\text { acquire a foundation of } \\
\text { knowledge/skills that } \\
\text { helps them adapt to } \\
\text { new learning demands }\end{array}$ & 238 & 3.73 & .51 & $2-4$ \\
\hline 4. & $\begin{array}{l}\text { master a basic level } \\
\text { of skills in } \\
\text { reading, writing, math, } \\
\text { and language proficiency }\end{array}$ & 238 & 3.67 & .65 & $1-4$ \\
\hline 5. & $\begin{array}{l}\text { develop the skills to set } \\
\text { educational/career goals } \\
\text { for themselves }\end{array}$ & 240 & 3.63 & .65 & $1-4$ \\
\hline 6. & $\begin{array}{l}\text { identify educational/career } \\
\text { goals relevant to their } \\
\text { talents and abilities }\end{array}$ & 239 & 3.60 & .67 & $1-4$ \\
\hline 7. & $\begin{array}{l}\text { achieve educational goals } \\
\text { they set for themselves }\end{array}$ & 241 & 3.51 & .65 & $1-4$ \\
\hline 8 . & $\begin{array}{l}\text { develop an intrinsic } \\
\text { appreciation of learning }\end{array}$ & 237 & 3.45 & .69 & $1-4$ \\
\hline 9. & $\begin{array}{l}\text { develop values free } \\
\text { of ethnic, cultural, } \\
\text { and gender bias }\end{array}$ & 236 & 3.39 & .81 & $1-4$ \\
\hline
\end{tabular}


Table 19

Means, Standard Deviations, and Ranges for All Respondents on the student Outcome Goals Variables

$\underline{N}=241$

(Continued)

Rank for Students $\begin{aligned} & \text { Outcome Goal } \\ & \text { for Number Mean SD Range }\end{aligned}$

10. master course content at

a level set by the

instructor (s)

$238 \quad 3.38 \quad .60 \quad 2-4$

11. develop the skills and acquire the knowledge base to succeed in more advanced courses at SCC

$\begin{array}{llll}238 & 3.27 & .79 & 1-4\end{array}$

12. complete the scc courses for which they enroll

$239 \quad 3.21 \quad .76 \quad 1-4$

13. maintain qualifications for the job they now hold by upgrading skills/knowl

$240 \quad 3.15 \quad .90 \quad 1-4$

14. understand the inter$\begin{array}{llllll}\text { relatedness of global society } & 238 & 3.03 & .92 & 1-4\end{array}$

15. obtain a job related to the curriculum they studied at SCC

$240 \quad 3.03 \quad .85 \quad 1-4$

16. transfer to a 4-year college or university and are academically competitive with natives

$232 \quad 2.94 \quad 1.10 \quad 1-4$

17. achieve employment upgrade in their current field of work

$\begin{array}{llll}240 & 2.92 \quad .88 & 1-4\end{array}$

18. obtain certification or licensure in their profession

$\begin{array}{llll}236 & 2.88 & .99 & 1-4\end{array}$

19. obtain a high school

diploma or GED

$\begin{array}{llll}232 & 2.79 & .95 & 1-4\end{array}$


Table 19

Means, Standard Deviations, and Ranges for All Respondents on the student outcome Goals Variables $\underline{\mathrm{N}}=241$

(Continued)

\begin{tabular}{|c|c|c|c|c|c|}
\hline Rank & $\begin{array}{l}\text { Outcome Goal } \\
\text { for students }\end{array}$ & Number & Mean & SD & Range \\
\hline 20 & $\begin{array}{l}\text { obtain an AS/AA or a } \\
1 \text { - or } 2 \text {-year certificate }\end{array}$ & 236 & 2.76 & .89 & $1-4$ \\
\hline 21 & obtain a scC certificate & 235 & 2.58 & .91 & $1-4$ \\
\hline 22 . & obtain a BS/BA & 234 & 2.50 & 1.00 & $1-4$ \\
\hline 23. & $\begin{array}{l}\text { transfer to a } 4 \text {-year } \\
\text { college or university }\end{array}$ & 235 & 2.49 & .94 & $1-4$ \\
\hline
\end{tabular}

(Scale: 1=not important; $2=$ mildly important; 3 =moderately important; $4=$ very important)

Research Question 2

Can the 23 student outcome goals be factored into a smaller number of underlying constructs or dimensions?

Hypothesis 2. The 23 outcome goal measures represent a smaller number of constructs.

Factor analysis was used to test this proposition. Factor analysis involves four steps. First a correlation matrix is computed for all variables, and from the correlations, the appropriateness of using factor analysis for the data can be determined. Second, a factor extraction is performed which determines the number of factors necessary to represent the data. Third, a rotation is performed which groups inter-related variables into factors. 
Fourth, scores can be calculated for each of the factors and subsequently used in other statistical analyses.

Factor analysis with varimax rotation was performed using the data from the 23 outcome goals, producing six factors. An examination of the set of variables that contributed most strongly to each of the factors revealed clearly identifiable conceptual associations within each set. The researcher named each of the factors as follows:

- Factor 1 Personal/Social Development Outcomes

- Factor 2 Transfer Outcomes

- Factor 3 Credentialing outcomes

- Factor 4 Employment Outcomes

- Factor 5 Traditional College Learning outcomes

- Factor 6 Developmental Skills outcomes

Table 20 displays the results of the factor analysis including the variables contributing to each factor, the loading for the primary variables, the eigenvalue for each factor and the percentage of variance for each factor.

Once these factors were established, factor scores were saved from each of the six newly formed factors. These factor scores became the dependent variables in another series ANOVAs for which the biographical variables served as the independent variables. The independent variables were: (a) type of student stakeholder serves; (b) the stakeholders' professional role (instructor, support staff, or administrator); (c) number of years worked at a community 
college; (d) number of years worked at SCC; (e) the campus assignment of the stakeholder (Riverway Campus, The Extended Campus, Meadowland Campus, or Brooklyn Campus); and (f) gender. Results from these analyses are found in Appendix B and will be addressed briefly here.

Table 20

Factor Analysis of student outcome Variables

\begin{tabular}{|c|c|c|c|}
\hline Item & $\begin{array}{l}\text { Factor } \\
\text { Loading }\end{array}$ & $\begin{array}{l}\text { Eigen- } \\
\text { value }\end{array}$ & $\begin{array}{l}\text { Cumm } \\
\& \text { of } \\
\text { Var }\end{array}$ \\
\hline $\begin{array}{l}\text { FACTOR } 1 \\
\text { Personal/Social Dev outcomes }\end{array}$ & & 4.78 & 20.8 \\
\hline $\begin{array}{l}\text { (9) dev bias free values } \\
(14) \text { understand global interrel } \\
(8) \text { dev appreciation for learning } \\
(2) \text { dev positive behaviors } \\
\text { (3) acquire skills to learn } \\
\text { (1) dev positive self-perceptions }\end{array}$ & $\begin{array}{l}.77051 \\
.74848 \\
.72068 \\
.69249 \\
.54404 \\
.48783\end{array}$ & & \\
\hline $\begin{array}{l}\text { FACTOR } 2 \\
\text { Transfer outcomes }\end{array}$ & & 2.74 & 32.7 \\
\hline $\begin{array}{l}\text { (23) transfer } \\
(22) \text { obtain BA/BS } \\
\text { (16) transfer \& compete w/natives }\end{array}$ & $\begin{array}{r}.90624 \\
.90422 \\
.84558\end{array}$ & & \\
\hline $\begin{array}{l}\text { FACTOR } 3 \\
\text { Credentialing outcomes }\end{array}$ & & 2.67 & 44.2 \\
\hline $\begin{array}{l}\text { (20) obtain AA/AS } \\
(21) \text { obtain 1- or 2-yr certificate } \\
(18) \text { obtain prof cert/license } \\
\text { (19) obtain high school diploma/GED }\end{array}$ & $\begin{array}{l}.76388 \\
.75611 \\
.73736 \\
.68756\end{array}$ & & \\
\hline
\end{tabular}


Table 20

Factor Analysis of student Outcome Variables

(Continued)

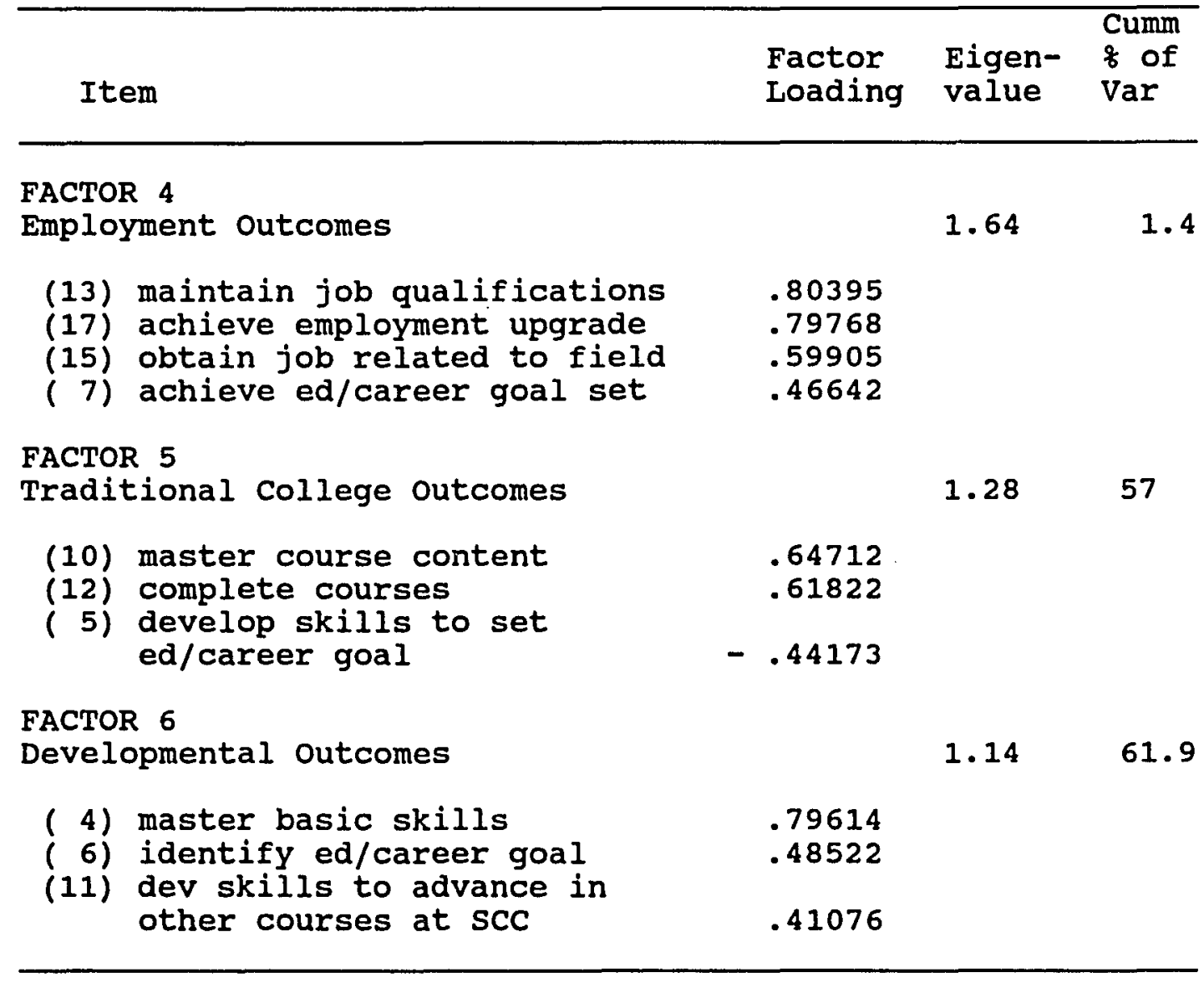

Significant differences were found for three of the independent variables. For the variable "number of years worked in a community college," a significant difference was found among the subgroups on (Factor 3) credentialing outcomes. For "gender," a significant difference was found for (Factor 1) Personal/Social Development. 
No differences were found among the means for the variables "professional role," "campus location," and "years at scc." For the variable "type of student served," significant differences were found among the subgroups on three factors: (Factor 2) Transfer Outcomes, (Factor 3) Credentialing Outcomes, and (Factor 4) Employment outcomes.

Research Question 3

Does the perceived importance of student outcomes vary in relationship to the type of student the stakeholder serves most often?

Hypothesis 3. There are no significant differences in the mean ratings on the 23 dependent variables (i.e., student outcome goals ratings) between stakeholders who served primarily: (a) professional/technical students (PT), (b) lower division transfer students (LDT), (c) developmental education students (DE), and (d) a combination of the three types of students (Combined).

This section presents the results concerning the relationship between type of student served and the perceived importance of the student outcomes. In order to test Hypothesis 3 , the dependent variables were analyzed using a univariate, one-way analysis of variance design with the alpha level set at .05. The SPSS subprogram ONEWAY Fratio and the scheffé multiple comparison procedure were performed to determine whether significant differences 
existed among the subgroups identified for study. Table 21 displays the results of the Analysis of Variance procedure. Using the type of student served as the independent variable and the outcome goals as the dependent variable, the hypothesis initially was confirmed for eight of the 23 variables. On the basis of the ANOVA, the hypothesis was rejected for the following 14 variables:

(Item 7) students achieve the educational or career goal(s) they have set for themselves at the college--with $\underline{f}(1)=2.6849, \underline{p}<.0473$;

(Item 8) students develop an intrinsic appreciation of learning--with $\mathrm{f}(1)=5.1145, \mathrm{p}<.0019$;

(Item 10) students master course content at a level set by the instructor--with $\underline{\mathrm{f}}(1)=7.4724, \mathrm{p}<.0001$;

(Item 11) students develop the skills and acquire the knowledge base to succeed in more advanced levels of courses at the college--with $\underline{f}(1)=2.9864, \underline{p}<$ $.0319 ;$

(Item 13) Students are able to maintain the qualifications for the jiob they now hold by upgrading their skills/knowledge--with $\underline{f}(1)=10.1791, \underline{p}<.0000$;

(Item 15) students obtain a job related to the curriculum they studied at SCC (regardless of program completion)--with $\underline{\underline{f}}(1)=17.2654, \mathrm{p}<.0000$; 
Table 21

Analysis of Variance for student outcome Goals Between Groups Based on Type of student Served

\begin{tabular}{|c|c|c|c|c|c|c|}
\hline Outcome Goal & $\begin{array}{l}\text { Source of } \\
\text { Variation }\end{array}$ & $\begin{array}{l}\text { Sum of } \\
\text { Squares }\end{array}$ & DF & $\begin{array}{l}\text { Mean } \\
\text { Squares }\end{array}$ & $\mathbf{F}$ & $\begin{array}{l}\text { F } \\
\text { Prob }\end{array}$ \\
\hline $\begin{array}{l}\text { 1. develop positive } \\
\text { self-perceptions }\end{array}$ & $\begin{array}{l}\text { Between grps } \\
\text { Within grps } \\
\text { Total }\end{array}$ & $\begin{array}{l}1.1823 \\
56.3135 \\
57.4958\end{array}$ & $\begin{array}{r}3 \\
234 \\
237\end{array}$ & $\begin{array}{l}.3941 \\
.2407\end{array}$ & 1.6376 & .1814 \\
\hline $\begin{array}{l}\text { 2. develop positive } \\
\text { behaviors }\end{array}$ & $\begin{array}{l}\text { Between grps } \\
\text { Within grps } \\
\text { Total }\end{array}$ & $\begin{array}{r}1.6166 \\
68.8185 \\
70.4351\end{array}$ & $\begin{array}{r}3 \\
235 \\
238\end{array}$ & $\begin{array}{l}.5389 \\
.2928\end{array}$ & 1.8401 & .1406 \\
\hline $\begin{array}{l}\text { 3. acquire a foundation of } \\
\text { knowledge/skills that } \\
\text { helps them adapt to } \\
\text { new learning demands }\end{array}$ & $\begin{array}{l}\text { Between grps } \\
\text { Within grps } \\
\text { Total }\end{array}$ & $\begin{array}{r}1.5674 \\
61.2225 \\
62.7899\end{array}$ & $\begin{array}{r}3 \\
234 \\
237\end{array}$ & $\begin{array}{l}.5225 \\
.2616\end{array}$ & 1.9970 & .1152 \\
\hline $\begin{array}{l}\text { 4. master a basic level } \\
\text { of skills in } \\
\text { reading, writing, math, } \\
\text { and language proficiency }\end{array}$ & $\begin{array}{l}\text { Between grps } \\
\text { Within grps } \\
\text { Total }\end{array}$ & $\begin{array}{l}.7224 \\
98.0549 \\
98.7773\end{array}$ & $\begin{array}{r}3 \\
234 \\
237\end{array}$ & $\begin{array}{l}.2408 \\
.4190\end{array}$ & .5747 & .6322 \\
\hline $\begin{array}{l}\text { 5. develop the skills to set } \\
\text { educational/career goals } \\
\text { for themselves }\end{array}$ & $\begin{array}{l}\text { Between grps } \\
\text { Within grps } \\
\text { Total }\end{array}$ & $\begin{array}{r}.2671 \\
101.4662 \\
101.7333\end{array}$ & $\begin{array}{r}3 \\
236 \\
239\end{array}$ & $\begin{array}{l}.0890 \\
.4299\end{array}$ & .2071 & .8914 \\
\hline
\end{tabular}


Table 21

Analysis of Variance for student outcome Goals Between Groups Based on Type of Student Served

(Continued)

\begin{tabular}{|c|c|c|c|c|c|c|}
\hline Outcome Goal & $\begin{array}{l}\text { Source of } \\
\text { Variation }\end{array}$ & $\begin{array}{l}\text { Sum of } \\
\text { Squares }\end{array}$ & $\mathrm{DF}$ & $\begin{array}{l}\text { Mean } \\
\text { Squares }\end{array}$ & $\mathbf{F}$ & $\begin{array}{l}\text { F } \\
\text { Prob }\end{array}$ \\
\hline $\begin{array}{l}\text { 6. identify ed./career } \\
\text { goals relevant to their } \\
\text { talents and abilities }\end{array}$ & $\begin{array}{l}\text { Between grps } \\
\text { within grps } \\
\text { Total }\end{array}$ & $\begin{array}{r}3.2743 \\
103.9642 \\
107.2385\end{array}$ & $\begin{array}{r}3 \\
235 \\
238\end{array}$ & $\begin{array}{r}1.0914 \\
.4424\end{array}$ & 2.4670 & .0629 \\
\hline $\begin{array}{l}\text { 7. achieve ed/career goals } \\
\text { they set for themselves }\end{array}$ & $\begin{array}{l}\text { Between grps } \\
\text { Within grps } \\
\text { Total }\end{array}$ & $\begin{array}{r}3.2942 \\
96.9298 \\
100.2241\end{array}$ & $\begin{array}{r}3 \\
237 \\
240\end{array}$ & $\begin{array}{r}1.0981 \\
.4090\end{array}$ & 2.6849 & .0473 \\
\hline $\begin{array}{l}\text { 8. develop an intrinsic } \\
\text { appreciation of } \\
\text { learning }\end{array}$ & $\begin{array}{l}\text { Between grp } \\
\text { Within grps } \\
\text { Total }\end{array}$ & $\begin{array}{r}6.9563 \\
105.6344 \\
112.5907\end{array}$ & $\begin{array}{r}3 \\
233 \\
236\end{array}$ & $\begin{array}{r}2.3188 \\
.4534\end{array}$ & 5.1145 & .0019 \\
\hline $\begin{array}{l}\text { 9. develop values free } \\
\text { of ethnic, cultural, } \\
\text { and gender bias }\end{array}$ & $\begin{array}{l}\text { Between grps } \\
\text { Within grps } \\
\text { Total }\end{array}$ & $\begin{array}{r}1 . \overline{4} \overline{168} \\
150.9349 \\
152.3517\end{array}$ & $\begin{array}{r}3 \\
232 \\
235\end{array}$ & $\begin{array}{l}.4723 \\
.6506\end{array}$ & .7259 & .5374 \\
\hline $\begin{array}{l}\text { 10. master course content } \\
\text { at a level set by } \\
\text { the instructor (s) }\end{array}$ & $\begin{array}{l}\text { Between grps } \\
\text { Within grps } \\
\text { Total }\end{array}$ & $\begin{array}{r}7.3408 \\
76.6256 \\
83.9664\end{array}$ & $\begin{array}{r}3 \\
234 \\
237\end{array}$ & $\begin{array}{r}2.4469 \\
.3275\end{array}$ & 7.4724 & .0001 \\
\hline $\begin{array}{l}\text { 11. develop the skills and } \\
\text { acquire the knowledge } \\
\text { base to succeed in more } \\
\text { advanced courses at SCC }\end{array}$ & $\begin{array}{l}\text { Between grps } \\
\text { Within grps } \\
\text { Total }\end{array}$ & $\begin{array}{r}5.4129 \\
141.3771 \\
146.7899\end{array}$ & $\begin{array}{r}3 \\
234 \\
237\end{array}$ & $\begin{array}{r}1.8043 \\
.6042\end{array}$ & 2.9864 & .0319 \\
\hline
\end{tabular}


Table 21

Analysis of Variance for student Outcome Goals Between

Groups Based on Type of student served

(Continued)

\begin{tabular}{|c|c|c|c|c|c|c|}
\hline Outcome Goal & $\begin{array}{l}\text { Source of } \\
\text { Variation }\end{array}$ & $\begin{array}{l}\text { Sum of } \\
\text { Squares }\end{array}$ & DF & $\begin{array}{l}\text { Mean } \\
\text { Squares }\end{array}$ & $\mathbf{F}$ & $\begin{array}{l}\text { F } \\
\text { Prob }\end{array}$ \\
\hline $\begin{array}{l}\text { 12. complete the scc courses } \\
\text { for which they enroll }\end{array}$ & $\begin{array}{l}\text { Between grps } \\
\text { Within grps } \\
\text { Total }\end{array}$ & $\begin{array}{r}1.8374 \\
135.7023 \\
137.5397\end{array}$ & $\begin{array}{r}3 \\
235 \\
238\end{array}$ & $\begin{array}{l}.6425 \\
.5775\end{array}$ & 1.0606 & .3665 \\
\hline $\begin{array}{l}\text { 13. maintain qualifications } \\
\text { for current job by } \\
\text { upgrading skills/knowl }\end{array}$ & $\begin{array}{l}\text { Between grps } \\
\text { Within grps } \\
\text { Total }\end{array}$ & $\begin{array}{r}22.0663 \\
170.5337 \\
192.6000\end{array}$ & $\begin{array}{r}3 \\
236 \\
239\end{array}$ & $\begin{array}{r}7.3554 \\
.7226\end{array}$ & 10.1791 & .0000 \\
\hline $\begin{array}{l}\text { 14. understand the } \\
\text { inter-relatedness of } \\
\text { our global society }\end{array}$ & $\begin{array}{l}\text { Between grps } \\
\text { Within grps } \\
\text { Total }\end{array}$ & $\begin{array}{r}5.9491 \\
195.7820 \\
201.7311\end{array}$ & $\begin{array}{r}3 \\
234 \\
237\end{array}$ & $\begin{array}{r}1.9830 \\
.8367\end{array}$ & 2.3701 & .0713 \\
\hline $\begin{array}{l}\text { 15. obtain a job related } \\
\text { to the curriculum } \\
\text { studied at SCC }\end{array}$ & $\begin{array}{l}\text { Between grps } \\
\text { Within grps } \\
\text { Total }\end{array}$ & $\begin{array}{r}30.7390 \\
140.0569 \\
170.7958\end{array}$ & $\begin{array}{r}3 \\
236 \\
239\end{array}$ & $\begin{array}{r}10.2463 \\
.5935\end{array}$ & 17.2654 & .0000 \\
\hline $\begin{array}{l}\text { 16. transfer to a } 4 \text {-year } \\
\text { college or university } \\
\text { and are academically } \\
\text { competitive with natives }\end{array}$ & $\begin{array}{l}\text { Between grps } \\
\text { Within grps } \\
\text { Total }\end{array}$ & $\begin{array}{r}73.9843 \\
207.1708 \\
281.1552\end{array}$ & $\begin{array}{r}3 \\
228 \\
231\end{array}$ & $\begin{array}{r}24.6614 \\
.9086\end{array}$ & 27.1409 & .0000 \\
\hline $\begin{array}{l}\text { 17. achieve employment } \\
\text { upgrade in their } \\
\text { current field of work }\end{array}$ & $\begin{array}{l}\text { Between grps } \\
\text { Within grps } \\
\text { Total }\end{array}$ & $\begin{array}{r}19.6905 \\
164.6429 \\
184.3333\end{array}$ & $\begin{array}{r}3 \\
236\end{array}$ & $\begin{array}{r}6.5635 \\
.6976\end{array}$ & 9.4081 & .0000 \\
\hline
\end{tabular}


Table 21

Analysis of Variance for student Outcome Goals Between

Groups Based on Type of Student Served

(Continued)

\begin{tabular}{|c|c|c|c|c|c|c|}
\hline Outcome Goal & $\begin{array}{l}\text { Source of } \\
\text { Variation }\end{array}$ & $\begin{array}{l}\text { Sum of } \\
\text { Squares }\end{array}$ & DF & $\begin{array}{l}\text { Mean } \\
\text { Squares }\end{array}$ & $\mathbf{F}$ & $\begin{array}{l}\text { F } \\
\text { Prob }\end{array}$ \\
\hline $\begin{array}{l}\text { 18. obtain certification } \\
\text { or licensure in their } \\
\text { profession }\end{array}$ & $\begin{array}{l}\text { Between grps } \\
\text { within grps } \\
\text { Total }\end{array}$ & $\begin{array}{r}34.4097 \\
197.0267 \\
231.4364\end{array}$ & $\begin{array}{r}3 \\
232 \\
235\end{array}$ & $\begin{array}{r}11.4699 \\
.8493\end{array}$ & 13.5059 & .0000 \\
\hline $\begin{array}{l}\text { 19. obtain a high school } \\
\text { diploma or GED }\end{array}$ & $\begin{array}{l}\text { Between grps } \\
\text { Within grps } \\
\text { Total }\end{array}$ & $\begin{array}{r}10.4194 \\
244.2315 \\
254.6509\end{array}$ & $\begin{array}{r}3 \\
228 \\
231\end{array}$ & $\begin{array}{l}3.4731 \\
1.0712\end{array}$ & 3.2423 & .0228 \\
\hline $\begin{array}{l}\text { 20. obtain an AS/AA or a } \\
1 \text { - or 2-year cert }\end{array}$ & $\begin{array}{l}\text { Between grps } \\
\text { Within grps } \\
\text { Total }\end{array}$ & $\begin{array}{r}11.9157 \\
173.3174 \\
185.2331\end{array}$ & $\begin{array}{r}3 \\
232 \\
235\end{array}$ & $\begin{array}{r}3.9719 \\
.7471\end{array}$ & 5.3167 & .0015 \\
\hline $\begin{array}{l}\text { 21. obtain an scc } \\
\text { certificate }\end{array}$ & $\begin{array}{l}\text { Between grps } \\
\text { Within grps } \\
\text { Total }\end{array}$ & $\begin{array}{r}18.5545 \\
176.5571 \\
195.1319\end{array}$ & $\begin{array}{r}3 \\
231 \\
234\end{array}$ & $\begin{array}{r}6.1849 \\
.7644\end{array}$ & 8.0912 & .0000 \\
\hline 22. obtain a BS/BA & $\begin{array}{l}\text { Between grps } \\
\text { within grps } \\
\text { Total }\end{array}$ & $\begin{array}{r}49.1290 \\
183.3667 \\
232.4957\end{array}$ & $\begin{array}{r}3 \\
230 \\
233\end{array}$ & $\begin{array}{r}16.3763 \\
.7972\end{array}$ & 20.5411 & .0000 \\
\hline $\begin{array}{l}\text { 23. transfer to a } 4 \text {-year } \\
\text { college or university }\end{array}$ & $\begin{array}{l}\text { Between grps } \\
\text { Within grps } \\
\text { Total }\end{array}$ & $\begin{array}{r}39.0613 \\
65.6792 \\
204.7404\end{array}$ & $\begin{array}{r}3 \\
231 \\
234\end{array}$ & $\begin{array}{r}13.0204 \\
.7172\end{array}$ & 18.1539 & .0000 \\
\hline
\end{tabular}


(Item 16) students transfer to a four-year college or university and are academically competitive with students who were lower division students at that institution--with $\underline{f}(1)=27.1409, \mathrm{p}<.0000$;

(Item 17) Students achieve an employment upgrade in their current field of work--with $\underline{f}(1)=9.4081, \underline{p}<$ .0000

(Item 18) Students obtain an associate degree--with $\underline{f}(1)=$ $13.5059, \mathrm{p}<.0000$;

(Item 19) students obtain a high school diploma or GED--with $\underline{f}(1)=3.2423, \underline{p}<.0228 ;$

(Item 20) students obtain an associate degree--with $\underline{f}(1)=$ $5.3167, \underline{p}<.0015 ;$

(Item 21) students obtain a 1 - or 2-year certificate from the college--with $\underline{f}(1)=8.0912, \mathrm{p}<.0000$;

(Item 22) students obtain a baccalaureate degree or higher-with $\underline{f}(1)=20.5411, \underline{p}<.0000$;

(Item 23) students transfer to a four-year college or university--with $\underline{\underline{f}}(1)=18.1539, \underline{p}<.0000$.

In the secondary analysis, the scheffe multiple comparison procedure was used to identify the subgroups between which significant differences existed. As discussed in the statistical Design section of Chapter III, employing the scheffe increases confidence in the rejection of the null hypothesis when the test identifies between which group means significant differences exist. 
As noted above, the scheffé test, used on all of the items for which the ANOVA revealed differences in the means among the four groups (PT, DE, LDT, and Combined), identified significant differences between subgroup means for 14 dependent variables. Table 22 lists these items, shows the mean for each subgroup, and indicates between which groups statistically significant differences were found.

Table 22

Scheffé Multiple Range Test of Differences Between Means for the Independent Variable Type of student Served

Item 8: develop intrinsic appreciation of learning

Mean Group

3.3765 Prof/Tech

3.2778 DE

3.7593 LDT

3.3500 Combined

Item 10: master course content set by teacher

3.5714 Prof/Tech

3.2222 DE

3.4444 LDT

3.1707 Combined 
Table 22

Scheffé Multiple Range Test of Differences Between

Means for the Independent Variable

Type of student served

(Continued)

\begin{tabular}{|c|c|c|c|c|c|}
\hline & & \multicolumn{2}{|c|}{ Type of student } & LDT & Combined \\
\hline \multicolumn{6}{|c|}{$\begin{array}{l}\text { Item 13: maintain } \\
\text { job qualifications }\end{array}$} \\
\hline Mean & Group & & & & \\
\hline $\begin{array}{l}3.3529 \\
3.2222 \\
2.5849 \\
3.2857\end{array}$ & $\begin{array}{l}\text { Prof/Tech } \\
\text { DE } \\
\text { LDT } \\
\text { Combined }\end{array}$ & $\star * *$ & & & $\star \star \star$ \\
\hline \multicolumn{6}{|c|}{$\begin{array}{l}\text { Item 15: obtain job } \\
\text { related to curriculum }\end{array}$} \\
\hline $\begin{array}{l}3.4286 \\
2.7778 \\
2.4815 \\
3.0357\end{array}$ & $\begin{array}{l}\text { Prof / Tech } \\
\text { DE } \\
\text { LDT } \\
\text { Combined }\end{array}$ & $\begin{array}{l}\star \star \star \\
\star \star \star \\
\star \star *\end{array}$ & & & $\star \star *$ \\
\hline \multicolumn{6}{|c|}{$\begin{array}{l}\text { Item 16: transfer and } \\
\text { compete with natives }\end{array}$} \\
\hline $\begin{array}{l}2.2875 \\
2.3333 \\
3.6111 \\
3.2750\end{array}$ & $\begin{array}{l}\text { Prof/Tech } \\
\text { DE } \\
\text { LDT } \\
\text { Combined }\end{array}$ & $\begin{array}{l}\star \star \star * \\
\star * \star\end{array}$ & $\star \star *$ & & $\star \star \star$ \\
\hline \multicolumn{6}{|c|}{$\begin{array}{l}\text { Item 17: achieve } \\
\text { employment upgrade }\end{array}$} \\
\hline $\begin{array}{l}3.0357 \\
3.1667 \\
2.3889 \\
3.0833\end{array}$ & $\begin{array}{l}\text { Prof / Tech } \\
\text { DE } \\
\text { LDT } \\
\text { Combined }\end{array}$ & $\star \star \star$ & $\star \star \star$ & & $\star \star \star$ \\
\hline
\end{tabular}


Table 22

Scheffé Multiple Range Test of Differences Between

Means for the Independent Vaxiable

Type of student Served

(Continued)

Type of student

Prof/Tech DE IDT Combined

Item 18: get license

or prof certification

3.2651 Prof/Tech

2.8889 DE

2.2407 LDT

2.9012 Combined

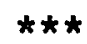

***

Item 19: obtain high

school diploma/GED

$\begin{array}{ll}2.9750 & \text { Prof/Tech } \\ 2.8333 & \text { DE } \\ 2.4151 & \text { LDT } \\ 2.8395 & \text { Combined }\end{array}$

Item 20: obtain

associate degree

2.9643 Prof/Tech

2.5000 DE

2.4074 LDT

2.8375 Combined

Item 21: obtain

college certificate

2.8171 Prof/Tech

2.5000 DE

2.0926 LDT

2.6914 Combined

$\star * *$

Item 22: obtain

BA/BS

1.9549 Prof/Tech

2.1111 DE

3.1111 IDT

2.7089 Combined

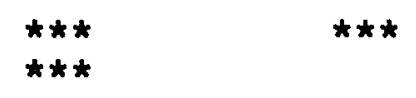


Table 22

Scheffé Multiple Range Test of Differences Between Means for the Independent Variable Type of student Served

(Continued)

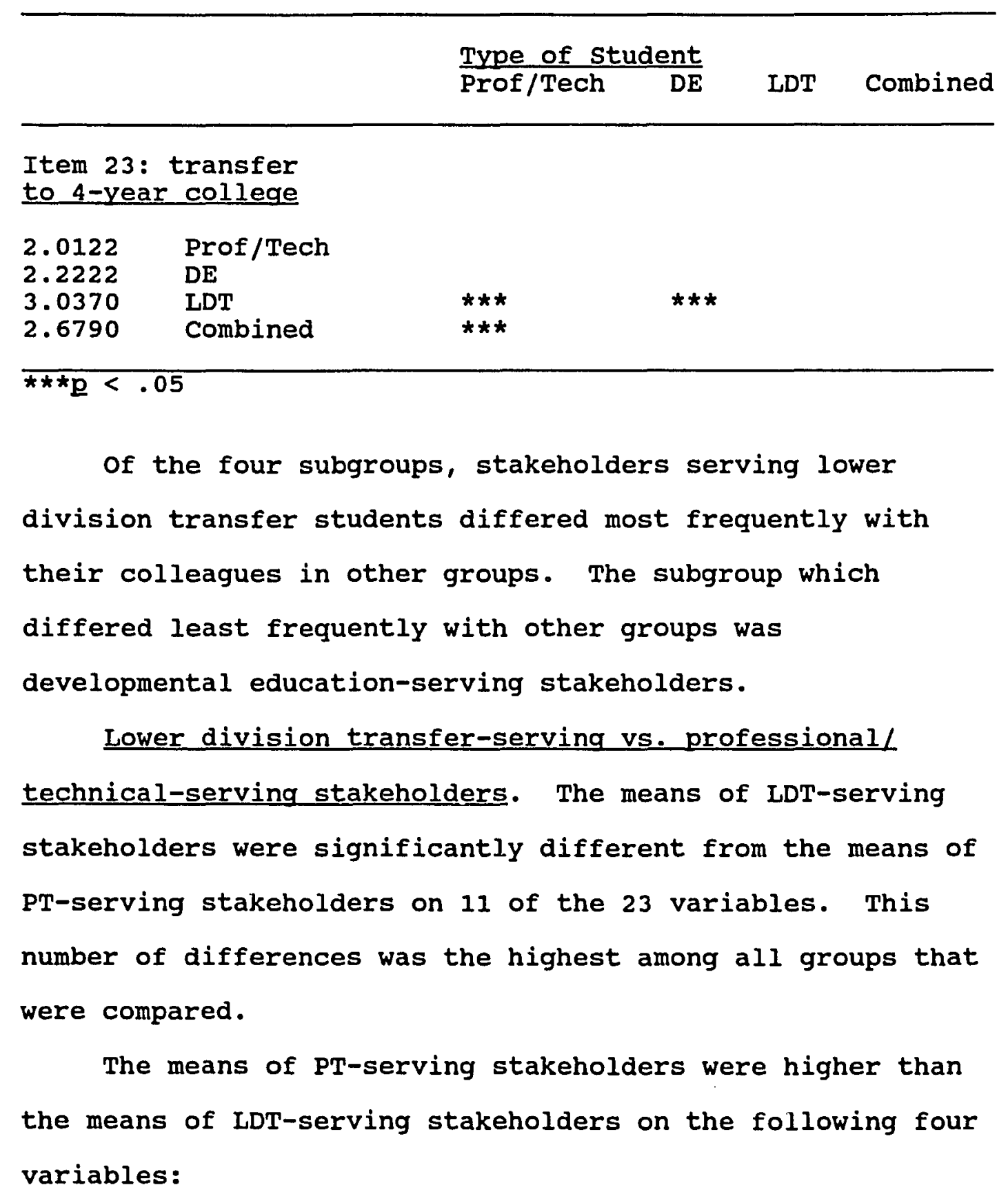


(Item 8) Students develop an appreciation of learning--with an LDT mean of 3.7593 and a PT mean of 3.3765 ;

(Item 16) students transfer and compete with natives--with an LDT mean of 3.6111 and a PT mean of 2.2875 ;

(Item 22) Students obtain a BA/BS--with an LDT mean of 3.111 and a PT mean of 1.9549 ; and

(Item 23) Students transfer--with an LDT mean of 3.0370 and a PT mean of 2.0122 .

The outcomes above, rated higher by LDT-serving stakeholders, were associated with transferring and earning a baccalaureate degree with the exception of the outcome "students develop an intrinsic appreciation for learning." The means of LDT-serving stakeholders were lower than the means of the PT-serving stakeholders on the following seven variables:

(Item 13) students maintain job qualifications--with an LDT mean of 2.5849 and a PT mean of 3.3529 ;

(Item 15) students obtain a job related to curriculum--with an LDT mean of 2.4815 and a PT mean of 3.4286 ;

(Item 17) Students achieve an employment upgrade--with an LDT mean of 2.3889 and a PT mean of 3.0357 ;

(Item 18) students get professional licensure--with an LDT mean of 2.2407 and a PT mean of 3.2651;

(Item 19) Students obtain a high school diploma or GED--with an LDT mean of 2.4151 and a PT mean of 2.9750; 
(Item 20) students obtain an associate degree--with an LDT mean of 2.4074 and a PT mean of 2.9643 ; and,

(Item 21) students obtain an SCC certificate--with an LDT mean of 2.0926 and a PT mean of 2.8171 .

These outcomes, rated lower by LDT-serving stakeholders than PT-serving stakeholders, were associated with either employment or earning specific education credentials. Lower division transfer-serving vs. combined-serving stakeholders. Stakeholders serving lower division transfer course students differed second most frequently with their colleagues who served a combination of student groups. The means for this group were significantly different on eight of the 23 dependent variables.

The means of LDT-serving stakeholders were higher than stakeholders serving a combination of students on the following two variables:

(Item 1) Students develop an appreciation for learning-with an LDT mean of 3.7593 and a Combined mean of $3.3500 ;$ and

(Item 16) students transfer and compete--with an LDT mean of 3.6111 and a Combined mean of 3.2750 .

The means of LDT-serving stakeholders were lower than stakeholders serving a combination of students on the following six variables:

(Item 13) students maintain job qualifications--with an LDT mean of 2.5849 and a Combined mean of 3.2857 ; 
(Item 15) Students obtain jobs related to the curriculum-with an LDT mean of 2.4815 and a Combined mean of 3.0357;

(Item 17) Students achieve employment upgrade with an LDT mean of 2.3889 and a Combined mean of 3.0833 ;

(Item 18) Students obtain professional licensure or certification with an LDT mean of 2.2407 and a Combined mean of 2.9012;

(Item 20) Student obtain an associate degree with an LDT mean of 2.4074 and a Combined mean of 2.8375 ; and

(Item 21) Students obtain an SCC college certificate with an LDT mean of 2.0926 and a Combined mean of 2.6914 . These outcomes, which were rated lower by LDT-serving stakeholders, were associated with employment or earning specific credentials. It should be noted that this pattern parallels the difference between lower division transferserving stakeholders and professional/technical-serving stakeholders described above.

Professional/technical-serving vs. combined-serving. The researcher found that the groups with the third most frequent number of significant differences between means were stakeholders serving professional/technical students and those serving a combined group of students. These groups differed on five of the variables. 
The means of PT-serving stakeholders were higher than their colleagues serving combined stakeholders on the following two variables:

(Item 10) Students master course content set by teacher-with a PT mean of 3.5714 and a combined mean of 3.1707 ; and

(Item 15) Students obtain a job--with a PT mean of 3.4286 and a combined mean of 3.0357 .

The means of PT-serving stakeholders were lower than their colleagues serving combined stakeholders on the following three variables, all of which are related to transfer:

(Item 16) students transfer and compete--with a PT mean of 2.2875 and a Combined mean of 3.2750 ;

(Item 22) Students obtain a BA/BS--with a PT mean of 1.9549 and a Combined mean of 2.7089 ; and

(Item 23) Students transfer--with a PT mean of 2.0122 and a Combined mean of 2.6790 .

Lower division transfer-serving $v$. Developmental education-serving. The groups with the fourth most frequent number of significant differences were stakeholders serving lower division transfer students and those serving developmental education students. The means of these two groups differed significantly on three of the dependent variables. The mean for lower division transfer-serving 
stakeholders was higher on only two variables, both related to transfer:

(Item 22) students obtain a BA/BS--with an LDT mean of 3.111 and a DE mean of $2.111 ;$ and

(Item 23) Students transfer--with an LDT mean of 3.0370 and a DE mean of 2.222 .

The mean for lower division transfer-serving stakeholders was lower on only one variable: (Item 17) students achieve an employment upgrade--with an ILDT mean of 2.3889 and a DE mean of 3.1667 . Professional/technical-serving vs. developmental education-serving. There were significant differences among the means of stakeholders serving professional technical students and those serving developmental education students on only one variable:

(Item 16) students transfer and compete--with PT mean of 3.6111 and Combined mean of 3.2750 . Developmental education-serving vs. combined-serving. Finally, the researcher found significant differences among the means of stakeholders serving developmental education students and those serving combined students on only one variable:

(Item 16) students transfer and compete with natives--with a DE mean of 2.3333 and a Combined mean of 3.2750 . 
Research Question 4

Is it possible to predict which outcomes are valued most highly by stakeholders based on the type of students they serve?

Hypothesis 4. There are no significant sets of predictor variables (i.e., student outcome goals) that accurately predict the criterion variable (i.e., type of student served).

This research question and its related hypothesis were formulated in order to delve more systematically into the differences among the four subgroups which were based on the type of students served. In order to test Hypothesis 4 , the statistical test linear discriminant function analysis was performed. The purpose of this test was to determine whether a set of common predictor variables (i.e., the 23 student outcome goals) could predict with a high percentage of accuracy the subgroups that comprise the criterion variable "type of student served." The sPSS subprogram DISCRIMINANT was performed to derive this statistic. In this analysis, the predictor or independent variables were the 23 outcomes measures. The criterion or dependent variable was "type of student served." The categories for this variable are: (a) professional/technical students, (b) developmental education students, (c) lower division transfer students, and (d) combined students. 
The first stage of discriminant analysis creates a small number of discriminant functions between groups using the independent variable. A standardized weighting coefficient is calculated which indicates the relative importance of each variable toleach discriminant:function.

The second stage of the analysis involves classifying individual cases into the criterion groups and determining the accuracy of these predictions. To do this, a discriminant score is calculated for each case by multiplying the coefficients by the respective variable values for each individual case. Using the discriminant score, individual cases are classified into the criterion group that their discriminant score most closely: approximates. The degree of accuracy is stated as the percentage of correctly predicted classifications. This final comparison between the predicted classification and actual classification can be done because the actual group affiliation (i.e., to which group each case belongs) is already known.

Discriminant function results. As displayed in Table 23, the first stage of the discriminant analysis produced three functions and calculated Istandardized discriminant function coefficients using 20 of the 23 variables. The variables in the table have been ordered by size lof coefficient within each function. A stepwise variable selection method resulted in three variables being dropped 
from the analysis because they did not offer unique information from the other 20 variables. These variables were: Students master basic skills; students obtain high school diplomas/GEDs; students obtain SCC certificate.

Table 23

Standardized Discriminant Function Coefficients

\begin{tabular}{|c|c|c|c|c|}
\hline & & \multicolumn{3}{|c|}{ Standardized Value } \\
\hline \multicolumn{2}{|c|}{ Variable } & Function 1 & Function 2 & Function 3 \\
\hline 16. & Transfers/competes & .69332 & & \\
\hline 22 . & Obtains BA/BS & .58906 & & \\
\hline 18 & $\begin{array}{l}\text { Obtains professional } \\
\text { certification }\end{array}$ & .46819 & & \\
\hline 6 & $\begin{array}{l}\text { Identifies } \\
\text { career/ed goal }\end{array}$ & & .73523 & \\
\hline 23. & Transfers & & -.70328 & \\
\hline 20 & Obtains AA/AS & & .53837 & \\
\hline 17 . & Obtains empl upgrade & & -.45445 & \\
\hline 13. & Maintains job qualif & & .37239 & \\
\hline 2 & $\begin{array}{l}\text { Develops } \\
\text { positive behaviors }\end{array}$ & & .37132 & \\
\hline 11. & $\begin{array}{l}\text { Learns skills to } \\
\text { advance in classes }\end{array}$ & & -.35354 & \\
\hline 15 . & Obtain job in field & & .35328 & \\
\hline 14. & $\begin{array}{l}\text { Understand } \\
\text { interrelatedness } \\
\text { of global society }\end{array}$ & & .33577 & \\
\hline 10. & Master course content & & & .71441 \\
\hline
\end{tabular}


Table 23

Standardized Discriminant Function Coefficients

(Continued)

\begin{tabular}{|c|c|c|c|c|}
\hline \multirow{2}{*}{\multicolumn{2}{|c|}{ Variable }} & \multicolumn{3}{|c|}{ Standardized Value } \\
\hline & & \multirow[t]{2}{*}{ Function 1} & \multirow[t]{2}{*}{ Function 2} & \multirow{2}{*}{$\begin{array}{l}\text { Function } 3 \\
-.43520\end{array}$} \\
\hline 7. & $\begin{array}{l}\text { Achieve ed/ } \\
\text { career goal }\end{array}$ & & & \\
\hline 1. & $\begin{array}{l}\text { Develop positive } \\
\text { behaviors }\end{array}$ & & & -.39570 \\
\hline 8. & Appreciate learning & i & & .37357 \\
\hline 5. & $\begin{array}{l}\text { Learn skills to } \\
\text { set goals }\end{array}$ & & & .32153 \\
\hline 3. & $\begin{array}{l}\text { Acquire } \\
\text { learning skills }\end{array}$ & & & -.31843 \\
\hline 12 . & $\begin{array}{l}\text { Complete } \\
\text { scc courses }\end{array}$ & & & .31343 \\
\hline 9. & $\begin{array}{l}\text { Develop } \\
\text { bias free values }\end{array}$ & & & .26971 \\
\hline
\end{tabular}

Function 1 contained only three variables: (Item 16) Students transfer and compete; (Item 22) Students obtain a BA/BS; and (Item 18) students obtain professional certification.

Function 2 was made up of nine variables. The researcher could find no distinct pattern among these variables, although she noted that none of the variables in the factor analysis that made up the factor Traditional college outcomes were included. 
Function 3 was made up of eight variables. Again, no discernable pattern was found, although none of the variables that made up the factors Transfer outcomes or Credentialing outcomes were included.

In discriminant analysis, the first function always has the most between-groups variability, the second function the next most, the third function the next most, etc. As expected, the findings in Table 24 above indicate that Function 1 is the strongest function and that Functions 2 and 3 contribute less to the discriminate function.

To evaluate the effectiveness of the discriminant function, one examines the percentage of cases classified correctly. However, another indicator of effectiveness is the amount of between-groups variability of a given function. In order to ascertain the percentage of the total between-groups variability attributable to each function, the eigenvalue (i.e., the ratio of between-groups to withingroups sums of squares) is examined. Norusis (SPSS, 1992) states, "Large eigenvalues are associated with 'good' functions" (p. 17). For the current analysis, the eigenvalues and percentage of variance attributable to each of the three functions is displayed in Table 24. Function 1 accounted for $73.88 \%$ of the between-groups variability. Function 2 accounted for 16.81\%, and Function 3 accounted for $9.32 \%$ of between-groups variability. 
Table 24

Eigenvalues for the Discriminant Functions

\begin{tabular}{crc}
\hline Function & Eigenvalues & Percent of Variance \\
\hline 1 & 1.3933 & 73.88 \\
2 & .3169 & 16.81 \\
3 & .1757 & 9.32 \\
\hline
\end{tabular}

To test the significance of the three discriminant functions, a Wilks' lambda statistic was performed. The null hypothesis tested by this statistic is that the means of all discriminant functions in the four groups in the population are equal (i.e., no difference exists between the means of the four groups). For the three functions produced by the discriminant analysis, between group means were found to be statistically significant. Table 25 displays wilks' lambda, chi-square, degrees of freedom, probability level for significance of each function.

Table 25

Statistical Significance for the Discriminant Functions

\begin{tabular}{ccccc}
\hline Function & Wilks' Lambda & Chi-square & DF & Sign \\
& & & & \\
1 & .2699 & 261.965 & 60 & .0000 \\
2 & .6459 & 87.431 & 38 & .0000 \\
3 & .8506 & 32.370 & 18 & .0199 \\
\hline
\end{tabular}


classification results. For the second stage of the discriminant analysis, discriminant scores were calculated for each case and used to predict group membership. Predicted group membership then was compared to the actual group membership. Table 26 displays the classifications showing the number and percentage of predicted group membership in each category. Correctly predicted group membership is read on the diagonal. The function classified $68.98 \%$ of cases correctly. It was most accurate in predicting the stakeholder group who served lower division transfer students with $80.8 \%$ accuracy. It succeeded in accurately predicting stakeholders who served professional/technical students and combined students at similar percentages of $66.2 \%$ and $66.7 \%$ respectively. It was least accurate in predicting stakeholders who served students in developmental education with 55.68 accuracy, only slightly better than would be expected by chance. The low predictive capacity for developmental-serving stakeholders may be a function of the small number cases in this category (only 18).

In summary, Hypothesis 4 , which states that, there are no significant sets of predictor variables (i.e., student outcome goals) that accurately predict the criterion variable (i.e., type of student served) was rejected by discriminant analysis. The analysis produced three functions that in combination were able to predict the 
student group served by the stakeholders in approximately 698 of all cases. The functions were most accurate in predicting stakeholders serving transfer students-approximately $81 \%--$ and least accurate predicting stakeholders serving developmental students--approximately 56\%. It should be noted that each of these percentages represents predictive ability that is better than the $50 \%$ than would be expected by chance. While the procedure built a successful classification model, the researcher was not able to use the results of the analysis to predict the student outcome goals that subjects in the four groups valued most highly. No pattern could be discerned in the variables contributing to the three functions and, consequently, there were no interpretable results.

Table 26

Classification Results: Number and Percentage of Predicted Cases Assigned to the Type of student Served Subgroups

\begin{tabular}{|c|c|c|c|c|c|c|c|c|c|}
\hline \multirow{3}{*}{$\begin{array}{l}\text { Actual } \\
\text { Group } \\
\text { Prof/tech }\end{array}$} & \multirow{3}{*}{$\begin{array}{c}\begin{array}{c}\text { No. } \\
\text { Cases }\end{array} \\
74\end{array}$} & \multicolumn{8}{|c|}{ Predicted Group Membership } \\
\hline & & \multicolumn{2}{|c|}{ Prof / Tech } & \multicolumn{2}{|c|}{ Dev Ed } & \multicolumn{2}{|c|}{ LDT } & \multicolumn{2}{|c|}{ Combined } \\
\hline & & 49 & 66.28 & 12 & 16.28 & 0 & $0 q$ & 13 & 17.68 \\
\hline Dev ed & 18 & 3 & $16.7 \%$ & 10 & $55.6 \%$ & 1 & 5.68 & 4 & 22.28 \\
\hline LDT & 52 & 1 & 1.98 & 2 & $3.8 \%$ & 42 & $80.8 \%$ & 7 & 13.58 \\
\hline Combined & 72 & 7 & 9.78 & 9 & 12.58 & 8 & 11.18 & 48 & 66.78 \\
\hline
\end{tabular}


Research Question 5 a

Does the perceived importance of student outcome goals vary in relationship to professional role?

Hypothesis 5a. There are no significant differences in the mean ratings on the 23 dependent variables (i.e., student outcome goals ratings) between stakeholders who performed the professional roles of teacher, instructional administrator, and support staff.

This section presents the results concerning the relationship between professional role of the instructional stakeholders and the perceived importance of the outcome goals. In order to test Hypotheses $5 \mathrm{a}$, each of the 23 dependent variables (i.e., the student outcome goals) were analyzed using a univariate, one-way analysis of variance design with the alpha level set at .05. The SPSS subprogram ONEWAY and the scheffé multiple comparison procedure were performed to determine whether significant differences existed among the subgroups.

Using the professional role as the independent variable and the outcome goals as the dependent variable, the one-way analysis of variance confirmed the statistical hypothesis that no significant difference existed between the means of the three groups for 17 of the 23 items. This initial analysis found six items for which a significant $F$ was produced, indicating that the populations' means were probably not all equal, and the null hypothesis should be 
rejected. Table 27 shows the results of the ANOVA for all of the dependent variables.

The six items for which the hypothesis was rejected were:

(Item 1) Students develop a positive self-perception of themselves-with $\underline{\mathrm{f}}(1)=3.9296, \underline{\mathrm{p}}<.0211$;

(Item 6) Students identify an educational or career goal relevant to their talents and abilities-- with $\underline{f}(1)=3.8372, \underline{p}<.0231$;

(Item 9) Students develop values free of ethnic, cultural, and gender bias--with $\underline{\underline{f}}(1)=4.5267, \underline{\mathrm{p}}<.0119$;

(Item 14) students understand the inter-relatedness of our global society--with $\underline{f}(1)=3.4853, \underline{p}<.0324$;

(Item 16) students transfer to a four-year college or university and are academically competitive with students who were lower division students at that institution--with $\underline{f}(1)=3.8621, \underline{p}<.0226$; and,

(Item 18) students obtain certification or licensure from their professional organizations" with $\underline{\mathrm{f}}(1)=$ $3.0918, \mathrm{p}<.0475$.

For this analysis in which the professional role of the stakeholder was used as the independent variable, the researcher was unable to identify a pattern in the type outcomes for which significant differences were found. 
Table 27

Analysis of Variance for Student Outcome Goals with Groups Based on the Professional Role

\begin{tabular}{|c|c|c|c|c|c|c|}
\hline Outcome Goal & $\begin{array}{l}\text { Source of } \\
\text { Variation }\end{array}$ & $\begin{array}{l}\text { Sum of } \\
\text { Squares }\end{array}$ & DF & $\begin{array}{l}\text { Mean } \\
\text { Squares }\end{array}$ & $\mathbf{F}$ & $\begin{array}{l}\text { F } \\
\text { Prob }\end{array}$ \\
\hline $\begin{array}{l}\text { 1. develop positive } \\
\text { self-perceptions }\end{array}$ & $\begin{array}{l}\text { Between grps } \\
\text { Within grps } \\
\text { Total }\end{array}$ & $\begin{array}{r}1.9186 \\
51.2645 \\
53.1831\end{array}$ & $\begin{array}{r}2 \\
210 \\
212\end{array}$ & $\begin{array}{r}.9593 \\
3.9296\end{array}$ & 3.9296 & .0211 \\
\hline $\begin{array}{l}\text { 2. develop positive } \\
\text { behaviors }\end{array}$ & $\begin{array}{l}\text { Between grps } \\
\text { Within grps } \\
\text { Total }\end{array}$ & $\begin{array}{l}. \overline{1} \overline{0} \overline{0} \\
61.3143 \\
61.4233\end{array}$ & $\begin{array}{r}2 \\
212 \\
214\end{array}$ & $\begin{array}{l}.0545 \\
.2892\end{array}$ & .1884 & .8284 \\
\hline $\begin{array}{l}\text { 3. acquire a foundation of } \\
\text { knowledge/skills that } \\
\text { helps them adapt to } \\
\text { new learning demands }\end{array}$ & $\begin{array}{l}\text { Between grps } \\
\text { Within grps } \\
\text { Total }\end{array}$ & $\begin{array}{l}.7250 \\
58.8871 \\
59.6121\end{array}$ & $\begin{array}{r}2 \\
211 \\
213\end{array}$ & $\begin{array}{l}.3625 \\
.2791\end{array}$ & 1.2989 & .2750 \\
\hline $\begin{array}{l}\text { 4. master a basic level } \\
\text { of skills in } \\
\text { reading, writing, math, } \\
\text { and language proficiency }\end{array}$ & $\begin{array}{l}\text { Between grps } \\
\text { Within grps } \\
\text { Total }\end{array}$ & $\begin{array}{r}2.4373 \\
89.6608 \\
92.0981\end{array}$ & $\begin{array}{r}2 \\
211 \\
213\end{array}$ & $\begin{array}{r}1.2187 \\
.4249\end{array}$ & 2.8679 & .0590 \\
\hline $\begin{array}{l}\text { 5. develop the skills to set } \\
\text { educational/career goals } \\
\text { for themselves }\end{array}$ & $\begin{array}{l}\text { Between grps } \\
\text { Within grps } \\
\text { Total }\end{array}$ & $\begin{array}{r}2.0425 \\
95.3529 \\
97.3953\end{array}$ & $\begin{array}{r}2 \\
212 \\
214\end{array}$ & $\begin{array}{r}1.0212 \\
.4498\end{array}$ & 2.2705 & .1058 \\
\hline $\begin{array}{l}\text { 6. identify ed./career } \\
\text { goals }\end{array}$ & $\begin{array}{l}\text { Between grps } \\
\text { Within grps } \\
\text { Total }\end{array}$ & $\begin{array}{r}3.6002 \\
98.9839 \\
102.5841\end{array}$ & $\begin{array}{r}2 \\
211 \\
213\end{array}$ & $\begin{array}{r}1.8001 \\
.4691\end{array}$ & 3.8372 & .0231 \\
\hline
\end{tabular}


Table 27

Analysis of Variance for student outcome Goals with Groups Based on the Professional Role (Continued)

\begin{tabular}{|c|c|c|c|c|c|c|}
\hline Outcome Goal & $\begin{array}{l}\text { Source of } \\
\text { Variation }\end{array}$ & $\begin{array}{l}\text { Sum of } \\
\text { Squares }\end{array}$ & $\mathrm{DF}$ & $\begin{array}{l}\text { Mean } \\
\text { Squares }\end{array}$ & $\mathbf{F}$ & $\begin{array}{l}\text { F } \\
\text { Prob }\end{array}$ \\
\hline $\begin{array}{l}\text { 7. achieve ed/career goals } \\
\text { they set for themselves }\end{array}$ & $\begin{array}{l}\text { Between grps } \\
\text { Within grps } \\
\text { Total }\end{array}$ & $\begin{array}{l}.4444 \\
93.3889 \\
93.8333\end{array}$ & $\begin{array}{r}2 \\
213 \\
215\end{array}$ & $\begin{array}{l}.2222 \\
.4384\end{array}$ & .5068 & .6031 \\
\hline $\begin{array}{l}\text { 8. develop an intrinsic } \\
\text { appreciation of } \\
\text { learning }\end{array}$ & $\begin{array}{l}\text { Between grps } \\
\text { Within grps } \\
\text { Total }\end{array}$ & $\begin{array}{r}.1319 \\
100.6005 \\
100.7324\end{array}$ & $\begin{array}{r}2 \\
210 \\
212\end{array}$ & $\begin{array}{l}.0659 \\
.4790\end{array}$ & .1377 & .8715 \\
\hline $\begin{array}{l}\text { 9. develop values free } \\
\text { of ethnic, cultural, } \\
\text { and gender bias }\end{array}$ & $\begin{array}{l}\text { Between grps } \\
\text { Within grps } \\
\text { Total }\end{array}$ & $\begin{array}{r}5.9606 \\
137.6007 \\
143.5613\end{array}$ & $\begin{array}{r}2 \\
209 \\
211\end{array}$ & $\begin{array}{r}2.9803 \\
.6584\end{array}$ & 4.526 & .0119 \\
\hline $\begin{array}{l}\text { 10. master course content } \\
\text { at a level set by } \\
\text { the instructor }(s)\end{array}$ & $\begin{array}{l}\text { Between grps } \\
\text { Within grps } \\
\text { Total }\end{array}$ & $\begin{array}{l}.8682 \\
74.1598 \\
75.0280\end{array}$ & $\begin{array}{r}2 \\
211 \\
213\end{array}$ & $\begin{array}{l}.4341 \\
.3515\end{array}$ & 1.2351 & .2929 \\
\hline $\begin{array}{l}\text { 11. develop the skills and } \\
\text { acquire the knowledge } \\
\text { base to succeed in more } \\
\text { advanced courses at sCC }\end{array}$ & $\begin{array}{l}\text { Between grps } \\
\text { Within grps } \\
\text { Total }\end{array}$ & $\begin{array}{r}1.0737 \\
130.5385 \\
131.6121\end{array}$ & $\begin{array}{r}2 \\
211 \\
213\end{array}$ & $\begin{array}{l}.5368 \\
.6187\end{array}$ & .8677 & .4214 \\
\hline $\begin{array}{l}\text { 12. complete the scc courses } \\
\text { for which they enroll }\end{array}$ & $\begin{array}{l}\text { Between grps } \\
\text { Within grps } \\
\text { Total }\end{array}$ & $\begin{array}{r}2.7393 \\
127.6205 \\
130.3598\end{array}$ & $\begin{array}{r}2 \\
211 \\
213\end{array}$ & $\begin{array}{r}1.3697 \\
.6048\end{array}$ & 2.2645 & .1064 \\
\hline
\end{tabular}


Table 27

Analysis of Variance for student Outcome Goals with Groups Based on the Professional Role

(Continued)

\begin{tabular}{|c|c|c|c|c|c|c|}
\hline Outcome Goal & $\begin{array}{l}\text { Source of } \\
\text { Variation }\end{array}$ & $\begin{array}{l}\text { Sum of } \\
\text { Squares }\end{array}$ & DF & $\begin{array}{l}\text { Mean } \\
\text { Squares }\end{array}$ & $\mathbf{F}$ & $\begin{array}{l}\text { F } \\
\text { Prob }\end{array}$ \\
\hline $\begin{array}{l}\text { 13. maintain qualifications } \\
\text { for current job by } \\
\text { upgrading skills/knowl }\end{array}$ & $\begin{array}{l}\text { Between grps } \\
\text { Within grps } \\
\text { Total }\end{array}$ & $\begin{array}{r}4.8600 \\
172.8888 \\
177.7488\end{array}$ & $\begin{array}{r}2 \\
212 \\
214\end{array}$ & $\begin{array}{r}2.4300 \\
.8155\end{array}$ & 2.9797 & .0529 \\
\hline $\begin{array}{l}\text { 14. understand the } \\
\text { inter-relatedness of } \\
\text { our global society }\end{array}$ & $\begin{array}{l}\text { Between grps } \\
\text { within grps } \\
\text { Total }\end{array}$ & $\begin{array}{r}5.7881 \\
175.2072 \\
180.9953\end{array}$ & $\begin{array}{r}2 \\
211\end{array}$ & $\begin{array}{r}2.8940 \\
.8304\end{array}$ & 3.4853 & .0324 \\
\hline $\begin{array}{l}\text { 15. obtain a job related } \\
\text { to the curriculum } \\
\text { studied at ScC }\end{array}$ & $\begin{array}{l}\text { Between grps } \\
\text { Within grps } \\
\text { Total }\end{array}$ & $\begin{array}{r}.8883 \\
155.1117 \\
156.0000\end{array}$ & $\begin{array}{r}2 \\
213 \\
215\end{array}$ & $\begin{array}{l}.4441 \\
.7882\end{array}$ & .6099 & .5444 \\
\hline $\begin{array}{l}\text { 16. transfer to a 4-year } \\
\text { college or university } \\
\text { and are academically } \\
\text { competitive with natives }\end{array}$ & $\begin{array}{l}\text { Between grps } \\
\text { Within grps } \\
\text { Total }\end{array}$ & $\begin{array}{r}9.3939 \\
250.5296 \\
259.9234\end{array}$ & $\begin{array}{r}2 \\
206\end{array}$ & $\begin{array}{l}4.6969 \\
1.2162\end{array}$ & 3.8621 & .0226 \\
\hline $\begin{array}{l}\text { 17. achieve employment } \\
\text { upgrade in their } \\
\text { current field of work }\end{array}$ & $\begin{array}{l}\text { Between grps } \\
\text { Within grps } \\
\text { Total }\end{array}$ & $\begin{array}{r}3.8166 \\
163.9973 \\
167.8140\end{array}$ & $\begin{array}{r}2 \\
212 \\
214\end{array}$ & $\begin{array}{r}1.9086 \\
.7736\end{array}$ & 2.4669 & .0873 \\
\hline
\end{tabular}


Table 27

Analysis of Variance for Student outcome Goals with

Groups Based on the Professional Role

(Continued)

\begin{tabular}{|c|c|c|c|c|c|c|}
\hline Outcome Goal & $\begin{array}{l}\text { Source of } \\
\text { Variation }\end{array}$ & $\begin{array}{l}\text { Sum of } \\
\text { Squares }\end{array}$ & DF & $\begin{array}{l}\text { Mean } \\
\text { Squares }\end{array}$ & $F$ & $\begin{array}{l}\text { F } \\
\text { Prob }\end{array}$ \\
\hline $\begin{array}{l}\text { 18. obtain certification } \\
\text { or licensure in their } \\
\text { profession }\end{array}$ & $\begin{array}{l}\text { Between grps } \\
\text { Within grps } \\
\text { Total }\end{array}$ & $\begin{array}{r}6.0254 \\
203.6538 \\
209.6792\end{array}$ & $\begin{array}{r}2 \\
209 \\
211\end{array}$ & $\begin{array}{r}3.0127 \\
.9744\end{array}$ & 3.0918 & .0475 \\
\hline $\begin{array}{l}\text { 19. obtain a high school } \\
\text { diploma or GED }\end{array}$ & $\begin{array}{l}\text { Between grps } \\
\text { Within grps } \\
\text { Total }\end{array}$ & $\begin{array}{r}3.5907 \\
221.5198 \\
225.1106\end{array}$ & $\begin{array}{r}2 \\
205\end{array}$ & $\begin{array}{l}1.7954 \\
1.0806\end{array}$ & 1.6155 & .1924 \\
\hline $\begin{array}{l}\text { 20. obtain an AS/AA or a } \\
1 \text { - or 2-year cert }\end{array}$ & $\begin{array}{l}\text { Between grps } \\
\text { Within grps } \\
\text { Total }\end{array}$ & $\begin{array}{r}1.8955 \\
162.8744 \\
164.7700\end{array}$ & $\begin{array}{r}2 \\
210 \\
212\end{array}$ & $\begin{array}{l}.9478 \\
.7756\end{array}$ & 1.2220 & .2967 \\
\hline $\begin{array}{l}\text { 21. obtain an scC } \\
\text { certificate }\end{array}$ & $\begin{array}{l}\text { Between grps } \\
\text { Within grps } \\
\text { Total }\end{array}$ & $\begin{array}{r}1.5876 \\
163.4077 \\
164.9953\end{array}$ & $\begin{array}{r}2 \\
209 \\
211\end{array}$ & $\begin{array}{l}.7938 \\
.7819\end{array}$ & 1.0153 & .3641 \\
\hline 22. obtain a BS/BA & $\begin{array}{l}\text { Between grps } \\
\text { Within grps } \\
\text { Total }\end{array}$ & $\begin{array}{r}2.6852 \\
205.9214 \\
208.6066\end{array}$ & $\begin{array}{r}2 \\
208\end{array}$ & $\begin{array}{l}1.3426 \\
.9900\end{array}$ & 1.3562 & .2599 \\
\hline $\begin{array}{l}\text { 23. transfer to a 4-year } \\
\text { college or university }\end{array}$ & $\begin{array}{l}\text { Between grps } \\
\text { Within grps } \\
\text { Total }\end{array}$ & $\begin{array}{r}2.5291 \\
189.1080 \\
185.1080\end{array}$ & $\begin{array}{r}2 \\
210 \\
212\end{array}$ & $\begin{array}{l}1.2646 \\
.8694\end{array}$ & 1.4545 & .2359 \\
\hline
\end{tabular}


In the secondary analysis, the scheffe multiple comparison procedure failed to determine which subgroups accounted for the significant differences in the means for Items $6,9,14$, and 18 .

The scheffé test determined which groups among the three subgroups accounted for the significant differences found in the ANOVA for Item 1 and 16. For (Item 1) students develop positive self-perceptions, the means of teachers ( $\mathbb{M}$ $=3.7226)$ were lower than those of support staff $(\underline{M}=$ 4.0000). For (Item 16) students transfer and compete, the means of teachers $(\underline{M}=2.8013)$ again were lower than the means of support staff $(\underline{M}=3.3704)$. Table 28 displays the means and indicates where significant differences exist.

\section{Research Question $5 b$}

Does the perceived importance of student outcome goals vary in relationship to the number of years worked in a community college?

Hypothesis 5b. There are no significant differences in the mean ratings on the 23 dependent variables (i.e., student outcome goals ratings) between stakeholders based on the number of years they worked in a community college.

This section presents the results concerning the relationship between number of years worked in a community college and the perceived importance of the outcome goals. In order to test Hypotheses 5b, the 23 dependent variables (i.e., the student outcome goals) were analyzed using a 
univariate, one-way analysis of variance design with the alpha level set at .05. The SPSS subprogram ONEWAY and Scheffé were used to look for significant differences in mean scores among the three groups: (a) 10 years or less, (b) 11 to 20 years, and (c) 21 or more years. Table 29 displays the results of the ANOVA.

\section{Table 28}

Scheffé Multiple Range Test of Differences Between Means for the Independent Variable Professional Role

\begin{tabular}{|c|c|c|c|c|}
\hline & & Teachers & Administrator & Support \\
\hline \multicolumn{5}{|c|}{$\begin{array}{l}\text { Item 1: develop } \\
\text { positive self-perceptions }\end{array}$} \\
\hline Mean & Group & & & \\
\hline $\begin{array}{l}3.7226 \\
3.8387 \\
4.0000\end{array}$ & $\begin{array}{l}\text { Teachers } \\
\text { In Admns } \\
\text { Support }\end{array}$ & $\star \star \star$ & & \\
\hline \multicolumn{5}{|c|}{$\begin{array}{l}\text { Item } 16: \text { transfer } \\
\& \text { compete } \mathrm{w} / \mathrm{natives}\end{array}$} \\
\hline Mean & Group & & & \\
\hline $\begin{array}{l}2.8013 \\
3.1613 \\
3.3704\end{array}$ & $\begin{array}{l}\text { Teachers } \\
\text { In Admns } \\
\text { Support }\end{array}$ & $\star \star \star *$ & & \\
\hline
\end{tabular}


Table 29

Analysis of Variance for student outcome Goals Between Groups Based on the Number of Years Worked in a Community College

\begin{tabular}{|c|c|c|c|c|c|c|}
\hline Outcome Goal & $\begin{array}{l}\text { Source of } \\
\text { Variation }\end{array}$ & $\begin{array}{l}\text { Sum of } \\
\text { Squares }\end{array}$ & $\mathrm{DF}$ & $\begin{array}{l}\text { Mean } \\
\text { Squares }\end{array}$ & $\mathbf{F}$ & $\begin{array}{l}\text { F } \\
\text { Prob }\end{array}$ \\
\hline $\begin{array}{l}\text { 1. develop positive } \\
\text { self-perceptions }\end{array}$ & $\begin{array}{l}\text { Between grps } \\
\text { Within grps } \\
\text { Total }\end{array}$ & $\begin{array}{l}.5077 \\
56.9438 \\
57.4515\end{array}$ & $\begin{array}{r}2 \\
234 \\
236\end{array}$ & $\begin{array}{l}.2539 \\
.2433\end{array}$ & 1.0432 & .3540 \\
\hline $\begin{array}{l}\text { 2. develop positive } \\
\text { behaviors }\end{array}$ & $\begin{array}{l}\text { Between grp } \\
\text { Within grps } \\
\text { Total }\end{array}$ & $\begin{array}{l}.2680 \\
70.1060 \\
70.3739\end{array}$ & $\begin{array}{r}2 \\
235 \\
237\end{array}$ & $\begin{array}{l}.1340 \\
.2983\end{array}$ & .4491 & .6387 \\
\hline $\begin{array}{l}\text { 3. acquire a foundation of } \\
\text { knowledge/skills that } \\
\text { helps them adapt to } \\
\text { new learning demands }\end{array}$ & $\begin{array}{l}\text { Between grps } \\
\text { Within grps } \\
\text { Total }\end{array}$ & $\begin{array}{l}.3700 \\
62.3473 \\
62.7173\end{array}$ & $\begin{array}{r}2 \\
234 \\
236\end{array}$ & $\begin{array}{l}.1850 \\
.2664\end{array}$ & .6943 & .5004 \\
\hline $\begin{array}{l}\text { 4. master a basic level } \\
\text { of skills in } \\
\text { reading, writing, math, } \\
\text { and language proficiency }\end{array}$ & $\begin{array}{l}\text { Between grps } \\
\text { Within grps } \\
\text { Total }\end{array}$ & $\begin{array}{r}3.6657 \\
95.0010 \\
98.6667\end{array}$ & $\begin{array}{r}2 \\
234 \\
236\end{array}$ & $\begin{array}{r}1.8328 \\
.4060\end{array}$ & 4.5145 & .0119 \\
\hline $\begin{array}{l}\text { 5. develop the skills to set } \\
\text { educational/career goals } \\
\text { for themselves }\end{array}$ & $\begin{array}{l}\text { Between grps } \\
\text { Within grps } \\
\text { Total }\end{array}$ & $\begin{array}{r}1.3137 \\
100.2846 \\
101.5983\end{array}$ & $\begin{array}{r}2 \\
236 \\
238\end{array}$ & $\begin{array}{l}.6569 \\
.4249\end{array}$ & 1.5458 & .2153 \\
\hline $\begin{array}{l}\text { 6. identify ed. / career } \\
\text { goals relevant to their } \\
\text { talents and abilities }\end{array}$ & $\begin{array}{l}\text { Between grps } \\
\text { Within grps } \\
\text { Total }\end{array}$ & $\begin{array}{r}1.2917 \\
105.7882 \\
107.00798\end{array}$ & $\begin{array}{r}2 \\
235 \\
237\end{array}$ & $\begin{array}{l}.6458 \\
.4502\end{array}$ & 1.4347 & .2403 \\
\hline
\end{tabular}


Table 29

Analysis of Variance for student Outcome Goals Between

Groups Based on the Number of Years Worked

in a Community college

(Continued)

\begin{tabular}{|c|c|c|c|c|c|c|}
\hline Outcome Goal & $\begin{array}{l}\text { Source of } \\
\text { Variation }\end{array}$ & $\begin{array}{l}\text { Sum of } \\
\text { Squares }\end{array}$ & DF & $\begin{array}{l}\text { Mean } \\
\text { Squares }\end{array}$ & $\mathbf{F}$ & $\begin{array}{l}\text { F } \\
\text { Prob }\end{array}$ \\
\hline $\begin{array}{l}\text { 7. achieve ed/career goals } \\
\text { they set for themselves }\end{array}$ & $\begin{array}{l}\text { Between grps } \\
\text { Within grps } \\
\text { Total }\end{array}$ & $\begin{array}{l}1.4969 \\
98.4656 \\
99.9625\end{array}$ & $\begin{array}{r}2 \\
237 \\
239\end{array}$ & $\begin{array}{l}.7484 \\
.4155\end{array}$ & 1.8015 & .1673 \\
\hline $\begin{array}{l}\text { 8. develop an intrinsic } \\
\text { appreciation of } \\
\text { learning }\end{array}$ & $\begin{array}{l}\text { Between grps } \\
\text { Within grps } \\
\text { Total }\end{array}$ & $\begin{array}{r}2.4619 \\
109.8220 \\
112.2839\end{array}$ & $\begin{array}{r}2 \\
233 \\
235\end{array}$ & $\begin{array}{r}1.2309 \\
.4713\end{array}$ & 2.6116 & .0756 \\
\hline $\begin{array}{l}\text { 9. develop values free } \\
\text { of ethnic, cultural, } \\
\text { and gender bias }\end{array}$ & $\begin{array}{l}\text { Between grps } \\
\text { Within grps } \\
\text { Total }\end{array}$ & $\begin{array}{r}2.3800 \\
149.6030 \\
151.9830\end{array}$ & $\begin{array}{r}2 \\
232 \\
234\end{array}$ & $\begin{array}{r}1.1900 \\
.6448\end{array}$ & 1.8454 & .1603 \\
\hline $\begin{array}{l}\text { 10. master course content } \\
\text { at a level set by } \\
\text { the instructor (s) }\end{array}$ & $\begin{array}{l}\text { Between grps } \\
\text { Within grps } \\
\text { Total }\end{array}$ & $\begin{array}{l}.2801 \\
83.5426 \\
83.8228\end{array}$ & $\begin{array}{r}2 \\
234 \\
236\end{array}$ & $\begin{array}{l}.1401 \\
.3570\end{array}$ & .3923 & .6759 \\
\hline $\begin{array}{l}\text { 11. develop the skills and } \\
\text { acquire the knowledge } \\
\text { base to succeed in more } \\
\text { advanced courses at SCC }\end{array}$ & $\begin{array}{l}\text { Between grps } \\
\text { within grps } \\
\text { Total }\end{array}$ & $\begin{array}{r}.4542 \\
146.2631 \\
146.7173\end{array}$ & $\begin{array}{r}2 \\
234 \\
235\end{array}$ & $\begin{array}{l}.2271 \\
.6251\end{array}$ & .3634 & .6957 \\
\hline $\begin{array}{l}\text { 12. complete the scc courses } \\
\text { for which they enroll }\end{array}$ & $\begin{array}{l}\text { Between grps } \\
\text { Within grps } \\
\text { Total }\end{array}$ & $\begin{array}{r}.0432 \\
136.0282 \\
136.0714\end{array}$ & $\begin{array}{r}2 \\
235 \\
237\end{array}$ & $\begin{array}{l}.0216 \\
.5788\end{array}$ & .0373 & .9634 \\
\hline
\end{tabular}


Table 29

Analysis of Variance for student Outcome Goals Between

Groups Based on the Number of Years Worked

in a Community college

(Continued)

\begin{tabular}{|c|c|c|c|c|c|c|}
\hline Outcome Goal & $\begin{array}{l}\text { Source of } \\
\text { Variation }\end{array}$ & $\begin{array}{l}\text { Sum of } \\
\text { Squares }\end{array}$ & DF & $\begin{array}{l}\text { Mean } \\
\text { Squares }\end{array}$ & $\mathbf{F}$ & $\begin{array}{l}\text { F } \\
\text { Prob }\end{array}$ \\
\hline $\begin{array}{l}\text { 13. maintain qualifications } \\
\text { for current job by } \\
\text { upgrading skills/knowl }\end{array}$ & $\begin{array}{l}\text { Between grps } \\
\text { Within grps } \\
\text { Total }\end{array}$ & $\begin{array}{r}2.4649 \\
188.8071 \\
191.2720\end{array}$ & $\begin{array}{r}2 \\
236 \\
238\end{array}$ & $\begin{array}{r}1.2325 \\
.8000\end{array}$ & 1.5405 & .2164 \\
\hline $\begin{array}{l}\text { 14. understand the } \\
\text { inter-relatedness of } \\
\text { our global society }\end{array}$ & $\begin{array}{l}\text { Between grps } \\
\text { Within grps } \\
\text { Total }\end{array}$ & $\begin{array}{r}3.2303 \\
197.5630 \\
200.7932\end{array}$ & $\begin{array}{r}2 \\
234 \\
236\end{array}$ & $\begin{array}{r}1.6151 \\
.8443\end{array}$ & 1.9130 & .1499 \\
\hline $\begin{array}{l}\text { 15. obtain a job related } \\
\text { to the curriculum } \\
\text { studied at SCC }\end{array}$ & $\begin{array}{l}\text { Between grps } \\
\text { Within grps } \\
\text { Total }\end{array}$ & $\begin{array}{r}2.8239 \\
167.9711 \\
170.7950\end{array}$ & $\begin{array}{r}2 \\
236 \\
238\end{array}$ & $\begin{array}{r}1.4119 \\
.7117\end{array}$ & 1.9838 & .1398 \\
\hline $\begin{array}{l}\text { 16. transfer to a 4-year } \\
\text { college or university } \\
\text { and are academically } \\
\text { competitive with natives }\end{array}$ & $\begin{array}{l}\text { Between grps } \\
\text { Within grps } \\
\text { Total }\end{array}$ & $\begin{array}{r}3.7965 \\
273.5801 \\
277.3766\end{array}$ & $\begin{array}{r}2 \\
228 \\
---\end{array}$ & $\begin{array}{l}1.8983 \\
1.1999\end{array}$ & 1.5820 & .2078 \\
\hline $\begin{array}{l}\text { 17. achieve employment } \\
\text { upgrade in their } \\
\text { current field of work }\end{array}$ & $\begin{array}{l}\text { Between grps } \\
\text { Within grps } \\
\text { Total }\end{array}$ & $\begin{array}{r}1.0944 \\
182.3941 \\
183.4895\end{array}$ & $\begin{array}{r}2 \\
236 \\
238\end{array}$ & $\begin{array}{l}.5472 \\
.7729\end{array}$ & .7080 & .4937 \\
\hline $\begin{array}{l}\text { 18. obtain certification } \\
\text { or licensure in their } \\
\text { profession }\end{array}$ & $\begin{array}{l}\text { Between grps } \\
\text { Within grps } \\
\text { Total }\end{array}$ & $\begin{array}{r}7.7297 \\
222.9342 \\
230.6638\end{array}$ & $\begin{array}{r}2 \\
232 \\
234\end{array}$ & $\begin{array}{r}3.8648 \\
.9609\end{array}$ & 4.0220 & .0192 \\
\hline
\end{tabular}


Table 29

Analysis of Variance for student Outcome Goals Between Groups Based on the Number of Years Worked

in a Community college

(Continued)

\begin{tabular}{|c|c|c|c|c|c|c|}
\hline Outcome Goal & $\begin{array}{l}\text { Source of } \\
\text { Variation }\end{array}$ & $\begin{array}{l}\text { Sum of } \\
\text { Squares }\end{array}$ & DF & $\begin{array}{l}\text { Mean } \\
\text { Squares }\end{array}$ & $\mathbf{F}$ & $\begin{array}{l}\text { F } \\
\text { Prob }\end{array}$ \\
\hline $\begin{array}{l}\text { 19. obtain a high school } \\
\text { diploma or GED }\end{array}$ & $\begin{array}{l}\text { Between grps } \\
\text { Within grps } \\
\text { Total }\end{array}$ & $\begin{array}{r}7.5134 \\
245.6641 \\
253.1775\end{array}$ & $\begin{array}{r}2 \\
228 \\
230\end{array}$ & $\begin{array}{l}3.7567 \\
1.0775\end{array}$ & 3.4866 & .0322 \\
\hline $\begin{array}{l}\text { 20. obtain an AS/AA or a } \\
1 \text { - or } 2 \text {-year cert }\end{array}$ & $\begin{array}{l}\text { Between grps } \\
\text { Within grps } \\
\text { Total }\end{array}$ & $\begin{array}{r}4.0917 \\
180.5636 \\
184.6553\end{array}$ & $\begin{array}{r}2 \\
232 \\
234\end{array}$ & $\begin{array}{r}2.0459 \\
.7783\end{array}$ & 2.6287 & .0743 \\
\hline $\begin{array}{l}\text { 21. obtain an SCC } \\
\text { certificate }\end{array}$ & $\begin{array}{l}\text { Between grps } \\
\text { Within grps } \\
\text { Total }\end{array}$ & $\begin{array}{r}6.7271 \\
188.0635 \\
194.7906\end{array}$ & $\begin{array}{r}2 \\
231 \\
233\end{array}$ & $\begin{array}{r}3.3635 \\
.8141\end{array}$ & 4.1315 & .0173 \\
\hline 22. obtain a BS/BA & $\begin{array}{l}\text { Between grps } \\
\text { Within grps } \\
\text { Total }\end{array}$ & $\begin{array}{r}1.8902 \\
230.3587 \\
232.2489\end{array}$ & $\begin{array}{r}2 \\
230 \\
232\end{array}$ & $\begin{array}{r}.9451 \\
1.0016\end{array}$ & .9436 & .3907 \\
\hline $\begin{array}{l}\text { 23. transfer to a } 4 \text {-year } \\
\text { college or university }\end{array}$ & $\begin{array}{l}\text { Between grps } \\
\text { Within grps } \\
\text { Total }\end{array}$ & $\begin{array}{r}4.1926 \\
198.3074 \\
202.5000\end{array}$ & $\begin{array}{r}2 \\
231 \\
233\end{array}$ & $\begin{array}{r}2.0963 \\
.8585\end{array}$ & 2.4419 & .0892 \\
\hline
\end{tabular}


Using the 23 outcome goals as the dependent variables and the number of yearss worked in a community college as the independent variables, the statistical hypothesis that there would be no significant: difference between the means of the three groups was confirmed for 19 of the 23 variables.

The hypothesis was rejected for four variables. In this first level of analysis, the ANOVA rejected the hypothesis for the following variables:

(Item 4) students master a basic level of skills in reading, writing, math, and language proficiency-with $\underline{f}(1)=4.5145, \underline{p}<.0119$;

(Item 18) students obtain certification or licensure in their profession--with $\underline{f}(1)=4.0220, \underline{E}<.0192$;

(Item 19) students obtain a high school diploma or GED--with $\underline{f}(1)=3.4866, \underline{p}<.0322 ;$ and

(Item 21) Students obtain an SCC certificate--with $\underline{f}(1)=$ $4.1315, \mathrm{E}<.0173$.

In the secondary analysis, the scheffe multiple comparison procedure failed to determine differences between the means of the groups for Item 19. However, the Scheffé did determine between which groups differences existed for Items 4,18 , and 21 . Discussion of the results of the scheffe for these items follow Table 29.

The Scheffé test was used on Items 4,18 and 21 to 1ook for significant differences in the means among the three subgroups. All of the relationships in this set of analyses 
were between the subgroup which had worked 10 or fewer years and the subgroup which had worked 11 to 20 years. The group that had worked the shortest period of time rated each of the items significantly higher than the other group. The means on each of the items for these subgroups follows: (Item 4) students master basic skills--the mean for stakeholders who had worked 10 or less $(M=$ 3.8052) differed significantly from the mean for stakeholders who had worked 11 to 21 years $(\underline{M}=$ $3.5455) ;$

(Item 18) students get license or certificate--the mean for stakeholders who had worked 10 or less years $(\underline{M}=$ 3.1154) differed significantly from those who had worked 11 to 21 years $(\underline{M}=2.7119)$;

(Item 21) Students obtain a 1- or 2-year certificate-the mean for stakeholders who had worked 10 or less years $(\underline{M}=2.8289)$ was significantly different from those who had worked 11 or more years $(\underline{M}=$ $2.4790)$.

Table 30 shows each of these dependent variables, the means for each subgroup, and the indicates the subgroups between which significant differences exist. 
Table 30

Scheffé Multiple Range Test of Differences Between Means for the Independent Variable Number of Years Worked in a Community College

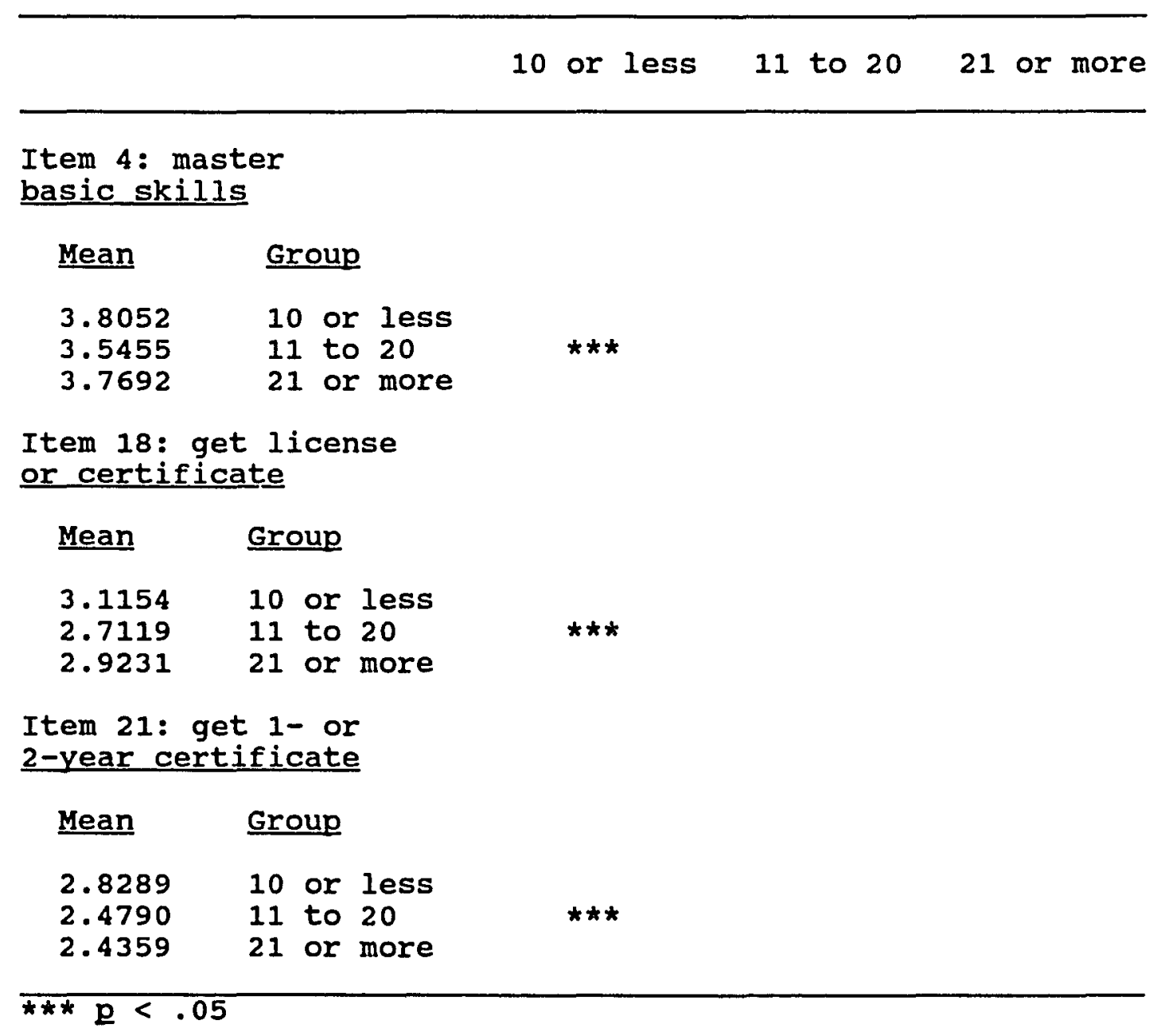

Research Question $5 \mathrm{c}$

Does the perceived importance of the student outcome goals vary in relationship to the number of years worked at SCC?

Hypothesis 5c: There are no significant differences in the mean ratings on the 23 dependent variables (i.e., 
student outcome goals ratings) between stakeholders based on the number of years they worked at scC.

In order to test Hypothesis 5c, the 23 dependent variables (i.e., the student outcomes goals) were analyzed using a univariate, one-way analysis of variance with the alpha level set at .05. The SPSS subprogram ONEWAY and the scheffé multiple comparison procedure were used to perform an analysis using the recoded number of years worked as the independent variable and the means of the outcome goals as the dependent variables. The statistical hypothesis that there would be no significant difference between the means of the three groups was confirmed for 22 items because no significant differences were found among the means. The hypothesis was rejected for (Item 4) "students master a basic level of skills in reading, writing, math, and language proficiency" with $\underline{f}(1)$ $=4.1453, \mathrm{~g}<.0170$. Table 31 shows the results of the ANOVA for each dependent variable.

The number of years worked at sunrise Community college was related to only one of the 23 dependent variables, Item 4. The Scheffe test was used on item 4 to look for significant differences in the mean among the three groups: (a) 10 years or less, (b) 11 to 20 years, and (c) 21 or more years. Table 32 shows the means of each group and indicates that mean of stakeholders who had worked 10 years or less $(\underline{M}=3.7732)$ was higher than the mean for stakeholders who had worked 11 to 20 years $(\underline{M}=3.5294)$. 
Table 31

Analysis of Variance for student outcome Goals between Groups Based on the Number of Years Worked at SCC

\begin{tabular}{|c|c|c|c|c|c|c|}
\hline Outcome Goal & $\begin{array}{l}\text { Source of } \\
\text { Variation }\end{array}$ & $\begin{array}{l}\text { Sum of } \\
\text { Squares }\end{array}$ & DF & $\begin{array}{l}\text { Mean } \\
\text { Squares }\end{array}$ & $\mathbf{F}$ & $\begin{array}{l}\text { F } \\
\text { Prob }\end{array}$ \\
\hline $\begin{array}{l}\text { 1. develop positive } \\
\text { self-perceptions }\end{array}$ & $\begin{array}{l}\text { Between grps } \\
\text { Within grps } \\
\text { Total }\end{array}$ & $\begin{array}{r}.6816 \\
56.7699 \\
57.4515\end{array}$ & $\begin{array}{r}2 \\
234 \\
236\end{array}$ & $\begin{array}{l}.3408 \\
.2426\end{array}$ & 1.4047 & .2475 \\
\hline $\begin{array}{l}\text { 2. develop positive } \\
\text { behaviors }\end{array}$ & $\begin{array}{l}\text { Between grps } \\
\text { Within grps } \\
\text { Total }\end{array}$ & $\begin{array}{r}.2729 \\
70 \cdot 1010 \\
70.3739\end{array}$ & $\begin{array}{r}2 \\
235 \\
237\end{array}$ & $\begin{array}{l}.1365 \\
.2983\end{array}$ & .4575 & .6335 \\
\hline $\begin{array}{l}\text { 3. acquire a foundation of } \\
\text { knowledge/skills that } \\
\text { helps them adapt to } \\
\text { new learning demands }\end{array}$ & $\begin{array}{l}\text { Between grps } \\
\text { Within grps } \\
\text { Total }\end{array}$ & $\begin{array}{r}.4633 \\
62.2540 \\
62.7173\end{array}$ & $\begin{array}{r}2 \\
234 \\
236\end{array}$ & $\begin{array}{l}.2316 \\
.2660\end{array}$ & .8707 & .4200 \\
\hline $\begin{array}{l}\text { 4. master a basic level } \\
\text { of skills in } \\
\text { reading, writing, math, } \\
\text { and language proficiency }\end{array}$ & $\begin{array}{l}\text { Between grps } \\
\text { within grps } \\
\text { Total }\end{array}$ & $\begin{array}{r}3.3762 \\
95.2905 \\
98.6667\end{array}$ & $\begin{array}{r}2 \\
234 \\
236\end{array}$ & $\begin{array}{r}1.6881 \\
.4072\end{array}$ & 4.1453 & .0170 \\
\hline $\begin{array}{l}\text { 5. develop the skills to set } \\
\text { educational/career goals } \\
\text { for themselves }\end{array}$ & $\begin{array}{l}\text { Between grps } \\
\text { within grps } \\
\text { Total }\end{array}$ & $\begin{array}{r}1.5753 \\
100.0230 \\
101.5983\end{array}$ & $\begin{array}{r}2 \\
236 \\
238\end{array}$ & $\begin{array}{l}.7877 \\
.4238\end{array}$ & 1.8585 & .1582 \\
\hline $\begin{array}{l}\text { 6. identify ed./career } \\
\text { goals relevant to their } \\
\text { talents and abilities }\end{array}$ & $\begin{array}{l}\text { Between grps } \\
\text { within grps } \\
\text { Total }\end{array}$ & $\begin{array}{c}1.0517 \\
106.0282 \\
107.0798\end{array}$ & $\begin{array}{r}2 \\
235 \\
237\end{array}$ & $\begin{array}{l}.5258 \\
.4512\end{array}$ & 1.1654 & .3136 \\
\hline
\end{tabular}


Table 31

Analysis of Variance for student outcome Goals between Groups Based on the Number of Years Worked at SCC

(Continued)

\begin{tabular}{|c|c|c|c|c|c|c|}
\hline Outcome Goal & $\begin{array}{l}\text { Source of } \\
\text { Variation }\end{array}$ & $\begin{array}{l}\text { Sum of } \\
\text { Squares }\end{array}$ & DF & $\begin{array}{l}\text { Mean } \\
\text { Squares }\end{array}$ & $\mathbf{F}$ & $\begin{array}{l}\text { F } \\
\text { Prob }\end{array}$ \\
\hline $\begin{array}{l}\text { 7. achieve ed/career goals } \\
\text { they set for themselves }\end{array}$ & $\begin{array}{l}\text { Between grps } \\
\text { within grps } \\
\text { Total }\end{array}$ & $\begin{array}{r}1.8150 \\
98.1475 \\
99.9625\end{array}$ & $\begin{array}{r}2 \\
237 \\
239\end{array}$ & $\begin{array}{l}.9075 \\
.4141\end{array}$ & 2.1913 & .1140 \\
\hline $\begin{array}{l}\text { 8. develop an intrinsic } \\
\text { appreciation of } \\
\text { learning }\end{array}$ & $\begin{array}{l}\text { Between grps } \\
\text { Within grps } \\
\text { Total }\end{array}$ & $\begin{array}{r}2.2151 \\
110.0688 \\
112.2839\end{array}$ & $\begin{array}{r}2 \\
233 \\
235\end{array}$ & $\begin{array}{r}1.1076 \\
.4724\end{array}$ & 2.3445 & .0982 \\
\hline $\begin{array}{l}\text { 9. develop values free } \\
\text { of ethnic, cultural, } \\
\text { and gender bias }\end{array}$ & $\begin{array}{l}\text { Between grps } \\
\text { Within grps } \\
\text { Total }\end{array}$ & $\begin{array}{r}3.0947 \\
148.8882 \\
151.9830\end{array}$ & $\begin{array}{r}2 \\
232\end{array}$ & $\begin{array}{r}1.5474 \\
.6418\end{array}$ & 2.4111 & .0920 \\
\hline $\begin{array}{l}\text { 10. master course content } \\
\text { at a level set by } \\
\text { the instructor (s) }\end{array}$ & $\begin{array}{l}\text { Between grps } \\
\text { within grps } \\
\text { Total }\end{array}$ & $\begin{array}{r}.6163 \\
83.2065 \\
83.8228\end{array}$ & $\begin{array}{r}2 \\
234 \\
236\end{array}$ & $\begin{array}{l}.3081 \\
.3556\end{array}$ & .8665 & .4217 \\
\hline $\begin{array}{l}\text { 11. develop the skills and } \\
\text { acquire the knowledge } \\
\text { base advance at scc }\end{array}$ & $\begin{array}{l}\text { Between grps } \\
\text { Within grps } \\
\text { Total }\end{array}$ & $\begin{array}{l}.7189 \\
145.9984 \\
146.7173\end{array}$ & $\begin{array}{r}2 \\
234 \\
236\end{array}$ & $\begin{array}{l}.3595 \\
.6239\end{array}$ & .5761 & .5629 \\
\hline $\begin{array}{l}\text { 12. complete the scc courses } \\
\text { for which they enroll }\end{array}$ & $\begin{array}{l}\text { Between grps } \\
\text { Within grps } \\
\text { Total }\end{array}$ & $\begin{array}{r}.3278 \\
137.1680 \\
137.4958\end{array}$ & $\begin{array}{r}2 \\
235 \\
237\end{array}$ & $\begin{array}{l}.1639 \\
.5837\end{array}$ & .2808 & .7555 \\
\hline
\end{tabular}


Table 31

Analysis of Variance for student outcome Goals between Groups Based on the Number of Years Worked at SCC

(Continued)

\begin{tabular}{|c|c|c|c|c|c|c|}
\hline Outcome Goal & $\begin{array}{l}\text { Source of } \\
\text { Variation }\end{array}$ & $\begin{array}{l}\text { Sum of } \\
\text { Squares }\end{array}$ & DF & $\begin{array}{l}\text { Mean } \\
\text { Squares }\end{array}$ & $\mathbf{F}$ & $\begin{array}{l}\text { F } \\
\text { Prob }\end{array}$ \\
\hline $\begin{array}{l}\text { 13. maintain qualifications } \\
\text { for current job by } \\
\text { upgrading skills/knowl }\end{array}$ & $\begin{array}{l}\text { Between grps } \\
\text { Within grps } \\
\text { Total }\end{array}$ & $\begin{array}{r}2.2229 \\
189.6516 \\
191.8745\end{array}$ & $\begin{array}{r}2 \\
236 \\
238\end{array}$ & $\begin{array}{r}1.1115 \\
.8036\end{array}$ & 1.3831 & .2528 \\
\hline $\begin{array}{l}\text { 14. understand the } \\
\text { inter-relatedness of } \\
\text { our global society }\end{array}$ & $\begin{array}{l}\text { Between grps } \\
\text { Within grps } \\
\text { Total }\end{array}$ & $\begin{array}{l}3.9361 \\
196.8571 \\
200.7932\end{array}$ & $\begin{array}{c}2 \\
234 \\
236\end{array}$ & $\begin{array}{r}1.9681 \\
.8413\end{array}$ & 2.3394 & .0986 \\
\hline $\begin{array}{l}\text { 15. obtain a job related } \\
\text { to the curriculum } \\
\text { studied at SCC }\end{array}$ & $\begin{array}{l}\text { Between grps } \\
\text { Within grps } \\
\text { Total }\end{array}$ & $\begin{array}{r}1.2665 \\
169.5285 \\
170.7950\end{array}$ & $\begin{array}{r}2 \\
236 \\
238\end{array}$ & $\begin{array}{l}.6333 \\
.7183\end{array}$ & .8816 & .4155 \\
\hline $\begin{array}{l}\text { 16. transfer to a } 4 \text {-year } \\
\text { college or university } \\
\text { and compete w/natives }\end{array}$ & $\begin{array}{l}\text { Between grps } \\
\text { Within grps } \\
\text { Total }\end{array}$ & $\begin{array}{r}3.2281 \\
276.7979 \\
280.0260\end{array}$ & $\begin{array}{r}2 \\
228 \\
230\end{array}$ & $\begin{array}{l}1.6140 \\
1.2140\end{array}$ & 1.3295 & .2667 \\
\hline $\begin{array}{l}\text { 17. achieve employment } \\
\text { upgrade in their } \\
\text { current field of work }\end{array}$ & $\begin{array}{l}\text { Between grps } \\
\text { Within grps } \\
\text { Total }\end{array}$ & $\begin{array}{r}1.5327 \\
181.6221 \\
183.1548\end{array}$ & $\begin{array}{r}2 \\
236 \\
268\end{array}$ & $\begin{array}{l}.7664 \\
.7696\end{array}$ & .9958 & .3710 \\
\hline $\begin{array}{l}\text { 18. obtain certification } \\
\text { or licensure in their } \\
\text { profession }\end{array}$ & $\begin{array}{l}\text { Between grps } \\
\text { Within grps } \\
\text { Total }\end{array}$ & $\begin{array}{r}2.9184 \\
228.5028 \\
231.4213\end{array}$ & $\begin{array}{r}2 \\
232 \\
234\end{array}$ & $\begin{array}{r}1.4592 \\
.9849\end{array}$ & 1.4815 & .2294 \\
\hline
\end{tabular}


Table 31

Analysis of Variance for student outcome Goals between Groups Based on the Number of Years Worked at SCC

(Continued)

\begin{tabular}{|c|c|c|c|c|c|c|}
\hline Outcome Goal & $\begin{array}{l}\text { Source of } \\
\text { Variation }\end{array}$ & $\begin{array}{l}\text { Sum of } \\
\text { Squares }\end{array}$ & $\mathrm{DF}$ & $\begin{array}{l}\text { Mean } \\
\text { Squares }\end{array}$ & $\mathbf{F}$ & $\begin{array}{l}\text { F } \\
\text { Prob }\end{array}$ \\
\hline $\begin{array}{l}\text { 19. obtain a high school } \\
\text { diploma or GED }\end{array}$ & $\begin{array}{l}\text { Between grps } \\
\text { Within grps } \\
\text { Total }\end{array}$ & $\begin{array}{r}5.6423 \\
247.5352 \\
253.1775\end{array}$ & $\begin{array}{r}2 \\
228 \\
230\end{array}$ & $\begin{array}{l}2.8211 \\
1.0857\end{array}$ & 2.5985 & .0766 \\
\hline $\begin{array}{l}\text { 20. obtain an AS/AA or a } \\
1 \text { - or } 2 \text {-year cert }\end{array}$ & $\begin{array}{l}\text { Between grps } \\
\text { Within grps } \\
\text { Total }\end{array}$ & $\begin{array}{r}3.1404 \\
191.8172 \\
194.9573\end{array}$ & $\begin{array}{r}2 \\
231 \\
233\end{array}$ & $\begin{array}{r}1.5700 \\
.8304\end{array}$ & 1.8907 & .1533 \\
\hline $\begin{array}{l}\text { 21. obtain an SCC } \\
\text { certificate }\end{array}$ & $\begin{array}{l}\text { Between grps } \\
\text { Within grps } \\
\text { Total }\end{array}$ & $\begin{array}{r}1.9013 \\
183.2732 \\
185.1745\end{array}$ & $\begin{array}{r}2 \\
232 \\
234\end{array}$ & $\begin{array}{l}.9506 \\
.7900\end{array}$ & 1.2034 & .3020 \\
\hline 22. obtain a BS/BA & $\begin{array}{l}\text { Between grps } \\
\text { within grps } \\
\text { Total }\end{array}$ & $\begin{array}{r}3.0140 \\
229.2263 \\
232.2403\end{array}$ & $\begin{array}{r}2 \\
230 \\
232\end{array}$ & $\begin{array}{r}1.5070 \\
.9966\end{array}$ & 1.5121 & .2226 \\
\hline $\begin{array}{l}\text { 23. transfer to a 4-year } \\
\text { college or university }\end{array}$ & $\begin{array}{l}\text { Between grps } \\
\text { Within grps } \\
\text { Total }\end{array}$ & $\begin{array}{r}4.6512 \\
199.8317 \\
204.4829\end{array}$ & $\begin{array}{r}2 \\
231 \\
233\end{array}$ & $\begin{array}{r}2.3256 \\
.8651\end{array}$ & 2.6883 & .0701 \\
\hline
\end{tabular}


Table 32
Scheffé Multiple Range Test of Differences Between Means for the Independent Variable Number of Years Worked at SCC

Item 4: master basic

level of skills

Mean Group

3.773210 or less

$3.5294 \quad 11$ to $20 \quad * * *$

$3.7732 \quad 21$ or more

$\star \star * * \mathbf{p}<.05$

Research Question 5d

Does the perceived importance of the student outcome goals vary in relationship to campus assignment?

Null hypothesis 5d. There are no significant differences in the mean ratings on the 23 dependent variables (i.e., student outcome goals ratings) between stakeholders who work primarily at Riverview, Extended Campus, Brooklyn, and Meadowland.

This section presents the results concerning the relationship between stakeholders' campus location and the perceived importance of the outcome goals. In order to test Hypotheses 5d, the scores on the 23 items in the student Outcome Goals Inventory were used as the dependent variables and the "campus location" of the respondent was used as the 
independent variable. The dependent variables were analyzed using a univariate, one-way analysis of variance design with the alpha level set at .05. The statistical null hypothesis that there would be no significant differences between the means of the four campus subgroups was confirmed for all 23 dependent variables. Table 33 presents the results of the analysis of variance for the 23 dependent variables. Because no significant differences were found between groups on any of the dependent variables, the scheffé test was not performed.

\section{Research Question $5 \mathrm{e}$}

Does the perceived importance of student outcome goals vary in relationship to gender?

Null hypothesis 5e. There are no significant difference in the mean ratings on the 23 dependent variables (i.e., student outcome goals ratings) between stakeholders who are male and female.

This section presents the results concerning the relationship between gender and the perceived importance of the outcome goals. In order to test Null Hypotheses 5e, the 23 dependent variables (i.e., the student outcome goals) were analyzed using a $t$ test with the alpha level set at .05. The SPSS subprogram $\underline{T}$ TEST was performed to determine whether significant differences existed between the mean scores of males and females. Table 34 presents means and standard deviations for males and females on each outcome 
Table 33

Analysis of Variance for student Outcome Goals Between Groups Based on the Campus Location

\begin{tabular}{|c|c|c|c|c|c|c|}
\hline Outcome Goal & $\begin{array}{l}\text { Source of } \\
\text { Variation }\end{array}$ & $\begin{array}{l}\text { Sum of } \\
\text { Squares }\end{array}$ & $\mathrm{DF}$ & $\begin{array}{l}\text { Mean } \\
\text { Squares }\end{array}$ & $\mathbf{F}$ & $\begin{array}{l}\text { F } \\
\text { Prob }\end{array}$ \\
\hline $\begin{array}{l}\text { 1. develop positive } \\
\text { self-perceptions }\end{array}$ & $\begin{array}{l}\text { Between grps } \\
\text { Within grps } \\
\text { Total }\end{array}$ & $\begin{array}{r}1.0450 \\
56.3617 \\
57.4068\end{array}$ & $\begin{array}{r}3 \\
232 \\
235\end{array}$ & $\begin{array}{l}.3483 \\
.2429\end{array}$ & 1.4339 & .2336 \\
\hline $\begin{array}{l}\text { 2. develop positive } \\
\text { behaviors }\end{array}$ & $\begin{array}{l}\text { Between grps } \\
\text { Within grps } \\
\text { Total }\end{array}$ & $\begin{array}{r}.5816 \\
69.7306 \\
70.3122\end{array}$ & $\begin{array}{r}3 \\
233 \\
236\end{array}$ & $\begin{array}{l}.1939 \\
.2993\end{array}$ & .6478 & .5851 \\
\hline $\begin{array}{l}\text { 3. acquire a foundation of } \\
\text { knowledge/skills that } \\
\text { helps them adapt to } \\
\text { new learning demands }\end{array}$ & $\begin{array}{l}\text { Between grps } \\
\text { Within grps } \\
\text { Total }\end{array}$ & $\begin{array}{l}.2939 \\
62.3501 \\
62.6441\end{array}$ & $\begin{array}{r}3 \\
232 \\
235\end{array}$ & $\begin{array}{l}.0980 \\
.2688\end{array}$ & .3646 & .7787 \\
\hline $\begin{array}{l}\text { 4. master a basic level } \\
\text { of skills in } \\
\text { reading, writing, math, } \\
\text { and language proficiency }\end{array}$ & $\begin{array}{l}\text { Between grps } \\
\text { Within grps } \\
\text { Total }\end{array}$ & $\begin{array}{l}.2947 \\
169.5541 \\
169.8487\end{array}$ & $\begin{array}{r}3 \\
234 \\
237\end{array}$ & $\begin{array}{l}.0982 \\
.7246\end{array}$ & .1356 & .9388 \\
\hline $\begin{array}{l}\text { 5. develop the skills to set } \\
\text { educational/career goals } \\
\text { for themselves }\end{array}$ & $\begin{array}{l}\text { Between grps } \\
\text { Within grps } \\
\text { Total }\end{array}$ & $\begin{array}{r}.6851 \\
100.5124 \\
100.1975\end{array}$ & $\begin{array}{r}3 \\
234 \\
237\end{array}$ & $\begin{array}{l}.2284 \\
.4295\end{array}$ & .5316 & .6610 \\
\hline $\begin{array}{l}\text { 6. identify ed./career } \\
\text { goals relevant to their } \\
\text { talents and abilities }\end{array}$ & $\begin{array}{l}\text { Between grps } \\
\text { Within grps } \\
\text { Total }\end{array}$ & $\begin{array}{r}1.0807 \\
105.8391 \\
106.9198\end{array}$ & $\begin{array}{r}3 \\
233 \\
236\end{array}$ & $\begin{array}{l}.3602 \\
.4542\end{array}$ & .7931 & .4988 \\
\hline
\end{tabular}


Table 33

Analysis of Variance for student outcome Goals Between Groups Based on the Campus Location

(Continued)

\begin{tabular}{|c|c|c|c|c|c|c|}
\hline outcome Goal & $\begin{array}{l}\text { Source of } \\
\text { Variation }\end{array}$ & $\begin{array}{l}\text { Sum of } \\
\text { Squares }\end{array}$ & DF & $\begin{array}{l}\text { Mean } \\
\text { Squares }\end{array}$ & $\mathbf{F}$ & $\begin{array}{l}\text { F } \\
\text { Prob }\end{array}$ \\
\hline $\begin{array}{l}\text { 7. achieve ed/career goals } \\
\text { they set for themselves }\end{array}$ & $\begin{array}{l}\text { Between grps } \\
\text { Within grps } \\
\text { Total }\end{array}$ & $\begin{array}{l}.1936 \\
99.5470 \\
99.7406\end{array}$ & $\begin{array}{r}3 \\
235 \\
238\end{array}$ & $\begin{array}{l}.0645 \\
.4236\end{array}$ & .1523 & .9281 \\
\hline $\begin{array}{l}\text { 8. develop an intrinsic } \\
\text { appreciation of } \\
\text { learning }\end{array}$ & $\begin{array}{l}\text { Between grps } \\
\text { Within grps } \\
\text { Total }\end{array}$ & $\begin{array}{r}.4653 \\
111.6198 \\
112.0851\end{array}$ & $\begin{array}{r}3 \\
231 \\
234\end{array}$ & $\begin{array}{l}.1551 \\
.4832\end{array}$ & .3210 & .8102 \\
\hline $\begin{array}{l}\text { 9. develop values free } \\
\text { of ethnic, cultural, } \\
\text { and gender bias }\end{array}$ & $\begin{array}{l}\text { Between grps } \\
\text { Within grps } \\
\text { Total }\end{array}$ & $\begin{array}{r}2.0140 \\
149.8151 \\
151.8291\end{array}$ & $\begin{array}{r}3 \\
230 \\
233\end{array}$ & $\begin{array}{l}.6713 \\
.6514\end{array}$ & 1.0306 & .3798 \\
\hline $\begin{array}{l}\text { 10. master course content } \\
\text { at a level set by } \\
\text { the instructor (s) }\end{array}$ & $\begin{array}{l}\text { Between grps } \\
\text { Within grps } \\
\text { Total }\end{array}$ & $\begin{array}{r}.5816 \\
69.7306 \\
70.3122\end{array}$ & $\begin{array}{r}3 \\
233 \\
236\end{array}$ & $\begin{array}{l}.1939 \\
.2993\end{array}$ & .6478 & .5851 \\
\hline $\begin{array}{l}\text { 11. develop the skills and } \\
\text { acquire the knowledge } \\
\text { base to succeed in more } \\
\text { advanced courses at SCC }\end{array}$ & $\begin{array}{l}\text { Between grps } \\
\text { Within grps } \\
\text { Total }\end{array}$ & $\begin{array}{r}.2381 \\
145.9441 \\
146.1822\end{array}$ & $\begin{array}{r}3 \\
232 \\
235\end{array}$ & $\begin{array}{l}.0794 \\
.6291\end{array}$ & .1262 & .9445 \\
\hline $\begin{array}{l}\text { 12. complete the SCC courses } \\
\text { for which they enroll }\end{array}$ & $\begin{array}{l}\text { Between grps } \\
\text { Within grps } \\
\text { Total }\end{array}$ & $\begin{array}{r}1.5105 \\
134.5148 \\
136.0253\end{array}$ & $\begin{array}{r}3 \\
233 \\
236\end{array}$ & $\begin{array}{l}.5035 \\
.5773\end{array}$ & .8722 & .4562 \\
\hline
\end{tabular}


Table 33

Analysis of Variance for student Outcome Goals Between Groups Based on the Campus Location (Continued)

\begin{tabular}{|c|c|c|c|c|c|c|}
\hline Outcome Goal & $\begin{array}{l}\text { Source of } \\
\text { Variation }\end{array}$ & $\begin{array}{l}\text { Sum of } \\
\text { squares }\end{array}$ & $\mathrm{DF}$ & $\begin{array}{l}\text { Mean } \\
\text { Squares }\end{array}$ & $\mathbf{F}$ & $\begin{array}{l}\text { F } \\
\text { Prob }\end{array}$ \\
\hline $\begin{array}{l}\text { 13. maintain qualifications } \\
\text { for current job by } \\
\text { upgrading skills/knowl }\end{array}$ & $\begin{array}{l}\text { Between grps } \\
\text { Within grps } \\
\text { Total }\end{array}$ & $\begin{array}{r}3.1714 \\
189.3833 \\
192.5546\end{array}$ & $\begin{array}{r}3 \\
234 \\
237\end{array}$ & $\begin{array}{r}1.0571 \\
.8093\end{array}$ & 1.3062 & .2731 \\
\hline $\begin{array}{l}\text { 14. understand the } \\
\text { inter-relatedness of } \\
\text { our global society }\end{array}$ & $\begin{array}{l}\text { Between grps } \\
\text { Within grps } \\
\text { Total }\end{array}$ & $\begin{array}{r}1.8266 \\
198.9658 \\
200.7924\end{array}$ & $\begin{array}{r}3 \\
232 \\
235\end{array}$ & $\begin{array}{l}.6089 \\
.8576\end{array}$ & .7099 & .5469 \\
\hline $\begin{array}{l}\text { 15. obtain a job related } \\
\text { to the curriculum } \\
\text { studied at SCC }\end{array}$ & $\begin{array}{l}\text { Between grps } \\
\text { Within grps } \\
\text { Total }\end{array}$ & $\begin{array}{l}.3553 \\
83.3226 \\
83.6780\end{array}$ & $\begin{array}{r}3 \\
232 \\
235\end{array}$ & $\begin{array}{l}.1184 \\
.3591\end{array}$ & .3298 & .8038 \\
\hline $\begin{array}{l}\text { 16. transfer to a } 4 \text {-year } \\
\text { college or university } \\
\text { and are academically } \\
\text { competitive with natives }\end{array}$ & $\begin{array}{l}\text { Between grps } \\
\text { Within grps } \\
\text { Total }\end{array}$ & $\begin{array}{l}.7362 \\
278.4117 \\
279.1478\end{array}$ & $\begin{array}{r}3 \\
226 \\
229\end{array}$ & $\begin{array}{r}.2454 \\
1.2319\end{array}$ & .1992 & .8969 \\
\hline $\begin{array}{l}\text { 17. achieve employment } \\
\text { upgrade in their } \\
\text { current field of work }\end{array}$ & $\begin{array}{l}\text { Between grps } \\
\text { Within grps } \\
\text { Total }\end{array}$ & $\begin{array}{r}4.1045 \\
180.2148 \\
184.3193\end{array}$ & $\begin{array}{r}3 \\
234 \\
237\end{array}$ & $\begin{array}{r}1.3682 \\
.7701\end{array}$ & 1.7765 & .1523 \\
\hline $\begin{array}{l}\text { 18. obtain certification } \\
\text { or licensure in their } \\
\text { profession }\end{array}$ & $\begin{array}{l}\text { Between grps } \\
\text { Within grps } \\
\text { Total }\end{array}$ & $\begin{array}{r}1.1099 \\
229.0439 \\
230.1538\end{array}$ & $\begin{array}{r}3 \\
230 \\
233\end{array}$ & $\begin{array}{l}.3700 \\
.9958\end{array}$ & .3715 & .7736 \\
\hline
\end{tabular}


Table 33

Analysis of Variance for student outcome Goals Between Groups Based on the Campus Location

(Continued)

\begin{tabular}{|c|c|c|c|c|c|c|}
\hline Outcome Goal & $\begin{array}{l}\text { Source of } \\
\text { Variation }\end{array}$ & $\begin{array}{l}\text { Sum of } \\
\text { Squares }\end{array}$ & DF & $\begin{array}{l}\text { Mean } \\
\text { Squares }\end{array}$ & $\mathbf{F}$ & $\begin{array}{l}\text { F } \\
\text { Prob }\end{array}$ \\
\hline $\begin{array}{l}\text { 19. obtain a high school } \\
\text { diploma or GED }\end{array}$ & $\begin{array}{l}\text { Between grps } \\
\text { Within grps } \\
\text { Total }\end{array}$ & $\begin{array}{r}2.4072 \\
251.5754 \\
253.9826\end{array}$ & $\begin{array}{r}3 \\
226 \\
239\end{array}$ & $\begin{array}{r}.8024 \\
1.1132\end{array}$ & .7208 & .5405 \\
\hline $\begin{array}{l}\text { 20. obtain an AS/AA or a } \\
1 \text { - or } 2 \text {-year cert }\end{array}$ & $\begin{array}{l}\text { Between grps } \\
\text { Within grps } \\
\text { Total }\end{array}$ & $\begin{array}{r}3.1299 \\
180.9427 \\
184.9427\end{array}$ & $\begin{array}{r}3 \\
230 \\
233\end{array}$ & $\begin{array}{r}1.0433 \\
.7867\end{array}$ & 1.3262 & .2666 \\
\hline $\begin{array}{l}\text { 21. obtain an SCC } \\
\text { certificate }\end{array}$ & $\begin{array}{l}\text { Between grps } \\
\text { Within grps } \\
\text { Total }\end{array}$ & & & & & \\
\hline 22. obtain a BS/BA & $\begin{array}{l}\text { Between grps } \\
\text { Within grps } \\
\text { Total }\end{array}$ & $\begin{array}{r}1.9119 \\
230.0881 \\
232.0000\end{array}$ & $\begin{array}{r}3 \\
228 \\
231\end{array}$ & $\begin{array}{r}.6373 \\
1.0092\end{array}$ & .6315 & .5954 \\
\hline $\begin{array}{l}\text { 23. transfer to a } 4 \text {-year } \\
\text { college or university }\end{array}$ & $\begin{array}{l}\text { Between grps } \\
\text { within grps } \\
\text { Total }\end{array}$ & $\begin{array}{r}1.3965 \\
202.8524 \\
204.2489\end{array}$ & $\begin{array}{r}3 \\
229 \\
232\end{array}$ & $\begin{array}{l}.4655 \\
.8858\end{array}$ & .5255 & .6652 \\
\hline
\end{tabular}


Table 34

$t$ Test Comparison of Means for student Outcome Goals Based on Gender

\begin{tabular}{|c|c|c|c|c|c|c|c|c|}
\hline \multirow[b]{2}{*}{ Outcome Goal } & \multicolumn{2}{|c|}{ Females } & \multicolumn{4}{|c|}{ Males } & \multirow{2}{*}{$\begin{array}{l}t- \\
\text { value }\end{array}$} & \multirow{2}{*}{$\begin{array}{l}2- \\
\text { tail } \\
\text { prob }\end{array}$} \\
\hline & $\underline{\mathbf{n}}$ & Mean & $(\mathrm{SD})$ & $\underline{\mathbf{n}}$ & Mean & $(S D)$ & & \\
\hline $\begin{array}{l}\text { 1. develop positive } \\
\text { self-perceptions }\end{array}$ & 117 & 3.8803 & .419 & 120 & 3.7000 & .544 & 2.86 & .005 \\
\hline $\begin{array}{l}\text { 2. develop positive } \\
\text { behaviors }\end{array}$ & 116 & 3.7845 & .524 & 122 & 3.7213 & .564 & .89 & .427 \\
\hline $\begin{array}{l}\text { 3. acquire foundation } \\
\text { of knowledge/skills } \\
\text { to adapt to new } \\
\text { learning demands }\end{array}$ & 115 & 3.7652 & .484 & 122 & 3.6967 & .544 & 1.02 & .206 \\
\hline $\begin{array}{l}\text { 4. master basic level } \\
\text { of skills } \\
\text { in reading, writing, } \\
\text { math, \& lang prof }\end{array}$ & 115 & 3.6522 & .676 & 122 & 3.6803 & .620 & -.33 & .350 \\
\hline $\begin{array}{l}\text { 5. develop skills to } \\
\text { set ed/career goals }\end{array}$ & 117 & 3.7009 & .647 & 122 & 3.5656 & .655 & 1.61 & .887 \\
\hline $\begin{array}{l}\text { 6. identify ed/career } \\
\text { goals relevant to } \\
\text { talents \& abilities }\end{array}$ & 116 & 3.6466 & .676 & 122 & 3.5574 & .669 & 1.02 & .908 \\
\hline
\end{tabular}


Table 34

$\underline{t}$ Test Comparison of Means for Student Outcome Goals Based on Gender

(Continued)

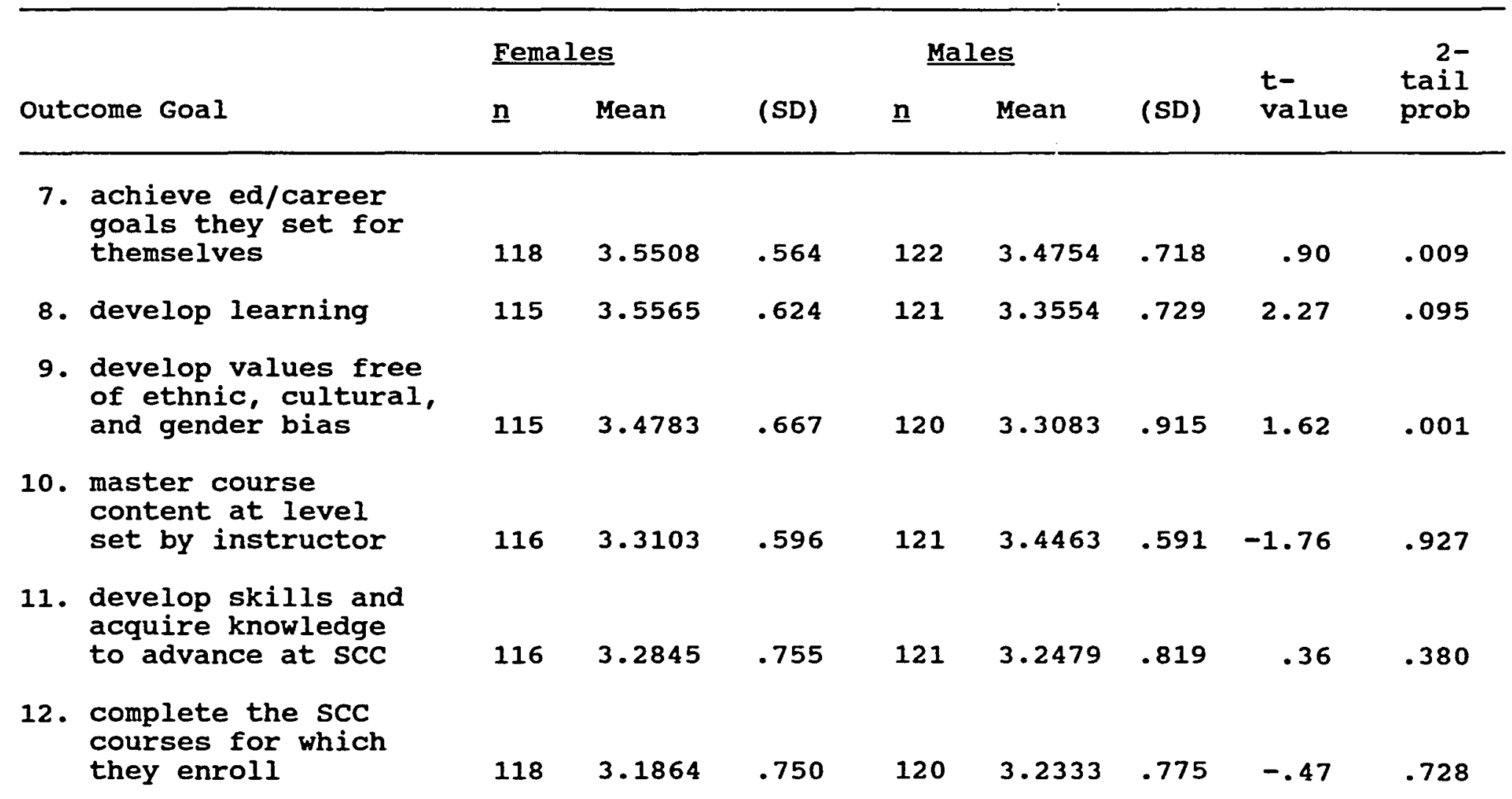


Table 34

$\underline{t}$ Test Comparison of Means for student

Outcome Goals Based on Gender

(Continued)

\begin{tabular}{|c|c|c|c|c|c|c|c|c|}
\hline \multirow[b]{2}{*}{ Outcome Goal } & \multicolumn{2}{|c|}{ Females } & \multicolumn{4}{|c|}{ Males } & \multirow{2}{*}{$\begin{array}{l}t- \\
\text { value }\end{array}$} & \multirow{2}{*}{$\begin{array}{l}2- \\
\text { tail } \\
\text { prob }\end{array}$} \\
\hline & $\underline{\mathbf{n}}$ & Mean & (SD) & $\underline{\mathbf{n}}$ & Mean & (SD) & & \\
\hline $\begin{array}{l}\text { 13. maintain current job } \\
\text { qualifications by } \\
\text { upgrading skills } \\
\text { and knowledge }\end{array}$ & 118 & 3.1186 & .980 & 121 & 3.1736 & .813 & -.47 & .043 \\
\hline $\begin{array}{l}\text { 14. understand the } \\
\text { inter-relatedness of } \\
\text { our global society }\end{array}$ & 116 & 3.1379 & .913 & 121 & 2.9339 & .929 & 1.71 & .853 \\
\hline $\begin{array}{l}\text { 15. obtain a job related } \\
\text { to the curriculum } \\
\text { studied at SCC }\end{array}$ & 117 & 3.0085 & .866 & 122 & 3.0492 & .832 & -.37 & .660 \\
\hline $\begin{array}{l}\text { 16. transfer to a 4-year } \\
\text { college/university } \\
\text { \& compete with } \\
\text { natives }\end{array}$ & 112 & 2.8661 & 1.127 & 119 & 3.0252 & 1.069 & -1.10 & .573 \\
\hline $\begin{array}{l}\text { 17. achieve employment } \\
\text { upgrade in their } \\
\text { current field of } \\
\text { work }\end{array}$ & 117 & 2.9145 & .896 & 122 & 2.9180 & .868 & -.03 & .729 \\
\hline
\end{tabular}


Table 34

$t$ Test Comparison of Means for Student

Outcome Goals Based on Gender

(Continued)

\begin{tabular}{|c|c|c|c|c|c|c|c|c|}
\hline \multirow[b]{2}{*}{ oưtcōmé Goài } & \multicolumn{3}{|c|}{ Females } & \multicolumn{2}{|c|}{ Males } & \multirow[b]{2}{*}{ (SD) } & \multirow{2}{*}{$\begin{array}{l}t- \\
\text { value }\end{array}$} & \multirow{2}{*}{$\begin{array}{r}2- \\
\text { tail } \\
\text { prob }\end{array}$} \\
\hline & $\underline{\mathbf{n}}$ & Mean $^{-}$ & $(S D)$ & $\underline{\mathbf{n}}$ & Mean & & & \\
\hline $\begin{array}{l}\text { 18. obtain certification } \\
\text { or licensure in } \\
\text { their profession }\end{array}$ & 116 & 2.8793 & .979 & 119 & 2.8655 & 1.008 & .11 & .759 \\
\hline $\begin{array}{l}\text { 19. obtain a high school } \\
\text { diploma or GED }\end{array}$ & 114 & 2.7368 & 1.056 & 117 & 2.8291 & 1.045 & -.67 & .904 \\
\hline $\begin{array}{l}\text { 20. obtain an AS/AA or a } \\
1 \text {-or-yr certificate }\end{array}$ & 114 & 2.6842 & .855 & 121 & 2.8264 & .919 & -1.23 & .439 \\
\hline $\begin{array}{l}\text { 21. obtain an } s c c \\
\text { certificate }\end{array}$ & 114 & 2.5702 & .902 & 120 & 2.5917 & .930 & -.18 & .741 \\
\hline 22. obtain a BS/BA & 114 & 2.3860 & .982 & 119 & 2.6134 & 1.001 & -1.75 & .841 \\
\hline 23. transfer & 115 & 2.4087 & .907 & 119 & 2.5882 & .951 & -1.48 & .608 \\
\hline
\end{tabular}


goal and the $t$-values for the different scores, based on data from the total sample. As the table reveals, significant differences were found on two items:

(Item 1) students develop positive self-perceptions--with the mean for females $(\underline{M}=3.8803)$ significantly higher than for males $(\underline{M}=3.7000), \underline{p}<.005$, and

(Item 9) Students develop values free of ethnic, cultural, and gender bias--with the mean for females $(\underline{M}=$ 3.4784) significantly higher than for males $(\underline{M}=$ $3.3083), \mathrm{p}<.001$.

\section{Summary}

This chapter described the results of statistical analysis guided by the five research questions regarding the relative importance instructional stakeholders assign to 23 student outcomes for the students they serve most often, whether inter-relationships existed among sets of outcomes which represent single constructs, whether subgroups among instructional stakeholders differ in these perceptions, and whether the outcomes valued by instructional stakeholders could be predicted based on the type of student served. The variables used were: (a) type of student served most often, (b) professional role, (c) number of years worked in a community college, (d) number of years worked at SCC, (e) campus location, (f) gender, and (g) 23 different student outcome goals. 
The major /findings of the study were: (a) Instructional stakeholders as a group perceive seven outcomes to be most important--developing positive selfperceptions, developing positive behaviors (e.g., honest), developing learning skills, mastering basic skills, developing skills to set educational and career goals, and achieving educational and career goals; (b) The 23 outcomes are represented by six factors or effectiveness domains-Personal/Social Outcomes, Employment Outcomes, Traditional College Outcomes, and Developmental Outcomes; (c) "Type of student served" has a significant relationship to the perceived importance of 12 of the 23 outcomes with most differences occurring between stakeholders serving lower division transfer students and those serving professional/technical students; (d) The type of students stakeholders serve can be predicted with $69 \%$ accuracy with stakeholders' responses to the outcomes "transfer and compete with natives," "obtain BA/BS," and "obtain professional certification" contributing most to the predictive function; and (e) Very few significant relationships exist between the remaining biographical variables and the 23 outcome variables. 


\section{CHAPTER V}

\section{CONCLUSTONS}

This chapter begins with a set of general conclusions and then addresses each|Research Question posed for the study. For each question, the author briefly reviews the major findings from chapter IV, interprets the findings, and discusses the implications of the findings particularly as they relate to developing an outcomes assessment program at Sunrise Community College.

\section{General Conclusions}

Given the diverse mission of the community college and the strident controversy in the literature related to the community college's appropriate mission, one would anticipate that a large, urban community college such as Sunrise Community college would be composed of separate camps of stakeholders with distinct goals for students. This research finds, however, that stakeholders were unified in their view that the most important outcomes for their students relate to acquiring a set of foundation skills and attitudes in the personal/social and developmental domains. The author refers to the seven most highly rated outcomes as foundation skills because they form the basis of knowledge, 
skills, and attitudes that must be present in order for students to successfully engage in traditional postsecondary education programs in both the professional/technical and lower division transfer arenas. While clear consensus existed as to the high degree of importance of the foundation outcomes, outcomes in the credentialing, transfer, and employment domains were perceived as having varying degrees of importance by subgroups within the college.

For the most part, the foundation outcomes have been overlooked by federal and state mandates and are given short shrift in accreditation standards. Outcomes assessment in the community college has focused on the credentialing, transfer, and employment domains. It is likely that this has occurred for two reasons. First, assessment programs have typically developed in response to demands by external । entities, such as legislatures, rather than from internal, grassroots initiatives and these bodies have not required information on foundation outcomes, perhaps because they assume that these skills have already been developed through high school. Second, the credentialing, transfer, and employment outcomes are relatively easy and inexpensive to measure.

The dichotomy between the external assessment mandates and internal stakeholder values is potentially problematic. If the purpose of educational evaluation is to meet the 
information needs of stakeholders so that they are better able to make improvements in curriculum and services to students, then these mandates are failing to address a very critical area of concern for instructional stakeholders at scc. Colleges which focus on externally mandated outcomes at the expense of the outcomes that are most highly valued by their instructional stakeholders are missing an opportunity to use assessment to answer questions about student achievement that are very meaningful to these stakeholders. The college's efforts to assess these meaningful outcomes would most likely increase stakeholder "buy-in" for an assessment program and lead to greater willingness to use assessment results for improvement purposes.

The outcomes targeted in the Educational Reform Act adopted by the state in which SCC is located are more closely aligned with SCC stakeholders' values than are most external mandates (Oregon Department of Education, 1993). The state plan specifically targets some foundation outcomes identified as very important by stakeholders in this study. Furthermore, it calls for directly measuring and certifying these competencies while moving away from the traditional measures of educational effectiveness, such as the high school diploma and grades. This correspondence between SCC stakeholders' values and the Educational Reform Act's goals for students may signal that the community college faculty, 
administrators, and support staff at SCC are in the vanguard in terms of supporting the goals of the reform plan. At the least, it indicates a close and comfortable alignment between the values identified in this study and the state's reform agenda.

The groups which were least like each other in terms of the goals they perceive as valuable for students were lower division transfer stakeholders and professional/technical stakeholders. Although they shared values in terms of the foundation skills, the lower division transfer stakeholders valued transfer outcomes more highly while the professional/technical stakeholders valued employment outcomes more highly. These findings are not surprising.

The two groups historically have had distinct missions. State and national reform initiatives (e.g., the state's Educational Reform initiative, the federal SCANS competencies and the Education Goals for the Year 2000); however, may bring the two closer together. These reform initiatives stress the importance of integrating "academic" competencies into the professional/technical curriculum to meet the challenges of training workers for the highly technological and rapidly changing future world of work. At the same time, these initiatives focus lower division transfer programs on the goal of developing the most competitive workforce in the world. 
Conclusions Related to the Research Questions

In light of these general conclusions, the question arises as to how SCC can employ these findings in their efforts to develop an effective outcomes assessment program. The following sections address each research question individually delving more deeply into the meaning of the findings and their application to the problems of developing an outcomes assessment program.

\section{Research Question 1}

of the wide array of student outcomes that are perceived by instructional stakeholders to be relevant for students in community colleges, which do instructional stakeholders as a whole perceive to be most important?

An examination of the descriptive statistics revealed that instructional stakeholders as a whole did value some student outcomes more highly than others. Those outcomes held to be most important tended to be associated with the outcomes that Astin (1991, p. 45) grouped under affective/psychological or affective/behavioral. Those that were least highly valued by the group as a whole were associated with the outcomes Astin grouped under cognitive/behavioral (see Table 3 ). It should be noted that none of the outcomes was rated not important. This result is not surprising given that the inventory of outcomes used in the survey instrument was developed through focus group 
research which collected items for the inventory from the surveyed population. of interest, then, was not whether extremes of not important and very important could be found. Rather, the study sought to explore the relative importance the group as a whole ascribed to each of the 23 outcomes and whether any meaningful patterns could be deduced from the data.

The study found that 15 out of the 23 were rated moderately to very important. of these 15 outcomes, seven were rated more than moderately important. These were:

1. students develop positive self-perceptions;

2. students develop positive behaviors (e.g., honesty)

3. students acquire a foundation of knowledge/skills that helps them adapt to new learning demands;

4. students master a basic level of skills in reading, writing, math and language proficiency;

5. students develop the skills to set educational/career goals;

6. students identify educational/career goals for themselves

7. students achieve educational/career goals they set for themselves.

Figure 2 graphs the outcomes according to their overall rating the whole group. 


\section{Student Outcome Goals Variables}

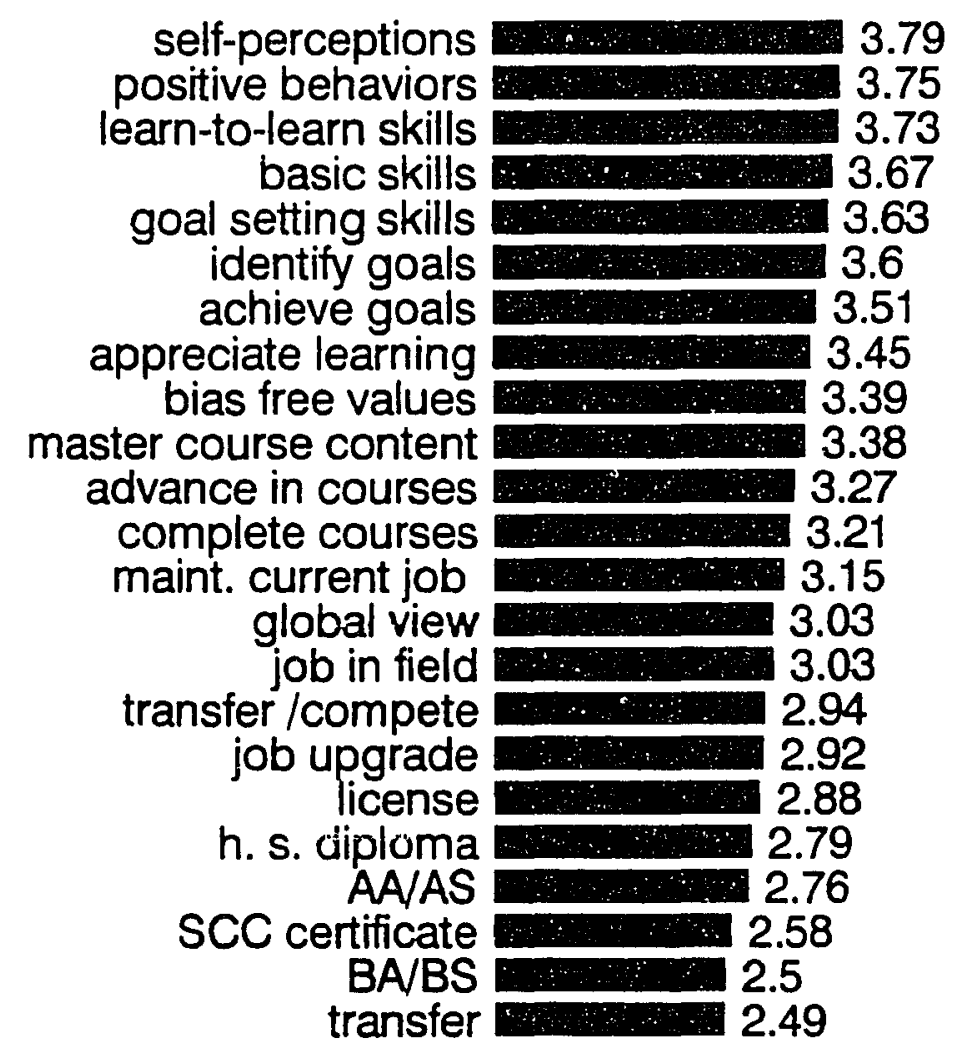

Figure 2. Outcome goals for the whole group: means ranked in descending order.

The standard deviations of these seven items ranged from .49 to .67 . The author cites the standard deviations because the size of the standard deviation is a rough gauge of the degree of agreement among respondents regarding each item. The smaller the standard deviation, the more consensus exists among individuals in the sample population; the larger the standard deviation, the less consensus exists. For the seven outcomes that were most important, the small standard deviations indicate considerable 
consensus within the sample as to the outcomes' importance. Another gauge of consensus within the sample is the number of significant differences between groups that can be identified for each outcome variable. For the seven highest rated outcomes, very few statistically significant differences existed. This paucity of significant differences supports the assertion that a relatively high degree of consensus exists among instructional stakeholders regarding the importance of these highest rated outcomes. only eight outcomes were rated less than moderately important. The standard deviations for these items ranged from .88 to 1.10 , relatively large standard deviations. For these outcomes, the deduction drawn from the existence of larger standard deviations is that the low ratings were a consequence of wide disparity between individual respondents. The eight least important outcomes were also items for which a larger number of statistically significant differences were found, particularly between stakeholders sorted by the type of student served most often. The eight least important outcomes were:

16. students transfer to a 4-year college or university and are academically competitive;

17. students achieve an employment upgrade in their work;

18. students obtain professional certification/ licensure; 
19. students obtain a high school diploma or GED;

20. students obtain an AA/AS or a 1- or 2-year

certificate;

21. students obtain an SCC certificate;

22. students obtain a BA/BS;

23. students transfer to a 4-year college or

university.

Implications. The seven outcomes rated most important, and enjoying a relatively high degree of consensus, were associated with changes in student behavior or attitude related to affect, goal setting and achievement, and basic skill development.

About affective outcomes, Astin (1991) wrote:

Educators are inclined to shy away from assessing affective outcomes because they think they are too value-laden. They feel much more comfortable limiting their assessments to cognitive outcomes. College, they argue, is supposed to develop the student's intellect, so how can we go wrong if we focus on cognitive variables? However . . . most colleges claim to be concerned about such affective qualities as good judgment, citizenship, social responsibility, and character. Under these conditions, no program of student outcomes assessment would seem complete without due consideration for assessment of relevant affective outcomes. (p. 44)

Astin's (1991) assertion was based on his readings of college catalogues and mission statements and his presumption that colleges should assess the changes they claim they effect in students. The findings of this study support Astin's assertion, at least as they apply to sunrise 
Community college. Like the formal documents Astin consulted, the mission statement at SCC makes similar claims, and scc's faculty, support staff, and instructional administrators agree that certain affective outcomes are very important for their students.

In addition to the affective and behavioral outcomes included in the top seven most important outcomes, the research revealed that three other outcomes from the affective/psychological domain were rated moderately important by the group as a whole. These were: (a) developing an intrinsic appreciation of learning; (b) developing values free of ethnic, cultural, and gender bias; and (c) understanding the inter-relatedness of our global society.

The two outcomes that were not affective constructs in the set of seven most highly rated outcomes constructs were "students master a basic level of skills in reading, writing, math and language proficiency," and "students develop the skills to set educational and career goals for themselves." These are outcomes that can be defined by specific sets of knowledge and skill competencies. They can also be thought of as developmental--that is, outcomes students typically are expected to have mastered as a result of a sound secondary education.

The researcher has engaged in informal discussions with community college practitioners at SCC and across the nation 
regarding the reason that these particular seven outcomes were selected as most important for students to achieve. A common response both locally and nationally to this question was that an exceptional number of community college students enter institutions without the attitudes, behaviors, and basic skills required for success in traditional programs. The seven highest rated outcomes constitute the foundation upon which students' future academic success depends. The directions on the questionnaire that collected the data for this study asked that, when rating the importance of the 23 outcomes, the respondent consider "the students with whom [they] work most often." It appears that community college practitioners perceive that an overwhelming number of students with whom they work most often have not acquired the necessary foundation for success in traditional community college programs and classes and, furthermore, that they understand that providing such a foundation is their first order of business as teachers, administrators, and support staff.

Several critical issues related to the development of assessment programs in community colleges are informed by this finding. Kinnick and Walleri (1991) refer to outcomes that reflect behavioral changes associated with affect as "behavioral constructs" (p. 109). From this study, some examples of such behavioral constructs are: students develop positive perceptions of themselves; students develop 
positive behaviors such as initiative, honesty; students develop an intrinsic appreciation for learning; and students understand the inter-relationship of our global society.

In terms of assessing behavioral constructs, Kinnick and Walleri (1991) make several important points. First, they assert, "construct behaviors apply to all students but are not necessarily a consequence of a specific class, discipline, or other college experience" (p. 110). One implication of this observation is that it is not appropriate to analyze such outcomes at the individual course or program level of analysis. Rather, such constructs would be more appropriately analyzed at SCC at a college-wide level of aggregation. In addition, it is possible that sunrise community college could explore analyzing these outcomes at the first level of organization below the whole-institution level. This would mean examining affective construct outcomes by the three major educational subdivisions: lower division college, professional/technical education, and developmental education.

Second, Kinnick and Walleri (1991) believe that assessment of affective behavioral constructs "requires institutional consensus, which may be difficult to achieve" (p. 110). One of the major stumbling blocks to assessing construct behaviors at the college-wide level of aggregation can be lack of consensus. The results of this study, 
however, indicate that among the stakeholders at sunrise Community College substantial consensus already exists college-wide as to the importance and value of affective behavioral construct outcomes.

Another important point made by Kinnick and walleri (1991) is that practitioners "should have some reasonable set of evidence that the behaviors and skills of interest can be affected by the college experience" (p. 109). Stakeholders' initial selection of construct outcomes included in the outcomes inventory (and later the instrument) can be interpreted to mean that they believe the constructs should and can be affected by the community college educational experience. Explaining how stakeholders believe curriculum and activities affect these constructs was not an aim of this study; however, it is an important area of scholarship. Determining the contribution of educational experiences to affective behavioral and attitudinal changes is no easy task. Intervening variables, unrelated to education, may confound attempts to assign causes. Sunrise Community college is advised to explore this issue in some depth in preparation for designing assessment measures of these outcomes.

Finally, Kinnick and Walleri (1991) point out that "some behaviors and performances cannot be assessed adequately until the student has moved beyond the educational experience" (p. 110). An outcome from this 
study that serves as an example is the third highest rated outcome, "students acquire a foundation of knowledge and skills that helps them adapt to new learning demands." Although this outcome can be assessed by observing students' ability to apply learning skills in subsequent courses, it might be better evaluated in real life settings, such as on the job, than in the artificial environment of the classroom.

\section{Research Question 2}

Can the 23 student outcome goals be factored into a smaller number of underlying constructs or dimensions?

From the 23 outcome goals, the factor analysis extracted six factors. These factors represented clearly identifiable constructs. These constructs were: Personal/ Social Development Outcomes, Transfer outcomes, Credentialing Outcomes, Employment Outcomes, Traditional College Learning outcomes, and Developmental Skills outcomes.

Three outcomes contributed to the first factor, Personal/Social Development Outcomes. Moreover, the three outcome goals that were most highly rated by stakeholders as a whole contributed to this factor. These were: (a) developing positive self-perceptions, (b) developing positive behaviors, and (c) acquiring a foundation of knowledge/skills that helps students adapt to new learning demands. The other three variables contributing to the 
first factor were the remaining values-oriented affective outcomes included in the inventory: (a) developing values free of ethnic, cultural, and gender bias; (b) developing an understanding of the inter-relatedness of global society; and (c) developing an appreciation for learning. One conclusion that can be drawn from this analysis is that, for the stakeholders at SCC, the three top rated outcomes were closely associated with the other affective, values oriented outcomes in the inventory. This suggests that these outcomes could make up a subscale in an assessment instrument aimed at measuring what is in effect a single construct--Personal/Social Development.

By and large, the outcome variables that contributed to the other factors are intuitively logical. All variables related to transfer and the baccalaureate experience contributed to the factor Transfer Outcomes. All variables related to getting degrees, certificates, and professional credentials contributed to the factor credentialing outcomes. All variables related to job attainment or maintenance contributed to the factor Employment outcomes. The variables which specifically addressed completing courses and mastering course content contributed to the factor Traditional college outcomes, and the variables "students master basic skills" and "students develop skills necessary to advance in SCC classes" contributed to the factor Developmental outcomes. 
While the variables listed above fell neatly into factors that intuitively make sense, the grouping of the three variables related to educational and career goals were less easily explained. While it might be expected that these three variables would constitute a separate factor, they were associated as follows:

1. students develop the skills to set educational and career goals contributed to Traditional college outcomes;

2. students set educational and career goals contributed to | Developmental Outcomes;

3. students achieve educational and career goals contributed to Employment Outcomes. The distribution of these variables among different $/$ factors indicates that they were perceived by the stakeholders as distinct outcome goals rather than as dimensions of the same outcome.

Implications. The interpretation of the results of the factor analysis suggests a practical application. The researcher recommends that the institution conceptually organize an outcomes assessment program around the constructs represented by the factors. The variables subsumed under each factor could be assessed individually, but with the understanding that they reflect dimensions of a unifying construct. The six factors, in essence, become organizing principles of the outcomes assessment plan. one can think of each factor outcome as one plank of the 
institution's effectiveness platform. Together the six factor outcomes, which the author will call effectiveness domains, would represent in abstract, global terms (and serve as categories for) the whole array of student outcomes the institution chooses to foster and assess.

Within each of these effectiveness domains, would be a set of effectiveness indicators composed of some or all of the outcome goals that contributed to the factor. Initially, the college would assess and report individual outcome goals grouped under their effectiveness domains. But over time it is possible that the college could develop a single composite indicator (something like a composite score) for each effectiveness domain, derived from combining the results of the individual outcomes grouped under each domain.

While the development of a composite indicator for each effectiveness domain would be a long range goal, a more immediate and more critical aim would be for programs to set a standard for each individual outcome goal that the institution chose to assess. An educational indicator is:

a statistic that tells something about the performance or health of the education system. For a statistic to be an indicator, it must have a standard against which it can be judged. (Oakes, 1986, p. vii)

Most likely, before such judgment could be rendered, the institution would record and compare assessment results over 
a period of time in order to have baseline data from which standards of effectiveness could be determined.

An outcomes assessment program organized in this way allows for great flexibility. If one thinks of an outcomes assessment program as an organic system developing precision and sophistication over time, the use of effectiveness domains is an ideal framework. Initially, specific outcome goals can be grouped under their appropriate domains, and the institution can concentrate on developing methods to assess these. The results can be aggregated institutionwide or by organizational units, as appropriate. Groups of results can be reported under their effectiveness domains. The advantage of this approach is that there is more than one measure of effectiveness for each domain. Multiple measures ensure a more valid reflection of reality. For example, under the effectiveness domain Employment outcomes, four outcome goals could be measured and reported: (a) maintaining job qualifications, (b) achieving employment upgrades, (c) obtaining jobs in fields related to study at SCC, and (d) achieving the educational and career goals students have set for themselves. The college may find students are highly successful with some outcomes and less successful in the other(s). The college could report that it is effective in this domain, overall, but that some outcomes should be targeted for improvement.

Table 35 lists the Outcome Domains. 
Table 35

Effectiveness Domains and Student outcome Goals

Effectiveness

Domain

Rankoutcome
Personal/
Social
(1) develop positive self-perceptions
(2) develop positive behaviors
(3) acquire skills to learn
(8) develop appreciation of learning
(9) develop bias free values
(14) understand interrelationship of global society
Transfer
(16) transfer and compete with natives
(22) obtain BA/BS
(23) transfer
Credentialing (18) obtain prof certification/license
(19) obtain high school diploma/GED
(20) obtain AA/AS
(21) obtain 1- or 2-year certificate
Employment (7) achieve ed/career goals
(13) maintain job qualifications
(15) obtain job related to fld of study
(17) achieve employment upgrade
Traditional
College
(5) develop skills to set ed/career goals
(10) master course content
(12) complete courses in which enrolled
Developmental (4) master basic skills
(5) identify ed/career goal
(6) develop skills to advance in other courses at SCC

\section{Research Question 3}

Does the perceived importance of student outcomes vary in relationship to the type of student the stakeholder serves most often? 
The type of student served most often was the demographic variable for which the most statistically significant differences in the perceived importance of outcome goals was found. For 12 of the 23 outcomes, analysis of variance found significant differences between group means for one or more subgroups and the Scheffe identified the group(s) between which the differences existed.

For all but one of the outcomes in the Personal/Social Outcomes Domain, no significant differences were found. There are six individual outcomes in this domain, and all but one were among the top 10 outcomes rated most important for the group as a whole. The high overall ratings that the whole group gave the outcomes in this domain and the fact that seven out of the eight outcomes did not produce significant differences among stakeholders suggests that the college can develop assessment measures for the outcomes in this domain with a high level of assurity that they are viewed as important by instructional stakeholders serving all four subgroups of students. Table 36 displays the outcomes on which subgroups differed organized by Effectiveness Domain: 
Table 36

Student Outcome Goals for Which Differences

Were Found: Type of Studerit Served

Effectiveness

Domain and Number of

Possible Differences Outcome for Which Differences Found

\begin{tabular}{ll}
\hline $\begin{array}{l}\text { Personal/Social } \\
6\end{array}$ & $(8)$ develop appreciation of learning \\
Transfer & $(16)$ transfer and compete with natives \\
3 & $(22)$ obtain BA/BS \\
& $(23)$ transfer \\
Credentialing & $(18)$ obtain prof certification/license \\
4 & $(19)$ obtain high school diploma/GED \\
& $(20)$ obtain AA/AS \\
& $(21)$ obtain 1- or 2-year certificate \\
Employment & $(13)$ maintain job qualifications \\
& $(15)$ obtain job related to fld of study \\
Traditional & $(17)$ achieve employment upgrade \\
3 & \\
Dellege & $(10)$ master course content \\
3 &
\end{tabular}

Note: Type of student served subgroups were Lower Division Transfer, Professional/Technical, Developmental, and Combined.

The one item within the Personal/social Domain that produced statistically significant differences was "students develop an appreciation of learning." stakeholders serving LDT and Combined groups of students rated this outcome significantly more important than did PTE-serving stakeholders. Educators who have analyzed the changing 
labor market and the increased use of technology, which is itself changing rapidly, have predicted that workers in the U.S. will be required to engage in lifelong learning to maintain jobs (Parnell, 1994). Given this prediction, it may be of concern to the college that instructional stakeholders serving professional/technical students find developing an intrinsic appreciation for learning less important than do stakeholders serving other groups. The college could initiate a staff development campaign to educate instructors about the changing requirements for lifelong learning and specifically target this group of stakeholders for training.

statistically significant differences were found for all of the outcomes in the Transfer Outcomes Domain. For each outcome, LDT-serving stakeholders perceived the outcome as significantly more important than combined-serving, professional-technical serving, or developmental-serving stakeholders. Combined-serving stakeholders, however, also rated the transfer outcomes significantly more important than the professional/technical-serving stakeholders. Many professional/technical programs at the community college are considered terminal and typically do not serve as gateways to baccalaureate institutions, however, increasingly many are transfer oriented. Professional/technical-serving stakeholders should be encouraged to discuss the reasons that they as a group viewed obtaining a BA/BS degree as less 
than even mildly important $(\underline{M}=1.9549)$ for their students. It terms of designing an assessment program, the institution must be aware that transfer has relatively low importance to stakeholders serving professional/technical students and should track the transfer activity of these students in order to collect information which faculty may need in order to understand the transfer goals of their students.

All of the outcomes in the credentialing outcomes Domain produced statistically significant differences. For each outcome, the professional/technical-serving stakeholders rated the importance as significantly higher than did the LDT-serving stakeholders.

one finding related to this domain that should be of concern to the college is the relatively low rating that LDT-serving stakeholders gave the outcome "students obtain an associate degree." These stakeholders rated the outcome as only mildly important $(\underline{M}=2.4074)$. As described in Chapter III, earning an associate degree is a major outcome examined by external agencies in evaluating the effectiveness of community colleges. The associate degree is formal acknowledgment that the student has completed a two-year program of study, but many transfer students leave the college without the AA/AS or certificate. with this in mind, SCC may consider initiating a staff development campaign aimed at increasing the LDT-serving stakeholders' understanding of the value of the associate degree and 
encouraging them to recommend to their students that they include earning an AA/AS in their educational goals.

All but one of the four outcomes in the Employment Outcomes Domain produced statistically significant differences. In each, professional/technical-serving and combined-serving stakeholders rated the outcomes significantly higher than did lower division transferserving stakeholders. It is of interest that "students achieve an employment upgrade in their current field of work" was rated more important by developmental-serving stakeholders $(\underline{M}=3.17)$ than by any other group. The outcome "students obtain a job in the field studied at scc" was the outcome for which the most significant differences were found. In fact, significant differences were found between all groups for this outcome. The relatively low ratings that lower division transfer-serving stakeholders (each less than $\underline{M}=2.60$ ) gave these employment outcomes are noteworthy. Perhaps these stakeholders do not believe that the curricula they teach have direct applications to employment; perhaps they view most of the students they teach as out of the labor force and, consequently, their employment as being irrelevant. Perhaps the low ratings simply reflect the dominance of other outcomes that are viewed as more important.

Only one of the outcomes in the Traditional college Outcomes Domain produced significant differences. This 
outcome was "students master course content." The professional/technical-serving stakeholders rated this outcome significantly higher than did combined-serving stakeholders. The researcher was unable to provide an interpretation for this finding.

No significant differences in the Developmental Outcomes Domain were found among the subgroups. This finding is important in that one might expect that the developmental-serving stakeholders would rate the outcomes in this domain significantly higher than the other subgroups. They did not. Two of the three outcomes were among the 10 outcomes rated most important by the group overall--"students master basic skills" and "students identify an educational/career goal." These findings suggest that the outcomes in the Developmental Domain are of universal concern to stakeholders regardless of the type of students served.

\section{Research Question 4}

Is it possible to predict which outcomes are valued most highly by stakeholders based on the type of students they serve?

"Type of student served most often" was the variable for which the most statistically significant differences were found. The researcher posited that a subset of outcome variables could be found that would distinguish stakeholders serving different student groups from each other, If such 
discriminating variables could be identified, they might provide additional information to help the researcher determine which outcomes were most relevant for stakeholders in the four subgroups. A discriminant function analysis produced three functions that were able to correctly predict in approximately 698 of all cases. The predictive ability for stakeholders serving lower division transfer students was the best with an $81 \%$ predictive capacity. Three variables--"students transfer and compete, students obtain $\mathrm{BA} / \mathrm{BS}$, and students obtain professional licensure/certification"--accounted for 758 of the variability between subgroups.

It is probable that these three items exhibited the most variability between groups because they represent outcomes that are either strongly perceived to be of critical importance to one or more groups while being equally as strongly perceived to be of little importance to the other groups. For instance, "transferring and competing" and "obtaining a BA/BS" is likely to be central to the expectations that lower division transfer stakeholders have for their students, but it is likely to be of almost no importance to developmental and professional/ . technical stakeholders. Conversely, obtaining professional certification (e.g., nursing license, aviation mechanic certification) is the critical factor determining employability in some professional/technical programs, but 
is most likely not associated with the mission of lower division transfer students.

Implications. Knowing that three outcome goals have the most power to discriminate between subgroups, particularly to predict stakeholders serving lower division transfer students, adds to the knowledge of how these groups differ. However, the results of this analysis has very limited practical utility in terms of informing practitioners about how an outcomes assessment program might be designed at sunrise community College.

\section{Research Question 5a}

Does the perceived importance of student outcome goals vary in relationship to professional role?

For the biographical variable "professional role," the researcher found only two outcomes out of the 23 for which significant differences existed and for which Scheffé multiple range test of differences identified subgroup differences. Table 37 displays these outcomes, organized by Effectiveness Domain.

For the outcome "students develop positive selfperceptions," support staff rated the outcome significantly higher than did teachers. It is of interest that teachers rated this outcome slightly lower than did administrators although a statistically significant difference did not exist. The elevated importance given this outcome by support staff group is likely explained by the fact that 
this group included counselors who are trained professionally to help clients improve self-esteem. It should be noted that all three groups rated this outcome as the highest.

Table 37

Student Outcome Goals for Which Differences Were Found: Professional Role

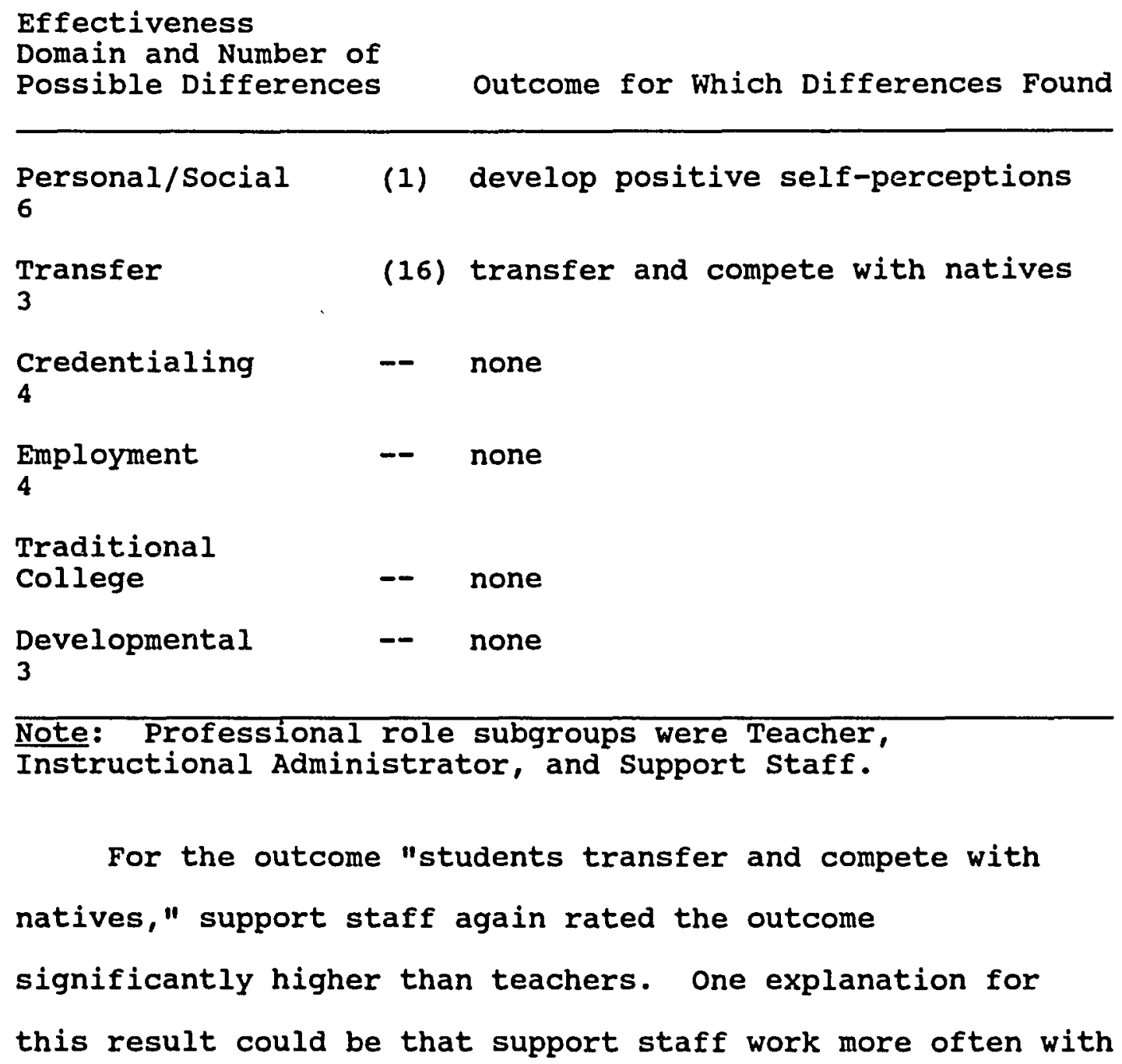


students who intend to transfer than with other students and, thus, may be more focused on these students.

Implications. It might have been expected that, based on their professional role, stakeholders would hold appreciably different views on what constitutes important outcomes for the students they serve. One might anticipate, for example, that instructional administrators would be more concerned than teachers that students achieve in the credentialing outcome Domain since these are highly visible measures of achievement. One might have expected that teachers would perceive outcomes in the Traditional college outcomes Domain, such as completing courses or mastering course content, as more important than support staff since these are outcomes that directly relate to their daily activities in the classroom. However, significant differences were not found, implying that, with the exception of the two outcomes discussed above, general consensus regarding the importance of the various outcomes existed at the college among these three groups. This consensus among individuals performing varying roles bodes well for Scc's effort to develop an outcomes assessment program. It suggests that a potentially problematic source of conflict does not exist, and agreement about what constitutes important goals for students probably will not be complicated by differing values among the professional roles at the college. 


\section{Research Question 5b}

Does the perceived importance of student outcome goals vary in relationship to the number of years worked in a community college?

For the demographic variable "number of years worked in a community college," the researcher found only three outcomes out of the 23 for which significant differences existed and for which the scheffe multiple range test of differences was able to identify the groups between which the differences occurred. Table 38 displays these outcomes, organized by effectiveness domain.

For each of the three outcomes for which statistically significant differences were found, the subgroup who had worked 10 years or less rated the outcome significantly higher than the subgroup who had worked 11 to 20 years. It should be noted that for the outcome "students master basic skills," which was ranked fourth most important by the whole group, the means for each subgroup was above a 3.5 , indicating a high level of importance for all three stakeholder groups.

It is difficult to speculate why stakeholders who had worked for community colleges the least number of years would be most like stakeholders who had worked the most number of years in their response to these three outcomes' importance. Perhaps analyzing these groups at smaller levels of aggregation (for example, in increments of five 
years) would produce results that are more meaningful. Once again, the high level of agreement among these groups in their values regarding which outcomes constitute important goals for students suggests that disagreement among groups will not constitute a source of conflict in SCC's effort to develop an outcomes assessment program.

Table 38

Student Outcome Goals for Which Differences Were Found: Number of Years Worked in Community Colleges

Effectiveness Domain and Number of Possible Differences Outcome for Which Differences Found

\begin{tabular}{|c|c|c|}
\hline $\begin{array}{l}\text { Personal/Social } \\
6\end{array}$ & -- & none \\
\hline $\begin{array}{l}\text { Transfer } \\
3\end{array}$ & -- & none \\
\hline $\begin{array}{l}\text { Credentialing } \\
4\end{array}$ & $(18)$ & $\begin{array}{l}\text { obtain licensure or certification } \\
\text { from professional organization }\end{array}$ \\
\hline & $(21)$ & get 1 - or 2-year certificate \\
\hline $\begin{array}{l}\text { Employment } \\
4\end{array}$ & -- & none \\
\hline $\begin{array}{l}\text { Traditional } \\
\text { College } \\
3\end{array}$ & - & none \\
\hline $\begin{array}{l}\text { Developmental } \\
3\end{array}$ & $(4)$ & master basic skills \\
\hline
\end{tabular}


Implications. If a large number of statistically significant differences had been found between these groups, the college would have been advised to address the differences as part of the process of developing an outcomes assessment program. The fact that few differences were found is additional evidence that consensus exists regarding the outcome goals the stakeholders value.

\section{Research Question $5 \mathrm{c}$}

Does the perceived importance of the student outcome goals vary in relationship to the number of years worked at scc?

For the demographic "number of years worked at sunrise Community college," the researcher found only one outcome out of the 23 for which significant differences existed between groups and for which the groups between which the difference existed could be identified using the Scheffé multiple range test of differences. This outcome was placed on the Effectiveness Domain under the Personal/Social Outcomes Domain.

For this outcome, the subgroup which had worked 10 years or less rated the outcome significantly higher than the subgroup who had worked 11 to 20 years. Even though there were statistically significant differences between the means for these two groups, a cautionary note again should be made--the means for each subgroup were above a 3.5, 
indicating a high level of importance for all three stakeholder groups.

Again, it is difficult to speculate why stakeholders who had worked at the college the least number of years would be most like stakeholders who had worked the most number of years in their perception to this outcomes' importance. As with the previous research question, meaningful differences may have been found if the data had been aggregated in 5 rather than 10 year periods. Table 39 displays the items for which differences were found.

Implications. Again, the lack of meaningful differences supports the assertion that consensus among the members in the sample exists.

\section{Research Question $5 \mathrm{~d}$}

Does the perceived importance of the student outcome goals vary in relationship to campus assignment?

During the focus group research which was conducted to develop the survey instrument, the researcher observed that staff at the four campuses often commented that meaningful differences existed among the campuses in terms of the students served, the characteristics of the faculty, and the general atmosphere. 
Table 39

Student Outcome Goals for Which Differences

Were Found: Number of Years

Worked at SCC

Effectiveness

Domain and Number of Possible Differences
Outcome for Which Differences Found

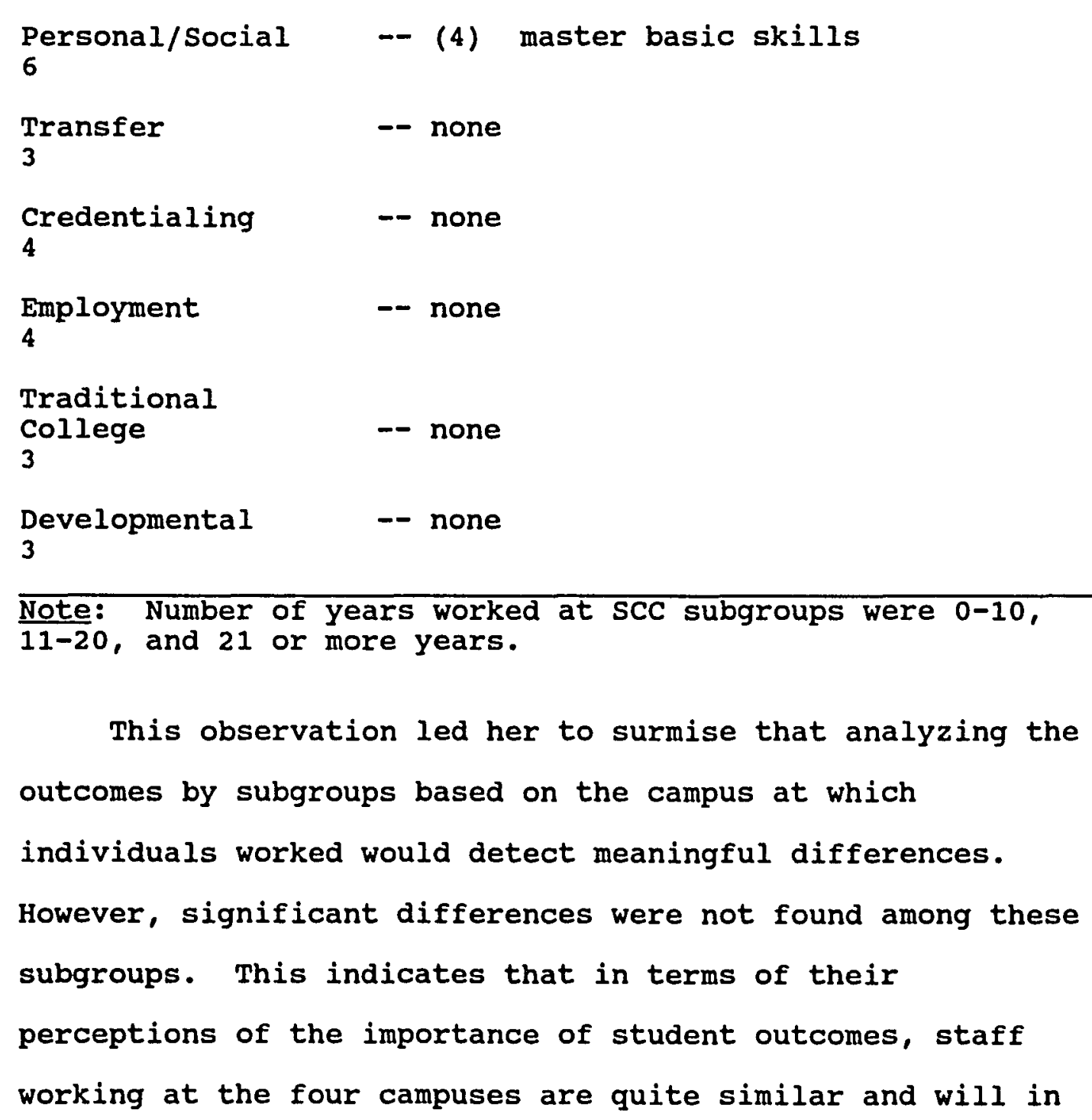

This observation led her to surmise that analyzing the outcomes by subgroups based on the campus at which individuals worked would detect meaningful differences. However, significant differences were not found among these subgroups. This indicates that in terms of their perceptions of the importance of student outcomes, staff working at the four campuses are quite similar and will in 
all likelihood agree on the fundamental question of what outcomes should be included in an assessment program.

\section{Research Question $5 e$}

Does the perceived importance of student outcome goals vary in relationship to gender?

As displayed in Table 40 The research found only two outcomes for which significant differences existed based on the gender of the respondents.l First, for the item "students develop positive self-perceptions," females rated the outcome significantly more important than men, although both rated the outcome above a 3.5. It is noteworthy that this outcomes was rated most important by the group as a whole. Second, females rated "students develop values free of ethnic, cultural, and gender bias" significantly higher than men. It is of interest that the outcomes that the two gender groups significantly differed on are in the affective Personal/Social Domain.

Implications. As with the variables professional role, years worked at a community college, years worked at sunrise Community college, and campus location, analysis of this variable produced very few significant differences. Male and female stakeholders rated almost all student outcomes at the same level of importance. I Once more, the findings support the idea that there is little disagreement among stakeholders regarding the importance of student outcomes. 
Table 40

student Outcone Goals for Which Differences

Were Found: Gender

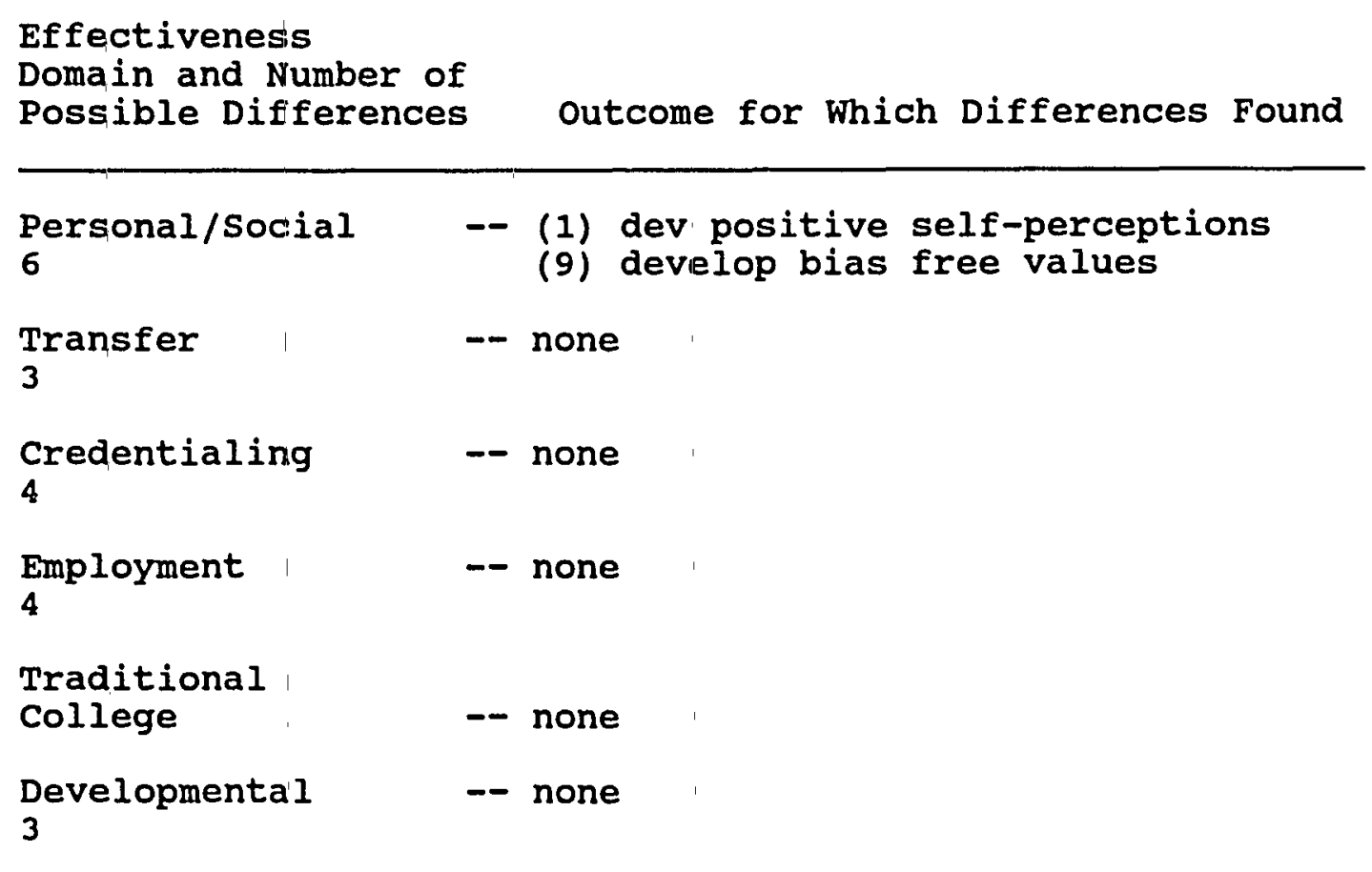

\section{Measuring the Foundation Skills-- Recommendations}

The author recommends that scc include the seven foundation outcomes in its assessment program. This recommendation is tempered by the caveat that current measurement technologies in these domains, particularly outcome goals in the affective-behavioral and affectivepsychological domains, are imperfect at best. This section discusses issues related to the measurement problems and 
suggests approaches that SCC could take to develop effective measurement of the foundation outcomes.

Astin (1991) asserts that for the purposes of outcomes assessment a specific affective-behavioral or affectivepsychological trait can be assessed using a single item rather than a scale made up of multiple items. He claims, "Since we are normally interested in assessing student outcomes using groups of students who have been exposed to particular educational programs, we have the luxury of being able to study a wide range of outcomes using individual items with the results aggregated across groups of students" (p. 59). One key to reliable measurement in this type of assessment is ensuring that a large enough sample of students is surveyed. Personal values, such as appreciating learning, eschewing ethnic, cultural, and gender bias, and appreciating the inter-relatedness of our global society are all values that lend themselves to single item assessment. Astin suggests using a measurement scale which calls for each student to select the importance of the value outcome to herself (very important, somewhat important, not very important).

For measuring self-concept, Astin (1991) suggests listing a set of self-descriptive traits. These traits would in effect be the entities that make up positive selfconcept, such as, perceived popularity, assurity of academic, social, or economic ability, and ability to cope. 
Students could be asked to rate themselves on each trait, either by choosing in absolute terms how they perceive themselves (very descriptive, somewhat descriptive), in terms of frequency (always feel . . , usually feel .|. ., seldom feel . . , never feel . . .), or in normative terms in relationship to their peers (above average, average, below average).

of course, self-reporting of affective-cognitive or affective-behavioral outcomes can be risky because people are not always honest in their responses. In order to address this possibility, Grandy (1988, p. 226) suggests that "unobtrusive measures" be constructed. By unobtrusive measures, she means behaviors or evidence of behaviors that are observed and from which the observer can infer the existence of the trait. Unobtrusive measures would be used in conjunction with self-reporting and would constitute a secondary measure of the trait. She says, "Devising unobtrusive measures can be a creative challenge . . . [It is] theoretically appealing, but hard to translate into practice" (p. 144).

It may be quite possible, however, for instructional stakeholders at SCC to design unobtrusive measures for the outcomes: (a) developing positive perception of self, (b) developing positive behaviors, and (c) developing values free of ethnic, cultural, and gender bias. Using an unobtrusive measure does not necessarily require that 
individual students be observed. Rather, evidence of behavior by groups of students can be observed. For example, the presence or absence of bias free values for the group can be measured by counting the number of instances of hate-graffiti present on a campus (and usually recorded by college security) and comparing the number over time.

If SCC chooses not to design its own assessment tools to measure affective-cognitive and affective-behavioral outcomes, commercially produced instruments are available. Grandy (1988) discusses in detail the issues, such as construct validity, that a college should consider in selecting a ready-made instrument, and she discusses the utility and limitations of a number of specific instruments. To measure the basic skills in reading, writing, math and language proficiency, the fourth highest rated outcome, scc can employ commercially available instruments, develop home-grown assessment tools, or use a combination of both approaches. Krosteng and Pike (1991) report that many institutions find it preferable to combine cognitive measures like standardized or locally written examinations with alternative methods such as portfolio analysis and competency demonstrations. The student outcomes Inventory Questionnaire did not specify precisely what knowledge and abilities constituted "a basic level of skills"; therefore, the first task of the college would be to develop an explicit definition of basic skills. once this is achieved, 
the choice of assessment methods could be made. If the speculation made by the author is correct--that is, mastering a basic level of reading, writing, math and English language skills is perceived as highly important by SCC stakeholders because they work with large numbers of students who do not have these skills--then assessment of these skills is imperative. Assessment should be performed when students are either in mid-program or when they leave the college.

SCC is currently using the ACT ASSET to test for basic skills as students enter the institution. ASSET was designed and is used solely for placement purposes. One option the college should explore is whether the results of the ASSET could be used in some way in developing a pretest/post test assessment of developmental skills. While the college would not find it feasible to post test all students, it could administer a post test to a representative sample of students in a variety of programs offered at scc.

\section{Limitations}

This study has three major limitations. First, it was conducted at a single institution, and, consequently, the findings cannot be generalized to other institutions. However, the strong agreement found across different campuses of the institution gives some promise to the broader generalizability of findings. Another limitation is 
that the instructional stakeholders in the sample were only full-time staff. Over $50 \%$ of the instructional staff at the college was part-time, and their exclusion from the study constitutes an important segment of stakeholders whose point of view was not represented. The rationale for excluding part-time stakeholders was that policy at the college is largely developed by full-time staff; however, this parttime group delivers educational programs to many scc students, and their selection of goals for students has an appreciable impact on what students achieve. Finally, the students themselves are important stakeholders whose point of view is missing from the study. As partners in the educational process, the outcomes students value as most important must be considered.

Second, the instrument has several limitations. The scale, a four-point Likert-like scale, would have captured the differences among respondents more distinctly if it had been a 7- or 10-point scale. The outcomes included in the student Outcome Goals Inventory were selected using focus group research with the sample population. As a result, the inventory items constituted outcomes valued by at least some off the sample stakeholders. Using a 7- or 10-point scale would have maximized the differences between groups more effectively than did the 4-point scale.

Third, the researcher believes the level of education off the respondent may be significantly related to his or her 
values related to outcome goals. This may be especially true in regards to items in the Transfer outcomes Domain. Failure to include this variable is a limitation of the study.

\section{Recommendations for Further study}

The researcher recommends four areas for further study. First, the researcher recommends that other colleges replicate the study. Comparisons should be made between the results found at $\mathrm{SCC}$ and those that would be found at other institutions. It can be argued that since SCC is a large college with separate campuses where few significant differences among. valued outcomes were found across these campuses, that findings may generalize to other colleges. However, replication would allow for comparison of results at distinctly different institutions, thereby increasing the confidence with which generalizations could be made.

The researcher believes that the process of this study --using focus groups to develop the instrument, conducting the survey, and presenting the results to groups of stakeholders for interpretation--was beneficial to the college. The process provided a forum for teachers, administrators, and support staff to think about and discuss issues related to outcomes assessment. This dialogue increased their knowledge of the issues involved in outcomes assessment. It also helped them focus on identifying which 
outcomes were most important for their students. This opportunity for reflection is an important first step to initiating the change effort known as outcomes assessment. Second, students' perceptions about the outcomes that are most important to them should be studied. Students, of course, are critical stakeholders in the educational process. The researcher recommends that a focus group process, similar to the one that was used successfully in this study, be used to create an instrument. It would be an error simply to administer the student outcome Goals Questionnaire to students since there may be important outcomes that should be added to the instrument. A study of student perceptions may reveal consensus with the goals found to be important to teachers, administrators, and support staff. But it may reveal important differences, too. The organizational change literature suggests that these stakeholders should not be left out of the process of identifying outcomes to include in an outcomes assessment program.

Third, the study should be replicated with part-time faculty at the institution. Since about half of all courses at SCC are taught by part-time faculty, the perceptions of these important stakeholders should be studied.

Fourth, the researcher recommends that the college study in more detail how instructional stakeholders define the foundation skills, such as basic skills and positive 
behaviors. This area of study could provide information that would aid in articulating precise outcomes for assessment and determining ways to measure these outcomes.

\section{Summary}

The research found that there is a set of foundation outcomes that are most highly valued by all groups of instructional stakeholders. Faculty, administrators, and support staff may share the perception that students must achieve the foundation outcomes before they can engage successfully in the college's traditional education programs. These foundation skills can be thought of as "enablers." They enable students to accomplish other outcomes including transfer, credentialing, and employment outcomes. For the most: part, the foundation skills are not included in external mandates for outcomes assessment. External mandates typically focus on the more easily measured credentialing, transfer, and employment outcomes. This dichotomy between what internal stakeholders value and what external stakeholders requilre colleges to report is problematic. On the one hand, $\mathbb{E}$ SCC develops an assessment program that focuses only on credentialing, transfer, and employment outcomes, it will beloverlooking the outcomes most valued by its teachers, administrators, and support staff. The tail, in effect, would be wagging the dog. on the other hand, if the college decides to assess the highly 
valued foundation outcomes, it would face formidable measurement problems. By assessing the foundation outcomes, however, the college would produce outcomes information that would be of genuine interest and value to all stakeholders. The literature related to organizational change, strategic planning, and program evaluation stresses the importance of adopting organizational goals that are meaningful for the individuals charged with carrying out those goals. This research has clearly identified the outcome goals that sCC instructional stakeholders believe to be most important for their students. It is likely that most stakeholders already are dedicating considerable effort to effecting these outcomes. It behooves the college, then, to assess the foundation outcomes. 


\section{REFERENCES}

Alexander, B., Taylor, K, Karnitz, C., \& Flermoen, C. (1990). Student outcomes pilot project: How to do it manual. Minneapolis, MN: North Hennepin Community College. (ERIC Document No. ED 317 245)

Alfred, R. L. (1986). Measuring student outcomes through the associate degree. Los Angeles, CA: Educational Resources Information Center.

Altieri, G. (1990). A structural model for student outcomes assessment programs in community colleges. Community College Review, 17(4), 15-21.

American Association of Community and Junior Colleges. (1988). Building communities: A vision for a new century. Washington, DC: American Association of Community and Junior colleges.

Argyris, c. (1970). Intervention theory and methods: A behavioral science view. Reading: Addison-Wesley.

Association of American Colleges. (1985). Integrity in the college curriculum: Report to the academic community. Washington, DC: Association of American Colleges.

Astin, A. W. (1970). Measuring student outputs in higher education: Outputs of higher education. Boulder, Co: Western Interstate Commission for Higher Education.

Astin, A. W. (1974). Measuring the outcomes of higher education. In H. R. Bowen (Ed.), Evaluating institutions for accountability. New directions for institutional research: Vol. 1 (pp. 23-46). San Francisco: Jossey-Bass.

Astin, A. W. (1982, July 28). Point of view: Let's try a "value-added" approach to testing. Chronicle of Higher Education, 24 (22), 40 .

Astin, A. W. (1985). Achieving educational excellence. San Francisco: Jossey-Bass.

Astin, A. W. (1991). Assessment for excellence: The philosophy and practice of assessment and evaluation in higher education. New York: McMillan. 
Baldridge, H. V., \& Deal, T. (Eds.). (1983). The dynamics of organizational change in education. Berkeley, CA: McCutchan.

Banta, T. W. (1988). Assessment as an instrument of state funding policy. In T. W. Banta (Ed.), Implementing outcomes assessment: Promise and peril. New directions for institutional research: Vol. 59 (pp. 81-94). San Francisco: Jossey-Bass.

Beckhard, R. (1969). organization development: Strategies and models. Reading: Addison-Wesley.

Bennett, W. J. (1984). To reclaim a legacy: Report on the humanities in higher education. Washington, DC:

National Endowment for the Humanities.

Bowles, S., \& Gintis, H. (1976). Schooling in capitalist America. New York: Basic Books.

Boyer, C. M., Ewell, P. T., Finney, J. E., \& Mingle, J. R. (1987). Assessment and outcomes measurement: A view from the states. American Association of Higher Education Bulletin, 39(7), 8-12.

Bradley, J., Draper, G., \& Pike, G. (1993, January/ February). Assessment Measures. Assessment Update, ${ }_{\text {, }}$ p. 10 .

Braskamp, L. A., \& Krug, S. (1989). High investment organizations: A source book. Champaign, IL: MetriTech.

Brint, S., \& Karabel, J. (1989) . The diverted dream: Community colleges and the promise of educational opportunity in America, 1900-1985. New York: Oxford University Press.

California Community Colleges AB 1725 Accountability Task Force. (1990). California community college accountability model. Sacramento: office of the Chancellor. (ERIC Document No. ED 317 252)

Chaffee, E. E. (1989, March). Key organizational issues that affect the pursuit and assessment of quality. Paper presented at the National Advisory Panel Meeting of the National Center for $\mid$ Postsecondary Governance and Finance, San Francisco, CA.

clark, B. (1960, May). The cooling out function in higher education. American Journal of Sociology, 65, 569-576. 
Clark, B. (1975). The organizational saga in higher education. In J. V. Baldridge \& T. Deal (Eds.), Managing change in educational organizations (pp. 98-107). Berkeley: McCutchan.

clark, B. (1980). The "cooling out" function revisited. In G. Vaughn (Ed.), Questioning the community college role. New directions for community colleges (pp. 15-31). San Francisco: Jossey-Bass.

Cohen, M., \& March, J. (1986). Leadership and ambiguity: The American college president. New York: McGraw Hill.

Cope, R. G. (1985). A contextual model to encompass the strategic planning concept: introducing a newer paradigm. Planning for Higher Education, 13(2), 13-20.

Corrallo, S. (1993, May/June). National assessment of college student learning: A status report. Assessment Update, 3, 5-7.

Cowart, s. C. (1990). Project cooperation: A survey on using student outcomes measures to assist institutional effectiveness, final report. Washington, DC: American Association of Community and Junior Colleges.

Cronbach, L. J. (1982). Designing evaluations of educational and social programs. San Francisco: Jossey-Bass.

Cross, K. P. (1990, July). Transfer: Major mission of community colleges. Paper presented at the Second Annual International Conference on Leadership Development of the League for Innovation in the Community College, San Francisco, CA.

Daughdrill, J. H., Jr. (1988, January 27). Point of view: Assessment is doing more for higher education than any other development in recent history. Chronicle of Higher Education, 34(20), A52.

Edmunds, P. A., Gwynn, V. N., Hanieski, D. H. , \& Herder, D. M. (1990). Instructional quality assurance at Lansing Community College. Lansing, MI: Lansing Community College. (ERIC Document No. ED 331 121)

E1-Khawas, E. (1987). Campus trends, 1987. Washington, DC: American Council on Education.

El-Khawas, E. (1988). Campus trends, 1988. Washington, DC: American Council on Education. 
El-Khawas, E. (1989) - Campus trends, 1989. Washington, DC: American Council on Education.

El-Khawas, E. (1990) . Campus trends, 1990. Washington, DC: American Council on Education.

El-Khawas, E. (1991). Campus trends, 1991. Washington, DC: American Council on Education.

Elman, S. E., Lynton, E. A. \& McCormack, J. (1985, October). Assessment in professional education. Paper presented at the National Conference on Assessment in Higher Education, University of South Carolina, Columbia, South Carolina.

Erwin, T. D. (1991). Assessing student learning and development: A quide to the principles, goals, and methods of determining college outcomes. San Francisco: Jossey-Bass.

Ewell, P. T. (1983). Information on student outcomes: How to get it and how to use it. Boulder, Co: National Center for Higher Education Management Systems.

Ewell, P. T. (1984). The self-regarding institution: Information for excellence. Boulder, CO: National Center for Higher Education Management Systems.

Ewell, P. T. (Ed.). (1985). Assessing educational outcomes. New directions for institutional research: Vol. 47. San Francisco: Jossey-Bass.

Ewell, P. T. (1986). The state role in assessing college outcomes: Policy choices and probable impacts. Time for results: The governors' 1991 report on education-supporting works by the task force on college quality. Washington, DC: National Governors' Association.

Ewell, P. T. (1987a). Assessment, accountability, and improvement: Managing the contradiction. Paper prepared for the American Association for Higher Education. Boulder, co: National Center for Higher Education Management Systems.

Ewell, P. T. (1987b). Establishing a campus based assessment program. In D. F. Halpern (Ed.), student outcomes assessment: What institutions stand to gain. New directions in higher education: Vol. 59 (pp. 9-24). San Francisco: Jossey-Bass. 
Ewell, P. T. (1992, July/August). Developing performance indicators for community colleges: Evidence from two states. Assessment Update, $\underline{4}, 10-14$.

Ewell, F. T., \& Lisensky, R. P. (1988). Assessing institutional effectiveness: Redirecting the self-study process. Washington, DC: Consortium for the Advancement of Private Higher Education.

Fincher, c. (1984). Educational quality and measured out.comes. Research in Higher Education, 20, 379-382.

French, W. L., Bell C. H. \& Zawacki, R. A. (Eds.) . (1989). organization development: Theory, practice and research. Homewood, IL: Richard D. Irwin.

Friedlander, F., \& Brown, L. D. (1974). Organization development. Annual Review of Psychology, 254, $313-341$.

Fullan, M. G. (1991). The new meaning of educational change. New York: Teachers College Press.

Gagne, R. M. (1977). The conditions of learning. New York: Holt, Rinehart and Winston.

Grandy, J. (198B). Assessing changes in student values. In C. Adelman (Ed.), Performance and judgment: Essays on principles and practice in the assessment of college student learning (pp, 217-233). Washington, DC: U.S. Department of Education.

Grossman, G. M. , \& Duncan, M. E. (1989). Indicators of institutional effectiveness: A quide for assessing twoyear colleges. Ohio State University, Columbus: National Alliance of Community and Technical Colleges.

Guba, E. G. (1959, May). The failure of educational evaluation. Educational Technology, 9, 29-38.

Guba, E. G., \& Lincoln, Y. S. (1981). Effective evaluation.| San Francisco: Jossey-Bass.

Guba, E. G., \& Lincoln, Y. S. (1989). Fourth generation evaluation. Newbury Park, CA: Sage.

Haas, R. M. (1980). Winning acceptance for institutional research and planning. In $\mathrm{P}$. Jedamus \& $M$. Peterson (Eds.), Improving academic management: A handbook of planning and institutional research (pp. 539-554). San Francisco: Jossey-Bass. 
Hackman, J. R. (1986). The psychology of self-management in organizations. In M. S. Pallack \& R. O. Perloff (Eds.), Psychology and work: Productivity, change, and employment (pp. 85-136). Washington, DC: American Psychological Association.

Halpern, D. F. (Ed.). (1987) . Student outcomes assessment: What institutions stand to gain. New Directions for Higher Education: Vol. 59. San Francisco: Jossey-Bass.

Hanson, G. (1988). Critical issues in the assessment of value added leducation. In T. W. Banta (Ed.), Implementing outcomes assessment: Promise and perils. New directions for institutional research: Vol. 59 (pp. 53-68). San Francisco: Jossey-Bass.

Heany, B. (1990). The assessment of educational outcomes. Office of Educational Research and Improvement, Washington, DC: U.S. Department of Education.

Henry, T. (1986). Needed: Comprehensive evaluation of education program effects. Community College Review, $\underline{14}(2), 46-52$.

Hoachlander, E. G., \& Rahn, M. L. (1992). Performance measures and standards for vodational education: 1991. Berkeley, CA: National Center for Research in Vocational Education, University of California at Berkeley.

Huberman, M. A. |(1983, November). | School improvement strategies that work: Some scenarios. Educational Leadership, $41(3), 23-27$.

Hudgins, J. I. (1990). Institutional effectiveness: Mastering the process before it masters you. Columbia, SC: Midlands Technical College. (ERIC Nocument No. ED 322 981)

Hutchings, P., \& Marchese, T. (1990). Watching assessment: Questions, stories, prospects.l Change, 22 (5), 13-38.

Jacobi, M., Astin A. W., \& F Ayala, Jr. (1987) . College student outcomes assessment: A talent development perspective.' Washington, DC: ASHE.

Jaschik, S. (1985, September 18). Public universities trying tests and surveys to measure what students learn. The Chronicle of Higher Education, $31(3), 1$, 16. 
Jencks, C., \& Reisman, D. (1968). The academic revolution. New York: Doubleday.

Johnson, R., Prus, J., Andersen, C. J., \& El-Khawas, E. (1991). Assessing assessment (Higher Education Panel Report Number 79). Washington, DC: American Council on Education.

Karabel, J. (1972, May/June). The community college and social stratification: Submerged class conflict in American Higher Education. Harvard Educational Review, 42, 521-562.

Karabel, J. (1974). Protecting the portals: class and the community college. Social Policy, $\underline{5}(3), 12-18$.

Karabel J. (1980). Community colleges and social stratification. Harvard Educational Review, 50, 332-360.

Keller, G. (1982). Academic strategy: The management revolution in American higher education. Baltimore: Johns Hopkins University Press.

Kinnick, M. K. (1985). Increasing the use of student outcomes information. In P. T. Ewell (Ed.), Assessing educational outcomes. New directions in institutional research: Vol. 47 (pp. 93-109). San Francisco: JosseyBass.

Kinnick, M. K., \& Walleri, R. D. (1991). Assessment of behavioral change and performance. In J. 0 . Nichols (Ed.), A practitioner's handbook for institutional effectiveness and student outcomes assessment implementation (pp. 104-129). New York: Agathon Press.

Kinnick, M., Westine, J., \& Kempner, K. (1988). Beyond front door access: Attaining the bachelor's degree. Research in Higher Education, 29, 299-318.

Kotler, P., \& Murphy, P. E. (1981). Strategic planning for higher education. Journal of Higher Education, 52, $471-489$.

Kreider, P. E., \& Walleri, R. D. (1988). Seizing the agenda: Institutional effectiveness and student outcomes for community colleges. Community college Review, 16(2), 44-50. 
Krosteng, M. V., \& Pike G. R. (1991). Cognitive assessment instruments: Availability and utilization. In J. 0 . Nichols (Ed.), A practitioner's handbook for institutional effectiveness and student outcomes assessment implementation (pp. 76-103). New York: Agathon Press.

Krueger, R. A. (1988). Focus groups: A practical quide for applied research. Newbury Park, CA: Sage.

Lawler, E. E. (1986). High involvement management: Participative strategies for improving organizational performance. San Francisco: Jossey-Bass.

League of Women Voters. (1993). A primer on Oregon's Educational Reform Act. Salem: Author.

Legge, K. (1984). Evaluating planned organizational change. Orlando, FL: Academic Publishing.

Lenning, 0. T. (1977) . Previous attempts to "structure" educational outcomes and outcome-related concepts: $A$ compilation and review of the literature. Boulder, co: NCHEMS.

Lenning, O. T., Lee, Y. S., Micek, S. S., \& Service A. L. (1977). A structure for the outcomes of postsecondary education. Boulder, Co: National Center for Higher Education Management Systems.

Lincoln, Y. S., \& Guba E. G. (1985) . Naturalistic inquiry. Beverly Hills CA: Sage.

MacDonald, J. B. (1974). An evaluation of evaluation. Urban Review, I(1), 3-14.

MacDonald, J. B. (1976). Evaluation and the control of education. In D. Tawney (Ed.), Curriculum evaluation today: Trends and implications (pp. 3-14). Schools Council Research studies. London: MacMillan.

Madaus, G. F., Stufflebeam, D. L., \& Scriven, M. (1983). Program evaluation: A historical overview. In G. F. Madaus, M. Scriven, \& D. L. Stufflebeam (Eds.), Evaluation models: Viewpoints on educational and human services evaluation (pp. 3-23). Boston: KluwerNijhoff.

Marris, P. (1975). Loss and change. New York: Doubleday. 
McClenney, B. N., \& Chaffee, E. E. (Eds.). (1985). Integrating academic planning and budgeting. New directions for community colleges: Vol. 50. San Francisco: Jossey-Bass.

McGrath, D., \& Spear, M. (1991). The academic crisis in the community college. New York: State University of New York.

McGregor, D. (1960). The human side of enterprise. New York: McGraw Hill.

Miles, M. B. (1966, August). Data feedback and organization change in a school system. Paper presented at the American Sociological Association Meeting, San Francisco, CA.

Morgan, D. I. (1988). Focus qroups as qualitative research. Newbury Park, CA: Sage.

Mortimer, K. P. \& Mcconnell, T. R. (1978). Sharing authority effectively. San Francisco: Jossey-Bass.

Nasaw, D. (1979). Schooled to order: A social history of public schooling in the United States. New York: oxford University Press.

National Center for Research in Vocational Education. (1993). Accountability for vocational education: A practitioner's quide. Berkeley, CA: University of California.

National Governors' Association. (1986). Time for results: The governors' 1991 report on education. Washington, DC: National Governors' Association.

National Institute of Education. (1984). Involvement in learning: Realizing the potential of American higher education. Washington, DC: U.S. Government Printing office.

Nichols, J. O. (1991). A practitioner's handbook for institutional effectiveness and student outcomes assessment implementation. New York: Agathon Press

Northern Virginia Community College. (1992). Program and discipline evaluation manual: A plan for ongoing assessment of the effectiveness of educational programs and disciplines. Annandale, VA: Northern Virginia Community College. (ERIC Document No. ED 326 536) 
Northwest Association of Schools and Colleges, Commission on Colleges. (1992). Accreditation handbook. Seattle, WA: Northwest Association of Schools and Colleges.

Norusis, M. J. (1992). SPSS/PC+ base system user's quide version 5.0. Chicago: SPSS.

Oakes, J. (1986). Educational indicators: A quide for policymakers. Madison: Center for Policy Research in Education.

Oregon Department of Education. (1993). Toward implementation of the oregon Educational Act for the 21st Century: Working designs for change. Salem: Author.

Oroman, M. (1985). Hudson county Community college: Guidelines for self-study. Jersey City, NJ: Hudson County Community College. (ERIC Document No. ED 317 244)

Pace, C. R. (1979). Measuring outcomes of college: Five years findings and recommendations for the future. San Francisco: Jossey-Bass.

Pace, C. R. (1985). Perspectives and problems in student outcomes research. In P. T. Ewell (Ed.), Assessing educational outcomes. New directions for institutional research: Vol. 47 (pp. 7-18). San Francisco: JosseyBass.

Parnell, D. (1994). Logolearning: Searching for meaning in education. Waco, TX: CORD.

Peterson, M. W. (1980). Analyzing alternative approaches to planning. Improving academic management: A handbook of planning and institutional research. San Francisco: Jossey-Bass.

Pincus, F. L. (1980). False promises of the community colleges: Class conflict and vocational education. Harvard Educational Review, 50, 332-360.

Richardson, R. C. (1988). Improving effectiveness through strategic planning. Community College Review, 15(4), 17-23.

Richardson, R. C., Fish, E. A., \& Okum, M. A. (1987). Literacy in the open access college. San Francisco: Jossey-Bass. 
Roaden, A. I., Aery, S., Ashworth, K, , Busselle, J., Carroll, R., Davies, G., Knorr, S., Matthews, D., Turner, E., \& Wallhaus, R. (1987). A statement of policy by the state higher education executive officers on program and institutional assessment. Denver: state Higher Education Executive officiers.

Roberts, K. J. (1986). Quantitative program evaluation criteria. Milwaukee, WI: Milwaukee Area Technical College. (ERIC Document No. ED 272 260)

Schmuck, R. A. (1988). The handbook of organization development in schools. Prospect Heights, IL: Waveland.

Schmuck, R., \& Miles, M. (1976). Organization development in schools. Palo Alto, CA: National Press Books.

Scriven, M. (1967) . The methodology of evaluation. In R. E. Stake (Ed.), Curriculum evaluation (pp. 143-157). American Educational Research Association Monograph Series on Evaluation, No 1. Chicago: Rand McNally.

Scriven, M. (1973). The methodology of evaluation. In B. R. Worthen \& J. R. Sanders (Eds.), Educational evaluation: Theory and practice (pp. 229-260). Belmont, CA: Wadsworth.

Scriven, M. (1974). Evaluation perspectives and procedures. In W. J. Popham (Ed.), Evaluation in education (pp. 1-93). Berkeley, CA: McCutchan.

Sergiovanni, T. J., Burlingame, M., Coombs, F. S., \& Thurston, P. W. (1992). Educational governance and administration. Boston: Allyn and Bacon.

Shine, E. H. (1965). Organizational psychology. Englewood cliffs, NJ: Prentice Hall.

Shirley, R. C., \& Volkwein, J. F. (1978). Establishing academic program priorities. The Journal of Higher Education, $49,472-488$.

Southern Association of Colleges and Schools, Commission on Colleges. (1985). Criteria for accreditation.

Atlanta, GA: Author.

Southern Association of Colleges and Schools, Commission on Colleges. (1987). Resource manual on institutional effectiveness. Atlanta, GA: Author. 
Southern Regional Education Board. (1985). Access to guality undergraduate education. Atlanta, GA: Author.

SPSS, Inc. (1992). Statistical Program for the Social Sciences 5.0 [computer program]. Chicago: SPSS.

Stewart, D. W., \& Shamdasani, P.।N. (1990). Focus qroups: Theory and practice. Newbury Park, CA: Sage.

Sunrise Community College. (1991a). Catalog: Fall term 1990 to summer term 1991. Fortland, OR: Author.

Sunrise Community College. (1991b). Factbook: 1989-90. Portland, OR: Author.

Suskie, I. A. (1989). Questionnaire Survey Research: What Works. Tallahassee, FL: AIR.

Toombs, W., \& Tierney, W. G. (1991). Meeting the mandate: Renewing the college and departmental curriculum. ASHE-ERIC Higher Education Report 6 . Washington, DC: George Washington University School of Education and Human Development.

Trachtenberg, S. J. (1978). Positioning for survival. Planning for Higher Education, 13(3), 1-3.

U.S. Department of Education. (1987). Secretary's procedures and criteria for recognition of accrediting agencies. Federal Reqister, 52(173), 33,906-33,913.

U.S. Department of Education. (1990a). Carl D. Perkins vocational and applied technology education act amendments for 1990. Federal Register, 55(240), $51,304-51,305$.

U.S. Department of Education. (1990b). The student rightto-know and campus security act. Federal Register, 57(133), 39,725-30,833.

U. S. Department of Education. (1992). National Education Goals Panel--The national education goals report: Building a nation of learners. Washington, DC: U.S. Government Printing office.

Walleri, R. D., \& Japely, S. (1986, May). Student intent, persistence and outcomes. Paper presented at the twenty-sixth annual forum of the Association for Institutional Research, orlando, Florida. 
Walleri, R. (1987). A longitudinal study of guided studies students. Paper presented at the Twenty-seventh Annual Forum of the Association for Institutional Research, Kansas City, Missouri.

Weis, L. (1985). Between two worlds: Black students in an urban community college. Boston: Routledge and Kegan Paul.

Weiss, H. (1984). Toward the future of stakeholder approaches in evaluation. In R. F. Connor, D. G. Altman, \& C. Jackson (Eds.), Evaluation studies review annual: Vol. 9 (pp. 255-268). Beverly Hills, CA: Sage.

Welker, W. F., \& Morgan, S. D. (1991). Moving beyond the literature on institutional effectiveness for community, junior and technical colleges. The consortium for institutional effectiveness and student success in the conmunity college: Membership resource packet. Gresham, OR:।Mt. Hood Community College.

Worthen, B. R. \& Sanders, J. R. (1987) . Educational evaluation: Alternative approaches and practical guidelines. New York: Longman.

Yost, M. (1991). Developing the expanded statement of institutional purpose. In J. O. Nichols (Ed.), A practitioner's handbook for institutional effectiveness and student outcomes assessment implementation (pp. 39-54). New York: Agathon Press.

Zwerling, L. S. (1976). Second best: The crisis in the community college. New York: McGraw Hill. 
APPENDIX A

STUDENT OUTCONE GOALS INVENTORY QUESTIONNAIRE AND COVER LETTER 
April 27, 1989

\section{Dear Colleague:}

The enclosed questionnaire is part of a research study being conducted by Institutional Research. The purpose of the study is to gain a better understanding of the kinds of student success PCC staff believe are most important for our students. In addition, it aims to determine what information about student success the staff would find most useful for improving our educational and support services to students.

The questionnaire was developed through a carefully planned dialogue with representative PCC staff members. Winter term, over fifty people from Cascade, Rock Creek, Sylvania and the Open Campus met in small groups to discuss their ideas about student success and information needs. These ideas were organized and transformed into the PCC Student Success Questionnaire.

Now, we hope to determine which of the many kinds of student success and possible information resources identified by the groups are most important to you. To help in this effort, please complete the enclosed questionnaire and retum it via campus mail:

BY: May 10, 1989

TO: Linda Gerber INSTITUTIONAL RESEARCH

RI B12

We would like to thank you in advance for completing this questionnaire. Your answers to the questions will remain confidential. If you have any questions, contact Linda at extension 2518.

Sincerely,

President

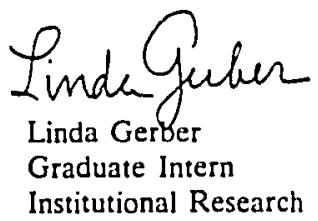




\section{Student Outcome Goals Inventory Survey Questionnaire}

1. At which SCC location do you currently work most often?

$\begin{array}{ll}-1 & \text { Riverview Campus } \\ -2 & \text { Meadowland Campus } \\ -3 & \text { Brooklyn Canpus } \\ -4 & \text { Extended Campus }\end{array}$

2. Which of the student group categories below best describes the students yith whom you work most often? (Check one.)

- 1 Students enrolled in technical or vocational programs

- 2 Students enrolled in developmental education, English as a Second Language, English as a Non-native Language, GED preparation or Adult Basic Education

3 Students enrolled in lower division transfer courses

- 4 Students in two or more of the above categories (You cannot identify only one group as "the one with whom you work most of ten.")

3. Which of the professional roles below best describes the work you do most often at SCC?

$\begin{array}{ll}-1 & \text { Advisor } \\ -2 & \text { Counselor } \\ -3 & \text { Teacher } \\ -4 & \text { Librarian } \\ -5 & \text { Adninistrator } \\ -6 & \text { Other Please describe }\end{array}$

4. How many years have you been working in a community college?

5. How many years have you been working at SCC?

6. What is your gender?

$\begin{array}{ll}-1 & \text { Female } \\ -2 & \text { Male }\end{array}$


Below is a list of statements most frequently used by SCC staff to define success for SCC students. Please circle the number that best describes how important you think each kind of success stated belOW is FOR THE STUDENTS WITH WHOM YOU WORK MOST OFTEN.

students have achleved educational success

Not

Important

\section{Mildly}

Importan

Moderately

Importan!

Very

when:

1. They develop the skilis to set educational and career goals for themselves.

2. They identify an educational or career goal relevant to their talents and abilities.

3. They achieve the educational goal (s) they have set for themselves at SCC.

4. They obtain a job related to the curriculum they studied at SCC

(regardless of program completion).

5. They are able to maintain the qualifications for the job they now hold by upgrading their skills/knowledge.

6. They achieve an employment upgrade in their current field of work.

7. They develop a positive perception of themselves (for example, selfesteem and self-confidence).

8. They develop values free of ethnic, cultural, and gender bias.

9. They understand the interrelatedness of our global society.

10. They develop positive behaviors (for example, initiative, honesty, and self-discipline).

11. They develop an intrinsic appreciation of learning.

12. They complete the courses for which they are enrolled at SCC.

13. They develop the skills and acquire the knowledge base to succeed in more advanced levels of courses at SCC. 


$\begin{array}{llll}\text { Not } & \text { Mildly } & \text { Moderately } & \text { Very } \\ \text { Important } & \text { Important } & \text { Important } & \text { Important }\end{array}$

14. They master a basic level of skills 1

15. They master course content at a

17. They obtain a high school diploma or 1 GED.

18. They obtain an associate degree.

19. They obtain a 1 or 2 year certificate from SCC.

20. they obtain certification or

21 They transfer to a four-year

23. they transfer to a four-year college 1

or university and are academically competitive with students who were lower division students at that institution. 


\section{APPENDIX B}

RESULTS OF ONE-WAY ANALYSIS OF VARIANCE AND $\underline{T}$ TEST FOR FACTORS 
Chart 1

Analysis of Variance for Factors between Groups

Based on the Type of student Served

\begin{tabular}{|c|c|c|c|c|c|c|}
\hline Factor & $\begin{array}{l}\text { Source of } \\
\text { Variation }\end{array}$ & $\begin{array}{l}\text { Sum of } \\
\text { Squares }\end{array}$ & $\mathrm{DF}$ & $\begin{array}{l}\text { Mean } \\
\text { Squares }\end{array}$ & $\mathbf{F}$ & $\begin{array}{l}\text { F } \\
\text { Prob }\end{array}$ \\
\hline $\begin{array}{l}\text { Factor 1: } \\
\text { Pers/social } \\
\text { development }\end{array}$ & $\begin{array}{l}\text { Between grps } \\
\text { within grps } \\
\text { Total }\end{array}$ & $\begin{array}{r}3.9402 \\
236.0598 \\
240.0000\end{array}$ & $\begin{array}{r}3 \\
237 \\
240\end{array}$ & $\begin{array}{r}1.3134 \\
.9960\end{array}$ & 1.3186 & .2690 \\
\hline $\begin{array}{l}\text { Factor 2: } \\
\text { Transfer } \\
\text { outcomes }\end{array}$ & $\begin{array}{l}\text { Between grps } \\
\text { within grps } \\
\text { Total }\end{array}$ & $\begin{array}{r}74.6583 \\
165.3417 \\
240.0000\end{array}$ & $\begin{array}{r}3 \\
237 \\
240\end{array}$ & $\begin{array}{r}24.8861 \\
.6976\end{array}$ & 35.6716 & .0000 \\
\hline $\begin{array}{l}\text { Factor 3: } \\
\text { Credentialing } \\
\text { outcomes }\end{array}$ & $\begin{array}{l}\text { Between grps } \\
\text { Within grps } \\
\text { Total }\end{array}$ & $\begin{array}{r}34.6387 \\
205.3613 \\
240.0000\end{array}$ & $\begin{array}{r}3 \\
237 \\
240\end{array}$ & $\begin{array}{r}11.5462 \\
.8665\end{array}$ & 13.3251 & .0000 \\
\hline $\begin{array}{l}\text { Factor 4: } \\
\text { Employment } \\
\text { outcomes }\end{array}$ & $\begin{array}{l}\text { Between grps } \\
\text { Within grps } \\
\text { Total }\end{array}$ & $\begin{array}{l}26.8787 \\
213.1213 \\
240.000\end{array}$ & $\begin{array}{r}3 \\
237 \\
240\end{array}$ & $\begin{array}{r}8.9596 \\
.8992\end{array}$ & 9.9634 & .0000 \\
\hline $\begin{array}{l}\text { Factor 5: } \\
\text { Trad. college } \\
\text { outcomes }\end{array}$ & $\begin{array}{l}\text { Between grps } \\
\text { within grps } \\
\text { Total }\end{array}$ & $\begin{array}{r}6.2206 \\
233.7794 \\
240.000\end{array}$ & $\begin{array}{r}3 \\
237 \\
240\end{array}$ & $\begin{array}{r}2.0735 \\
.9864\end{array}$ & 2.1021 & .1006 \\
\hline $\begin{array}{l}\text { Factor 6: } \\
\text { Developmental } \\
\text { outcomes }\end{array}$ & $\begin{array}{l}\text { Between grps } \\
\text { Within grps } \\
\text { Total }\end{array}$ & $\begin{array}{r}1.6378 \\
238.3622 \\
240.0000\end{array}$ & $\begin{array}{r}3 \\
237 \\
240\end{array}$ & $\begin{array}{r}.5459 \\
1.0057\end{array}$ & .5428 & .6534 \\
\hline
\end{tabular}


Chart 2

One-way Analysis of Variance for Factors between Groups Based on the Professional Role

\begin{tabular}{|c|c|c|c|c|c|c|}
\hline Factor & $\begin{array}{l}\text { Source of } \\
\text { Variation }\end{array}$ & $\begin{array}{l}\text { Sum of } \\
\text { Squares }\end{array}$ & ---- & $\begin{array}{l}- \\
\text { Mean } \\
\text { Squares }\end{array}$ & $\mathbf{F}$ & Prob \\
\hline $\begin{array}{l}\text { Factor 1: } \\
\text { Pers/social } \\
\text { development }\end{array}$ & $\begin{array}{l}\text { Between grps } \\
\text { Within grps } \\
\text { Total }\end{array}$ & $\begin{array}{r}2.8752 \\
212.3497 \\
215.2249\end{array}$ & $\begin{array}{r}2 \\
213 \\
215\end{array}$ & $\begin{array}{r}1.4376 \\
.9969\end{array}$ & 1.4420 & .2387 \\
\hline $\begin{array}{l}\text { Factor } 2: \\
\text { Transfer } \\
\text { outcomes }\end{array}$ & $\begin{array}{l}\text { Between grps } \\
\text { Within grps } \\
\text { Total }\end{array}$ & $\begin{array}{r}3.4074 \\
213.2066 \\
216.6140\end{array}$ & $\begin{array}{r}2 \\
213\end{array}$ & $\begin{array}{l}1.7037 \\
1.0010\end{array}$ & $\begin{array}{c}1.7021 \\
-\quad---\end{array}$ & .1848 \\
\hline $\begin{array}{l}\text { Factor } 3: \\
\text { Credentialing } \\
\text { outcomes }\end{array}$ & $\begin{array}{l}\text { Between grps } \\
\text { Within grps } \\
\text { Total }\end{array}$ & $\begin{array}{r}3.3060 \\
210.1715 \\
213.4774\end{array}$ & $\begin{array}{r}2 \\
213 \\
215\end{array}$ & $\begin{array}{r}1.6530 \\
.9867\end{array}$ & 1.6752 & .1897 \\
\hline $\begin{array}{l}\text { Factor } 4: \\
\text { Employment } \\
\text { outcomes }\end{array}$ & $\begin{array}{l}\text { Between grps } \\
\text { Within grps } \\
\text { Total }\end{array}$ & $\begin{array}{r}4.8546 \\
221.1258 \\
225.9804\end{array}$ & $\begin{array}{r}2 \\
213 \\
215\end{array}$ & $\begin{array}{l}2.4273 \\
1.0381\end{array}$ & 2.3381 & .0990 \\
\hline $\begin{array}{l}\text { Factor 5: } \\
\text { Trad. colliege } \\
\text { outcomes }\end{array}$ & $\begin{array}{l}\text { Between grps } \\
\text { Within grps } \\
\text { Total }\end{array}$ & $\begin{array}{r}5.2686 \\
216.0564 \\
221.3251\end{array}$ & $\begin{array}{r}2 \\
213 \\
215\end{array}$ & $\begin{array}{l}2.6343 \\
1.0143\end{array}$ & 2.5971 & .0769 \\
\hline $\begin{array}{l}\text { Factor 6: } \\
\text { Developmental } \\
\text { outcomes }\end{array}$ & $\begin{array}{l}\text { Between grps } \\
\text { within grps } \\
\text { Total }\end{array}$ & $\begin{array}{r}3.2382 \\
227.6853 \\
230.9235\end{array}$ & $\begin{array}{r}2 \\
213 \\
215\end{array}$ & $\begin{array}{l}1.6191 \\
1.0689\end{array}$ & 1.514 & .2222 \\
\hline
\end{tabular}


Chart 3

Analysis of Variance for Factors between Groups Based on the Number of Years Worked in Community College

\begin{tabular}{|c|c|c|c|c|c|c|}
\hline Factor & $\begin{array}{l}\text { Source of } \\
\text { Variation }\end{array}$ & $\begin{array}{l}\text { Sum of } \\
\text { Squares }\end{array}$ & DF & $\begin{array}{l}\text { Mean } \\
\text { Squares }\end{array}$ & $\mathbf{F}$ & Prob \\
\hline $\begin{array}{l}\text { Factor 1: } \\
\text { Pers/social } \\
\text { development }\end{array}$ & $\begin{array}{l}\text { Between grps } \\
\text { within grps } \\
\text { Total }\end{array}$ & $\begin{array}{r}5.0509 \\
233.6063 \\
238.6571\end{array}$ & $\begin{array}{r}2 \\
237 \\
239\end{array}$ & $\begin{array}{r}2.5254 \\
.9857\end{array}$ & 2.5621 & .0793 \\
\hline $\begin{array}{l}\text { Factor } \overline{2}: \\
\text { Transfer } \\
\text { outcomes }\end{array}$ & $\begin{array}{l}\text { Between grps } \\
\text { Within grps } \\
\text { Total }\end{array}$ & $\begin{array}{r}4.4766 \\
233.8356 \\
238.3121\end{array}$ & $\begin{array}{r}2 \\
237 \\
239\end{array}$ & $\begin{array}{r}2.2383 \\
.9866\end{array}$ & 2.2686 & .1057 \\
\hline $\begin{array}{l}\text { Factor } 3 \text { : } \\
\text { Credentialing } \\
\text { outcomes }\end{array}$ & $\begin{array}{l}\text { Between grps } \\
\text { Within grps } \\
\text { Total }\end{array}$ & $\begin{array}{r}11.7862 \\
228.2130 \\
239.9992\end{array}$ & $\begin{array}{r}2 \\
237 \\
239\end{array}$ & $\begin{array}{r}5.8931 \\
.9629\end{array}$ & 6.1200 & .0026 \\
\hline $\begin{array}{l}\text { Factor 4: } \\
\text { Employment } \\
\text { outcomes }\end{array}$ & $\begin{array}{l}\text { Between grps } \\
\text { Within grps } \\
\text { Total }\end{array}$ & $\begin{array}{r}3.0463 \\
235.9505 \\
238.9968\end{array}$ & $\begin{array}{r}2 \\
237 \\
239\end{array}$ & $\begin{array}{r}1.5231 \\
.9956\end{array}$ & 1.5299 & .2187 \\
\hline $\begin{array}{l}\text { Factor 5: } \\
\text { Trad. college } \\
\text { outcomes }\end{array}$ & $\begin{array}{l}\text { Between grps } \\
\text { Within grps } \\
\text { Total }\end{array}$ & $\begin{array}{r}.3395 \\
238.0174 \\
238.3569\end{array}$ & $\begin{array}{r}2 \\
237 \\
239\end{array}$ & $\begin{array}{r}.1697 \\
1.0043\end{array}$ & .1690 & .8446 \\
\hline $\begin{array}{l}\text { Factor } 6: \\
\text { Developmental } \\
\text { outcomes }\end{array}$ & $\begin{array}{l}\text { Between grps } \\
\text { within grps } \\
\text { Total }\end{array}$ & $\begin{array}{r}4.1563 \\
235.7128 \\
239.8690\end{array}$ & $\begin{array}{r}2 \\
237 \\
239\end{array}$ & $\begin{array}{r}2.0781 \\
.9946\end{array}$ & 2.0895 & .1260 \\
\hline
\end{tabular}


Chart 4

Analysis of Variance for Factors between Groups Based on the Number of Years Worked at SCC

\begin{tabular}{|c|c|c|c|c|c|c|}
\hline $\begin{array}{l}\text { Factor 1: } \\
\text { Pers/social } \\
\text { development }\end{array}$ & $\begin{array}{l}\text { Between grps } \\
\text { within grps } \\
\text { Total }\end{array}$ & $\begin{array}{r}4.0138 \\
235.6202 \\
239.6340\end{array}$ & $\begin{array}{r}2 \\
237 \\
239\end{array}$ & $\begin{array}{r}2.0069 \\
.9942\end{array}$ & 2.0187 & .1351 \\
\hline $\begin{array}{l}\text { Factor 2: } \\
\text { Transfer } \\
\text { outcomes }\end{array}$ & $\begin{array}{l}\text { Between grps } \\
\text { within grps } \\
\text { Total }\end{array}$ & $\begin{array}{r}4.9158 \\
234.8911 \\
239.8068\end{array}$ & $\begin{array}{r}2 \\
237 \\
239\end{array}$ & $\begin{array}{r}2.4579 \\
.9911\end{array}$ & 2.4799 & .0859 \\
\hline $\begin{array}{l}\text { Factor } 3: \\
\text { Credentialing } \\
\text { outcomes }\end{array}$ & $\begin{array}{l}\text { Between grps } \\
\text { within grps } \\
\text { Total }\end{array}$ & $\begin{array}{r}3.6622 \\
236.1164 \\
239.7786\end{array}$ & $\begin{array}{r}2 \\
237 \\
239\end{array}$ & $\begin{array}{r}1.8311 \\
.9963\end{array}$ & 1.8380 & .1614 \\
\hline $\begin{array}{l}\text { Factor 5: } \\
\text { Trad. college } \\
\text { outcomes }\end{array}$ & $\begin{array}{l}\text { Between grps } \\
\text { within grps } \\
\text { Total }\end{array}$ & $\begin{array}{r}5.0946 \\
234.7567 \\
239.8513\end{array}$ & $\begin{array}{r}2 \\
237 \\
239\end{array}$ & $\begin{array}{r}2.5473 \\
.9905\end{array}$ & 2.5716 & .0785 \\
\hline $\begin{array}{l}\text { Factor 6: } \\
\text { Developmental } \\
\text { outcomes }\end{array}$ & $\begin{array}{l}\text { Between grps } \\
\text { within grps } \\
\text { Total }\end{array}$ & $\begin{array}{r}6.0543 \\
233.2657 \\
239.3200\end{array}$ & $\begin{array}{r}2 \\
237 \\
239\end{array}$ & $\begin{array}{r}3.0271 \\
.9842\end{array}$ & 3.0756 & .0480 \\
\hline
\end{tabular}


Chart 5

Analysis of Variance for Factors between Groups Based on the Campus Location

\begin{tabular}{|c|c|c|c|c|c|c|}
\hline Factor & $\begin{array}{l}\text { Source of } \\
\text { Variation }\end{array}$ & $\begin{array}{l}\text { Sum of } \\
\text { Squares }\end{array}$ & $\mathrm{DF}$ & $\begin{array}{l}\text { Mean } \\
\text { Squares }\end{array}$ & $F$ & $\begin{array}{l}\text { F } \\
- \text { Prob }\end{array}$ \\
\hline $\begin{array}{l}\text { Factor 1: } \\
\text { Pers/social } \\
\text { development }\end{array}$ & $\begin{array}{l}\text { Between grps } \\
\text { Within grps } \\
\text { Total }\end{array}$ & $\begin{array}{r}.4299 \\
238.9823 \\
239.4122\end{array}$ & $\begin{array}{r}3 \\
235 \\
238\end{array}$ & $\begin{array}{r}.1433 \\
1.0169\end{array}$ & .1409 & .9354 \\
\hline $\begin{array}{l}\text { Factor 2: } \\
\text { Transfer } \\
\text { outcomes }\end{array}$ & $\begin{array}{l}\text { Between grps } \\
\text { within grps } \\
\text { Total }\end{array}$ & $\begin{array}{r}1.4807 \\
238.2616 \\
239.7423\end{array}$ & $\begin{array}{r}3 \\
235 \\
238\end{array}$ & $\begin{array}{r}.4936 \\
1.0139\end{array}$ & .4868 & .6918 \\
\hline $\begin{array}{l}\text { Factor } 3: \\
\text { Credentialing } \\
\text { outcomes }\end{array}$ & $\begin{array}{l}\text { Between grps } \\
\text { within grps } \\
\text { Total }\end{array}$ & $\begin{array}{r}2.2798 \\
237.1029 \\
239.3827\end{array}$ & $\begin{array}{r}3 \\
235\end{array}$ & $\begin{array}{r}.7599 \\
1.0089\end{array}$ & .7532 & .5215 \\
\hline $\begin{array}{l}\text { Factor 4: } \\
\text { Employment } \\
\text { outcomes }\end{array}$ & $\begin{array}{l}\text { Between grps } \\
\text { within grps } \\
\text { Total }\end{array}$ & $\begin{array}{r}1.4024 \\
238.1307 \\
239.5331\end{array}$ & $\begin{array}{r}3 \\
235 \\
238\end{array}$ & $\begin{array}{r}.4675 \\
1.0133\end{array}$ & .4613 & .7096 \\
\hline $\begin{array}{l}\text { Factor 5: } \\
\text { Trad. college } \\
\text { outcomes }\end{array}$ & $\begin{array}{l}\text { Between grps } \\
\text { Within grps } \\
\text { Total }\end{array}$ & $\begin{array}{r}1.5599 \\
235.0141 \\
239.5740\end{array}$ & $\begin{array}{r}3 \\
235 \\
238\end{array}$ & $\begin{array}{r}.5200 \\
1.0128\end{array}$ & .5134 & .6734 \\
\hline $\begin{array}{l}\text { Factor 6: } \\
\text { Developmental } \\
\text { outcomes }\end{array}$ & $\begin{array}{l}\text { Between grps } \\
\text { Within grps } \\
\text { Total }\end{array}$ & $\begin{array}{r}.7695 \\
239.2047 \\
239.9741\end{array}$ & $\begin{array}{r}3 \\
235 \\
238\end{array}$ & $\begin{array}{r}.2565 \\
1.0179\end{array}$ & .2520 & .8599 \\
\hline
\end{tabular}


Chart 6

T-Test Comparison of Means for Student outcome Goals Based on Gender

\begin{tabular}{|c|c|c|c|c|c|c|c|c|}
\hline Factor & $\begin{array}{l}\text { Fema } \\
\text { Regr } \\
\mathbf{n}\end{array}$ & $\frac{\text { Factor } \mathrm{Sc}}{\text { Mean }}$ & $\frac{\text { ore }}{(S D)}$ & $\begin{array}{l}\text { Male } \\
\text { Regl } \\
\text { n }\end{array}$ & - Factor & $\frac{\text { Score }}{\text { (SD) }}$ & $\begin{array}{l}t- \\
\text { value }\end{array}$ & $\begin{array}{l}2- \\
\text { tail } \\
\text { prob }\end{array}$ \\
\hline $\begin{array}{l}\text { Factor 1: } \\
\text { Pers/social } \\
\text { development }\end{array}$ & 118 & .1692 & .863 & 122 & -.1626 & 1.099 & .60 & .010 \\
\hline $\begin{array}{l}\text { Factor 2: } \\
\text { Transfer } \\
\text { outcomes }\end{array}$ & 118 & -.0745 & .945 & 122 & .0868 & 1.040 & -1.26 & .210 \\
\hline $\begin{array}{l}\text { Factor } 3: \\
\text { Credentialing } \\
\text { outcomes }\end{array}$ & 118 & -.0407 & .995 & 122 & .0314 & 1.008 & -.56 & .578 \\
\hline $\begin{array}{l}\text { Factor 4: } \\
\text { Employment } \\
\text { outcomes }\end{array}$ & 118 & .0214 & 1.058 & 122 & -.0228 & .948 & .34 & .733 \\
\hline $\begin{array}{l}\text { Factor } 5: \\
\text { Trad. college } \\
\text { outcomes }\end{array}$ & 118 & -.0779 & .949 & 122 & .0823 & 1.046 & .095 & \\
\hline $\begin{array}{l}\text { Factor } 6: \\
\text { Developmental } \\
\text { outcomes }\end{array}$ & 118 & -.0230 & 1.053 & 122 & .0124 & .949 & -.27 & .785 \\
\hline
\end{tabular}

